\title{
Phylogeny of wasps of the genus Mischocyttarus de Saussure (Hymenoptera, Vespidae, Polistinae)
}

\author{
Orlando Tobias Silveira
}

Coordenação de Zoologia; Museu Paraense Emílio Goeldi, MPEG/MCT; Av. Perimetral 1901, Terra Firme, 66077-530 Belém-PA, Brazil; Fone: 55 -91-3217-6115; orlando@ museu-goeldi.br

\begin{abstract}
Phylogeny of wasps of the genus Mischocyttarus de Saussure (Hymenoptera, Vespidae, Polistinae). A phylogenetic analysis is presented of subgenera and species-groups of Mischocyttarus de Saussure, the largest genus of social wasps. The analysis is based on 62 morphological and nest architecture characters, coded for 71 terminals representing much of the taxonomic diversity within the genus, plus three outgroup terminals representing other polistine tribes. The main conclusions about phylogenetic relationships within the genus are based on parsimony analysis under implied weights. Monophyly of Mischocyttarus is confirmed as well as that of most of the previously recognized subgenera: Mischocyttarus s. str., Clypeopolybia, Monogynoecus, Scytokeraia, Phi, Kappa, Megacanthopus and Omega sensu Richards (1978). Haplometrobius as conceived by Richards (1978) is not a monophyletic taxon, but some of its species-groups are monophyletic. The groups of $M$. artifex and $M$. cerberus are raised to subgenus level, and a new concept of Haplometrobius restricts it to the group of $M$. iheringi (the type species of this subgenus) in the sense of this work. The concept of subgenus Omega is widened to include the species-groups of M. surinamensis and M. prominulus. Besides the new subgeneric classification presented, limits and diagnoses of all species-groups of the subgenera Phi and Haplometrobius sensu Richards (1978) are discussed, and a new key for all subgenera and species-groups of Mischocyttarus is also presented.
\end{abstract}

KEYWORDS. Systematics; new classification; social wasps.

RESUMO. Filogenia das vespas do gênero Mischocyttarus de Saussure (Hymenoptera, Vespidae, Polistinae). O artigo apresenta um estudo filogenético dos subgêneros e grupos de espécies de Mischocyttarus de Saussure, o maior dos gêneros de vespas sociais. A análise é baseada em 62 caracteres morfológicos e de arquitetura de ninhos, codificados para 71 terminais representantes da diversidade taxonômica do gênero e mais três terminais correspondentes às outras três tribos de Polistinae. As conclusões principais sobre relações filogenéticas são extraídas de análises usando pesagem implícita de caracteres. O monofiletismo de Mischocyttarus é confirmado, assim como da maioria dos subgêneros previamente reconhecidos: Mischocyttarus s. str., Clypeopolybia, Monogynoecus, Scytokeraia, Phi, Kappa, Megacanthopus e Omega sensu Richards (1978). Haplometrobius tal como concebido por Richards (1978) não é um táxon monofilético, mas alguns de seus grupos de espécies são monofiléticos. Os grupos de $M$. artifex e $M$. cerberus são elevados à categoria de subgênero e um novo conceito mais restrito de Haplometrobius é adotado, circunscrito ao grupo de M. iheringi (a espécie tipo desse subgênero). O conceito do subgênero Omega é ampliado para incluir os grupos de espécies de M. surinamensis e $M$. prominulus. Além de uma nova classificação subgenérica, acompanhada de chave de identificação, discute-se também os limites e diagnoses de todos os grupos de espécies dos subgêneros Phi e Hamplometrobius sensu Richards (1978).

PALAVRAS-CHAVE. Sistemática; nova classificação; vespas sociais.

Mischocyttarus de Saussure (1853) is the single genus in Mischocyttarini, one of the four tribes recognized by Carpenter (1993) in the subfamily Polistinae of social wasps. The genus is the largest among social vespids with 245 species distributed in nine subgenera, being essentially a Neotropical taxon with a few species occurring north of Mexico (Carpenter \& Wenzel, 1988; Cooper, 1996a, 1996b, 1997a, 1997b, 1998a, 1998b; Raw, 1985, 1996; Richards, 1941, 1945, 1978; Silveira, 1998; Zikán, $1935,1949)$. It originally included only those species with a very long petiole between meso and metasoma, and whose nests typically have a circular comb suspended by a long thin central peduncle (de Saussure, 1853; Richards, 1978; Zikán, 1949). Other related morphotypes were initially assigned to Polybia Lepeletier (1836) or, some time later, to the newly created genera Megacanthopus Ducke (1904) and Monacanthocnemis Ducke (1905). Ducke (1913) himself recognized those two names as synonyms of Mischocyttarus, thus establishing the modern concept of the genus.

As currently understood, Mischocyttarus is recognizable by at least two characters that are exclusive to the genus. In adults, the internal and external lobes of the tarsal segments are asymmetrical, the former being longer. In addition, in mature larvae, the first abdominal sternum presents at least one forwardly directed, appendix-like process (Hunt, 1991; Kojima, 1998; Reid, 1942; Richards, 1978). The biology is similar to that found in species of Polistes Latreille (1802), with a dominance hierarchy being established among the females of a colony through physical attacks and oophagy. The nests normally consist of a single unenveloped comb, fastened to the substrate by a peduncle (Gadagkar, 1991; Jeanne, 1972, 1980; Richards, 1971; Wenzel, 1991, 1998).

The genus was revised by Richards (1945), Zikán (1949) 
and Richards (1978). The history of names applied to subgenera of Mischocyttarus by various authors is rather complicated, having been revised in part by Richards (1978) and Carpenter \& Day (1988). In his monograph about the Vespidae, Henri de Saussure (1854) used names derived from letters of the Greek alphabet to refer to groups of species (divisions) in the nominotypical subgenus of Polybia Lepeletier. Some of these divisions, corresponding in certain measure to groups of species of Mischocyttarus as currently conceived, received subsequently new names either at the genus or subgenus level, or simply attained formal recognition at the subgeneric level. Such are the cases of Monacanthocnemis Ducke (= Omega de Saussure, 1854), Monocyttarus Richards (1978) (= Phi de Saussure, 1854), and Kappa de Saussure (1854). In his book on the social wasps of the Americas, Richards (1978) followed the norm then in force of the International Code of Zoological Nomenclature $\left(2^{\text {nd }}\right.$ edition), which did not give formal status to names that had been originally used below the subgenus level. Richards therefore considered as valid the two names created by Ducke (1904, 1905), and attributed authorship of Kappa to Bequaert (1933) who had designated the type species of Kappa. In that same work, Richards created the subgenus Monocyttarus that coincidentally contained representatives of de Saussure's division Phi (this actually mostly formed by species now placed in the genus Agelaia Lepeletier (1836; see also Bequaert, 1943)). More recently, based on the revised ICZN ( $3^{\text {rd }}$ edition), Carpenter \& Day (1988) reestablished validity (and authorship) of the names created by de Saussure. They also pointed out that because Bequaert (1943) had fixed the type species of Phi as Vespa phthisica Fabricius (1793), incidentally an element of Monocyttarus, this name then turned out to be a junior subjective synonym of Phi. Finally, Cooper (1997a) created the subgenus Scytokeraia for a group of species (with some new additions) that had been placed by Richards (1978) in the subgenera Monogynoecus Richards (1941) and Monocyttarus.

While Richards $(1941,1945)$ by the time of his earlier works had already established the foundations of the present-day subgeneric classification, Zikán (1949) largely ignored his concepts. According to Richards (1978) and with the modifications introduced by Cooper (1997a), the subgenera of Mischocyttarus are the following:

1) Mischocyttarus s. str. de Saussure, 1853. A small group with 12 species, distributed mostly in South America, although the type species M. labiatus (Fabricius, 1804) reaches Panama, and M. melanarius (Cameron, 1906) occurs only in Central America (Richards, 1945, 1978; Zikán, 1949). Mischocyttarus acunai Alayo (1972), from Cuba, was treated by Richards (1978) as a member of Monocyttarus (= Phi Saussure). However, as explained by Silveira (2002), this species is a member of Mischocyttarus s. str., being its endemic and sole element in the Caribbean. Another recent addition to the group is $M$. aripuanaensis described by Silveira (1998) from the Brazilian state of Mato Grosso. Jeanne (1970, 1972) and Litte (1981) respectively published studies about the sociobiology of $M$. drewseni de Saussure (1857) and M. labiatus (Fabricius, 1804).
2) Clypeopolybia Brèthes, 1923. With M. flavicans (Fabricius, 1804) as its type species, this group was referred by Richards (1978) as containing 11 species. However, as shown by Silveira (1998), Mischocyttarus heliconius Richards (1945), M. sericeus Richards (1978), and M. piger Richards (1945) are not proper elements of Clypeopolybia (see below). In his first revision of the genus, Richards (1945) treated the species allied to $M$. flavicans as part of the nominotypical subgenus together with M. labiatus and allies. Later, in his 1978 book, the author removed the $M$. flavicans group to a separate subgenus for which he used the name Clypeopolybia Brèthes, 1923. However, Richards (1978) added to the new subgenus the species of the $M$. heliconius group, which in 1945 he treated as parts of subgenus Kappa (see below). Most species of Clypeopolybia occur in South America, and detailed studies of the behavior are lacking.

3) Haplometrobius Richards, 1978. Erection of this subgenus apparently resulted from Richards decision to confer separate status to the group of $M$. collaris of his previous works (1941, 1945), thus limiting the concept of Megacanthopus to its type species and closely related forms. Erection of Haplometrobius logically followed for the remaining groups of M. prominulus Richards (1941), M. surinamensis (de Saussure, 1854), M. cerberus Ducke (1918), M. artifex (Ducke, 1914) and M. iheringi Zikán (1935). The resulting subgenus is hard to diagnose, and is a very large group with 74 species currently recognized, and with $M$. iheringi as its type species. A considerable amount of work has been recently dedicated to this group. Raw (1985) added a new species to the group of $M$. artifex. Cooper (1996b) recognized a new species-group, M. mendax Richards (1978), adding six new species. Cooper (1998a) described two species in the group of M. iheringi, and in a subsequent paper (1998b), he described five new species in the group of M. artifex. Silveira (2004) described the male of $M$. nomuare Richards (1978) and rearranged the group of $M$. cerberus. Most species of Haplometrobius occur in South America, but various are found from Panama up to Mexico. The colony cycle and social organization of M. cerberus in Brazil has been investigated by Giannotti (1998, 1999).

4) Kappa de Saussure, 1854. With 36 described species (Silveira, 2006), this group was created by de Saussure (1854) as an informal division of the nominotypical subgenus of Polybia. Bequaert (1933) designated P. injucunda de Saussure (1854) as the type species of Kappa solely with the intention of synonymyzing it under Mischocyttarus. However, Richards $(1941,1945)$ used the name at the subgeneric level, but with far wider limits than in his 1978 work. Besides the usual member species, the earlier Kappa concept also included all speciesgroups now in Phi plus M. heliconius Richards. Geographic distribution is Neotropical from Mexico to north of Argentina, most species occurring in the northwest of South America. The group was recently revised by Silveira (2006), and information on the biology and behavior of species can be found in Bequaert (1937), Gorton (1978), London \& Jeanne 
(1996), O’Donnell (1992), Queller et al. (1992), Rapôso-Filho et al. (1994), Silva (1988), Silva \& Oliveira (1989), Silva \& Rodrigues (1987), Starr (1988), and Windsor (1972).

5) Megacanthopus Ducke, 1904. This name was created for a new genus of social wasps containing all species with asymmetrical tarsal segments, which previous authors had assigned to Polybia. While convincingly justifying separation of the new taxon from Polybia, Ducke (1904) only very unsatisfactorily distinguished Megacanthopus from Mischocyttarus. In his key (p. 320), differences between the two taxa refer essentially to body-length related characters. Later, Ducke (1913) recognized the two names as synonyms, and Bequaert (1933) subsequently designated Mischocyttarus collaris (Ducke, 1904) as type species of Megacanthopus. Richards $(1941,1945)$ used the name for a subgenus of Mischocyttarus, with a concept wide enough to include not only the species more similar to M. collaris but all those for which he would subsequently create the subgenus Haplometrobius (see Richards, 1978). Thus, it was only in Richards's last revision that the name Megacanthopus gained its current meaning, corresponding to a small group of ten species possessing unique morphological features. Cooper (1997b) revised the subgenus, adding three new species, and presented notes on the biology and distribution of the species. They occur mostly in South America, only M. collarellus Richards (1940) being recorded from Panama and Costa Rica (Cooper, 1997b; Garcete-Barrett, 1999; O’Donnell, 1999; Richards, 1978).

6) Monogynoecus Richards, 1941. This name was created for a small group of three species having M. lecointei (Ducke, 1904) as type species. Zikán (1949) described three more species, all showing good correspondence to the original concept. However, Richards (1978) included in Monogynoecus some species (described by himself and earlier by Zikán, 1949) that either shared only superficial similarity with typical species of the group in features like the "round" humeral region of pronotum, or primitive widely distributed characters as the presence of a pronotal fovea. The heterogeneous composition of the subgenus was corrected by Cooper (1996a), who removed the outlying species, and subsequently describing a new subgenus for them: Scytokeraia Cooper, 1997a. According to Cooper (1996a), all eight species of Monogynoecus occur in South America east of the Andes. That author also presented information on the natural history of some species.

7) Omega de Saussure, 1854 (= Monacanthocnemis Ducke, $1905)$. Both of these names were created for monotypic groups containing only the species M. filiformis (de Saussure, 1854). Synonymy of Monacanthocnemis under Mischocyttarus was recognized by Ducke (1913). Richards (1941) initially used de Saussure's name to refer to a subgenus composed of $M$. filiformis and allied species, but substituted Ducke's Monacanthocnemis in 1978 following the restrictions then imposed by the International Code of Zoological Nomenclature on infrasubgeneric names. The group comprises seven described species (plus several undescribed ones), most of which occurring in South America. Only M. chalucas Snelling (1983) and one undescribed species from Panama (UCDC, Bohart Museum) occur in Central America. Detailed work on the behavior of the species is lacking.

8) Phi de Saussure, 1854 (= Monocyttarus Richards, 1978). As explained in Carpenter \& Day (1988), synonymy of Monocyttarus under Phi Saussure is consequence of the choice by Bequaert (1943) of Mischocyttarus phthisicus (Fabricius, 1793) as the type species of Phi. Differently from de Saussure's division, however, Richards's taxon is a reasonably homogeneous group, rather easily diagnosable from other subgenera. It is thus ironic that Bequaert chose a Monocyttarus species (instead of an Agelaia one) as type of Phi, and only to make this a synonym of Mischocyttarus. With 75 described species, $P h i$ is one of the largest groups in Mischocyttarus and that with the most extensive geographic distribution. Being mostly Neotropical, four species occur north of Mexico (USA and Canada), four in the Caribbean, and $M$. flavitarsis (de Saussure, 1854) has been introduced in Hawaii. Information on the biology and behavior of the species has been published by Giannotti \& Fieri (1991), Giannotti \& Silva (1993), Litte (1977, 1979), Machado \& Wiendl (1976), RapôsoFilho (1987, 1989), Rapôso-Filho \& Rodrigues (1984 a, and b, 1986, 1987, 1988), Silva \& Rodrigues (1987), and Strassmann et al. (1995).

9) Scytokeraia Cooper, 1997. As mentioned above, creation of this subgenus was linked to corrections made by Cooper (1996a, 1997a) in Monogynoecus. Even Richards (1978) had noted that his species $M$. mastigophorus did not possess the very distinctive male genitalia, typical of the species of Monogynoecus. On the other hand, the threadlike shape of the male antenna in $M$. mastigophorus was unique in the genus, only approached by a few Phi species like M. flavitarsis (de Saussure, 1854) or M. pallidipectus (Smith, 1857). After collecting additional material, including the previously unknown males of other species, Cooper (1997a) perceived the correlation between the distinctive male features and the emarginated female clypeus. He noted that, together with a very low and straight pronotal carina such a combination of characters could not be referred to any of the known groups of Mischocyttarus, thus justifying creation of Scytokeraia with $M$. mastigophorus as type species. The new subgenus also included the species $M$. subornatus Zikán (1949) and $M$. stenoecus Richards (1978), placed by Richards (1978) respectively in the subgenera Monocyttarus (= Phi) and Haplometrobius. Scytokeraia comprises 12 species distributed in Central America and northwestern regions of Andean South America, including the Pacific coast of Colombia (Carpenter \& Wenzel, 1988; Cooper, 1997a; Richards, 1978). Detailed studies on the biology and behavior of M. mastigophorus have been published by O'Donnell (1998, 1999). 
Mischocyttarus has been of great importance for the study of sociobiology in wasps (Jeanne, 1970, 1972; Litte, 1981; O’Donnell, 1999; Queller et al, 1992; Strassmann et al, 1995). The open nests facilitate considerably the observation of behavior. However, further success of these studies depends strongly on a parallel effort to reconstruct phylogenetic relationships within the genus. For other vespid taxa, the recent development of phylogenetic hypotheses (Carpenter, 1982, 1987, 1988a, 1991) has made possible the critical evaluation of competing hypotheses on the evolution of several social features (Carpenter, 1991, 1997; Carpenter et al, 1993; Wenzel \& Carpenter, 1994). The present work is the first cladistic study specifically designed to investigate the phylogenetic relationships within Mischocyttarus. In a recent analysis including various polistine genera, Arévalo et al. (2004) obtained results with some resolution of internal relations within Mischocyttarus, but the few species used represent only three of the nine subgenera currently recognized. In fact, the main objective of that study was to investigate relations within the genus Polistes Latreille, 1802. Here, I use morphological characters of several species of Mischocyttarus from all the subgenera and major species-groups in order to investigate their monophyly and relationships.

\section{MATERIAL AND METHODS}

Terminology. The terminology used to describe characters is essentially that of Richards (1978) with some introduced terms, such as the name "tyloid" to designate special areas on the ventral surface of the male antennal flagellomeres (see Bin et al, 1999; Carpenter, 1991). Major divisions of the body are named as in Goulet \& Huber (1993).

Selection of Taxa.Complete reference to author and year of publication of taxon names cited in this study are presented in Table 1 and Appendix 1. The analysis was based on 71 terminals (Tables I, II, and Appendix 1) representative of the morphological diversity observed in 181 named species and subspecies of Mischocyttarus (plus several undescribed) from all currently recognized subgenera (see Appendix 1). Addition of exemplar species as terminals was preferred as a method of representing the variation within a group. However, for five species-groups within Mischocyttarus, ground-plan assumptions or polymorphic terminals were used. Table I shows the list of terminals with the respective species-groups or taxa represented, and other relevant information on taxa or specimens and their depositories.

The three remaining tribes of Polistinae (see Carpenter, 1993) were chosen to compose the outgroup: Polistini (consisting of Polistes Latreille, 1802), Ropalidiini (comprising Ropalidia Guérin-Menéville, 1831; Parapolybia de Saussure, 1854; Polybioides Buysson, 1913; and Belonogaster de Saussure, 1854), and Epiponini (formed by nineteen Neotropical swarming genera) (Appendix 1). Characters of all four genera of Ropalidiini were used to infer states of the composite terminal representing the group. For the Epiponini, ground-plan characters were inferred based on the conditions observed in Apoica Lepeletier and Agelaia Lepeletier, two basal lineages in the tribe (Carpenter, 1991).

Providers of specimens for the study. Examined material representative of the taxa cited in Table 1, and Appendix 1 was loaned from various institutions worldwide. For Mischocyttarus species, holotypes and/or paratypes were examined in most cases (75\%), and complete collecting data and depository for them are available in the works of Richards (1940, 1945, 1978), Silveira (1998, 2006), and Zikán (1935, 1949). In the present work, collecting information is only presented for critical taxa, i.e. undescribed or unidentified forms, and taxonomically problematic species (see Table 1). Contributing collections (abbreviations as in Arnett et al, 1993) and their respective curators are as follows: American Entomological Institute, Gainesville (AEIC; Dr. David Wahl); American Museum of Natural History, New York (AMNH; Dr. James Carpenter); Natural History Museum, London (NHM; Ms. Christine Taylor); California Academy of Sciences, San Francisco (CASC; Dr. W. Pulawski and Dr. D. Ubick); Carnegie Museum of Natural History, Pittsburgh (CMNH; Dr. John Rawlins); Estación de Biologia Chamela, San Patricio, México (EBCC; Dra. Alicia Rodríguez-Palafox $\dagger$; Dr. Ricardo AyalaBarajas); Essig Museum, Berkeley (EMEC; Dr. Cheryl B. Barr); Florida State Collection of Arthropods, Gainesville (FSCA; Dr. J. Wiley); Museo Fairchild, Universidad de Panama (GBFM; Dr. Roberto Cambra T.); Instituto de Pesquisas Científicas e Tecnológicas do Estado do Amapá, Macapá (IEPA; Mr. José Madson Gama); Instituto Miguel Lillo, Tucumán (IMLA; Dr. Abraham Willink †; Dra. M.aria Virginia Colomo de Correa); Instituo Nacional de Biodiversidad, Santo Domingo (INBC; Dr. Jesus Ugalde and Dr. Jorge Carvajal Alfaro); Instituto de Zoologia-Academia de Ciências de Cuba (Dr. Luis F. de Armas); Museo Nacional de Historia Natural del Paraguay, Asunción (INBP; Dr. John Kochalka and Dr. Bolivar Garcete-Barret); Instituto Nacional de Pesquisas da Amazônia, Manaus (INPA; Dra. Catarina Motta and Dr. Augusto Henriques); Fundação Instituto Oswaldo Cruz, Rio de Janeiro (IOC; Dr. Sebastião José de Oliveira †; Dra. Jane Margaret Costa von Sydow); Museum of Comparative Zoology, Cambridge (MCZC; Dr. Philip Perkins); Museum National d'Histoire Naturelle, Paris (MNHN; Dr. Janine Casevitz-Weulersse and Dr. Claire Villemant); Museu Nacional do Rio de Janeiro, Quinta da Boa Vista (MNRJ; Dr. Miguel A. Monné and Dra. Rita Tibana); Museu Paraense Emílio Goeldi, Belém (MPEG; Dr. Terezinha Pimentel and Dra. Ana Harada); Museu de Zoologia da Universidade de São Paulo, São Paulo (MZSP; Dr. Carlos R. F. Brandão); Museum Für Naturkunde Humboldt-Universität, Berlin (ZMB; Dr. Koch Wessel); National Zoological Collection of Suriname (NZCS; Dr. H. Hiwat-van-Laar); Naturhistoriska Riksmuseet, Stockholm (NHRS; Dr. Lars-Ake Janzon); Rice University, Texas (Dr. Joan Strassmann); Bohart Museum, University of California at Davis, Davis (UCDC; Dr. S. L. Heydon); Universidade Federal do Maranhão, S. Luís (UFMA; Dra. Gisele Garcia); Universidade Federal do Paraná, Curitiba 
(UFPR; Dr. Gabriel A. R. de Melo); University of Ibaraki, Mito (Dr. Dr. Jun-ichi Kojima); Smithsonian Institution, Washington (USNM; Dr. Ronald J. McGinley and Dr. David G. Furth); Zoologische Saamlung des Bayerischen Staates, Munich (ZSMC; Dr. Johannes Schuberth); Dr. Carlos E. Sarmiento, Colômbia.

Preparation of Specimens. Most characters were studied under a stereomicroscope, and drawings were made with a camera lucida. For preparations of the male genitalia, the terminal part of the metasoma was softened with $10 \% \mathrm{KOH}$ and removed with forceps, and then heated in $\mathrm{KOH}$ for 10 minutes. After cleaning in distilled water and dehydration, the pieces of the terminalia were preserved in plastic microvials containing a 1:1 mixture of $70 \%$ alcohol and glycerin. Observation of the genitalia was made under the microscope in a Petri dish filled with alcohol, and with the help of a small positioning support made with an extra-fine electric copper wire conveniently twisted (suggested by S. T. P. Amarante).

Ventral surface of the male flagellomeres and other parts were studied with scanning electron microscopy (SEM). Part of the images were obtained in the "Departamento de Microscopia Eletrônica da Universidade de São Paulo", with ZEISS equipment, and captured as computer files or KODAK 5-PXP 120 film. Most of the SEM's were made in the "Departamento de Fitopatologia da EMBRAPA", in Belém, with JEOL equipment and image reproduction by POLAROID 667 film. Dirty specimens were bathed for $24 \mathrm{~h}$ in commercial synthetic detergent (VEJA), washed in slow current water, cleaned with a soft brush, and then put to dry in a stove at $50^{\circ} \mathrm{c}$. Critical point drying was not considered necessary, and in some cases a chloroform bath was used prior to air-drying.

Larval characters were observed in alcohol preserved specimens or, in a few instances, in dry mummified specimens removed from nests in collections. In spite of the larval collections gently provided by Dr. Garcete-Barrett (Paraguayan specimens) and Dr. J. Kojima (Ropalidiini specimens), scoring the states for a number of terminals depended on information from the literature (Cooper, 1996a, 1996b, 1997a, 1997b; DiasFilho, 1975; Kojima, 1998; Reid, 1942; Richards, 1945, 1978).

Information on Mischocyttarus species not directly examined was obtained from the literature, especially Richards (1941, 1945, 1978), Zikán (1949), Raw (1985, 1996) and Cooper (1996a, 1996b, 1997a, 1997b, 1998a, 1998b). In one case, occurrence of an expected condition (male antenna lacking hairs) was inferred in M. chanchamayoensis, in spite of being not explicitly mentioned by Cooper (1998a). It is judged that occurrence of the alternative state would certainly be noted by the author. Information about the genera composing the outgroup was found in the works of Richards $(1973,1978)$, Kojima (1982, 1984, 1998), Kojima and Kojima (1988), and Carpenter (1991, 1996).

Character Coding. Characters used in this study were constructed in three ways: (1) simple alternative conditions (e. g., presence/absence of pronotal fovea); (2) more complex shapes constituted by two or more correlated elements of form (composite coding of Wilkinson, 1995); (3) by recognizing a very different extreme condition among a set of otherwise poorly differentiated forms considered to be one same alternative state (e.g., the deep lateral indentations of the female clypeus as a putative synapomorphy of Clypeopolybia). Multistate characters are ordered in cases where a linear series of related shapes was evident. Missing information (mostly about males and larvae) is represented in the matrix (Table II) by a question mark (?). Ambiguity is scored as a minus sign (-).

Polymorphic Terminals. None of the subgenera of Mischocyttarus could be represented in the study by a single terminal. In general, the recommendation of Nixon \& Davis (1991) was followed, i.e. to increase the number of representative terminals (species). In some cases, however, polymorphic terminals had to be used when treating the occurrence of a character with more than one state within a single species (e.g., M. immarginatus) or in a composite terminal representing a group of species (e.g., Ropalidiini, or the $M$. punctatus group).

Phylogenetic Analysis. The data matrix was analyzed by both unweighted standard parsimony and parsimony analysis under implied weights (Goloboff, 1993a). WinClada 1.00.08 (Nixon, 2002) was used for editing the matrix and inspection of trees generated by NONA 2.0 and Pee-Wee 3.0 (Goloboff, 1993 b). Character support for groups was evaluated in WinClada using option "unumbiguous changes only" (as to methods of optimization of character changes). Matrix was run in NONA and Pee-Wee with options amb-, mult*50. Command "jump*" was used to jump between islands of trees separated by specified differences in fit or number of steps. The program TNT 1.0 (Goloboff et al, 2005) was also used for exploring the data. Any presented consensus tree is the strict consensus. Absolute and relative Bremer supports (Bremer, 1994; Goloboff \& Farris, 2001) were estimated in NONA and Pee-Wee using the following command sequence (as suggested by P. Goloboff to J. Carpenter; in lit.):

"first find shortest trees, and then..." $>$ out filename; <enter $>$

$>$ hold 1000 ; sub 1 ; find $*$; <enter>

$>$ hold 2000 ; sub 3 ; find *; <enter $>$

$>$ hold 4000 ; sub 5 ; find * ; <enter >

(in this work expanded until collapsing of basalmost branches of the ingroup)

$>$ hold 6000; sub 7; find $*$; <enter>

$>$ hold 8000; sub 9; find ${ }^{*}$; <enter >

$>$ bsupport ; bsupport*; <enter $>$

$>$ quit <enter>

(and for implied weights)

$>$ hold 1000; sub 10; find $*$; <enter>

$>$ hold 2000; sub 30; find $*$; <enter $>$

$>$ hold 4000; sub 50; find ${ }^{*} ;<$ enter $>$

$>$ bsupport ; bsupport*; <enter $>$

$>$ quit <enter $>$ 
Implied weights analysis performed with Pee-Wee with the constant of concavity " $\mathrm{k}$ " set to 1 is considered main reference regarding the phylogenetic knowledge attained in the study (character changes presented on Appendix 2 refer to trees found under this concavity value). However, other values of " $\mathrm{k}$ " are also evaluated, and with the purpose of making classificatory changes, results of weighted analyses with " $\mathrm{k}$ " varying from 1 to 3 are taken as reference. Bremer support values for Pee-Wee trees are presented for these analyses only.

\section{RESULTS}

Character analysis (complete data matrix presented in Table II)

\section{HEAD}

1. Occipital region: (0) with salient carina dorsally and laterally; (1) just compressed dorsally and laterally; (2) compressed only dorsally; (3) occiput unmargined. (Ordered 0-1-2-3).

State 0 occurs in all the genera used as outgroups. In Mischocyttarus, however, a carinate occiput occurs only in groups probably distantly positioned from the base of the phylogeny, as in some species of the heliconius and iheringi groups, in the prominulus group, in the subgenus Omega (Monacanthocnemis of Richards, 1978), and in most species of Kappa. Cooper (1996a) recently described M. onorei, a species in the subgenus Monogynoecus presenting a carinate occiput. This is a remarkable finding since all other species in that subgenus lack an occipital carina. The description of $M$. onore $i$ is incomplete in respect of many of the characters used in this work, so that it could not be included as an independent terminal in the analysis. According to Cooper, $M$. onorei has a pointed clypeus, the pronotal carina is acute at sides, and the pronotal fovea is absent. No other species in Monogynoecus presents a similar combination of characters. Mischocyttarus insolitus has a pointed clypeus and the pronotal fovea is absent, but the pronotal carina is almost completely reduced at sides, similar to the condition in M. lecointei. Inclusion of the states occurring in $M$. onorei as polymorphisms in one of the three species-groups used as terminals in Monogynoecus would be too much tentative since that species does not fit easily in any of these groups.

2. Dorsal part of the head behind eyes and ocelli (degree of lengthening backwards, elevation, and profile in dorsal view): (0) surface behind ocelli curved and strongly dipping backwards, occipital margin (or the corresponding region) very low, distinctly positioned below the plane of the vertex, dorsal profile variably concave (Fig. 6); (1) surface behind ocelli reasonably planar and lengthened backwards, region corresponding to occipital margin quite elevated and practically in the same plane of the vertex, dorsal profile only a little concave (Fig. 5); (2) all the posterior dorsal part (and gena) of the head very narrow, surface behind eyes and ocelli very short and with a strong dip backwards, dorsal profile gently concave (Fig. 7). (Unordered)

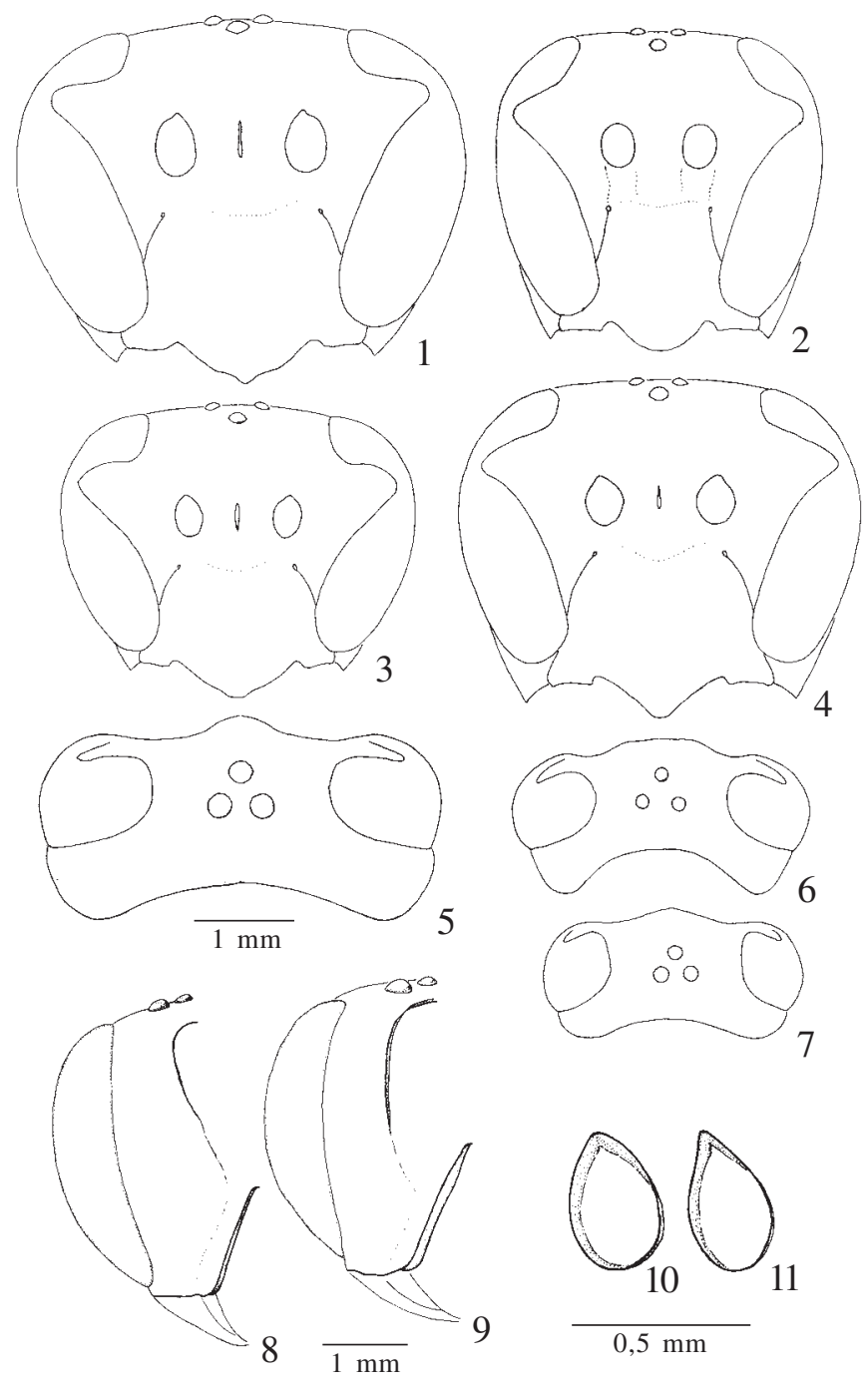

Figs. 1-11. Frontal view of female head in 1, M. laurae; 2, M. acunai; 3, M. metathoracicus; 4, M. flavitarsis; dorsal view of female head in 5, M. aripuanaensis; 6, M. cerberus; 7, M. stenoecus; lateral-posterior view of female head showing hypostomal lamella in 8, M. ornatus; 9, M. chanchamayoensis; female left antennal socket in 10, M. malaris; 11, M. buyssoni.

State 1 occurs typically in M. (Mischocyttarus) aripuanaensis, and in M. flavicans and M. carbonarius of Clypeopolybia. Similar shapes were observed in some species of Polistes and Ropalidia, which nonetheless have an evident occipital carina. State 2 is a putative synapomorphy of Scytokeraia.

3. Posterior part of the head around occipital foramen: (0) produced into a shallow cavity with a smoothly rounded boundary; (1) produced into a deep cavity below, its ventral portion nearly horizontal but not sharply margined; (2) produced into a deep cavity below, its ventral portion horizontal, sharply margined, like a shelf (Fig. 135). (Ordered 0-1-2)

State 2 typically occurs in Omega and most species of 
Table I. Ingroup and Outgroup (OG) terminals used in phylogenetic analyses.

1) Polistes Latreille, 1802. (OG)

2) Ropalidiini sensu Carpenter (1993). (OG)

3) Epiponini sensu Carpenter (1993). (OG)

Subgenus Kappa de Saussure, 1854.

4) Michocyttarus immarginatus Richards, 1940.

5) Michocyttarus laurae Silveira, 2006. A species described by Silveira (2006) based on the female holotype only (Venezuela, Merida, Guarunes, no date, P. Anduze; AMNH).

6) M. tolensis Richards, 1941 .

7) M. latior (Fox, 1898).

8) M. metathoracicus (de Saussure, 1854).

9) M. funerulus Zikán, 1949.

Subgenus Haplometrobius Richards, 1978.

10) M. cerberus Ducke, 1918; representing M. nomurae Richards, 1978 and M. peruanus Zikán, 1949.

11) M. dimorphus Zikán, 1949 and M. narinensis Cooper, 1998. Two quite similar species, characters of male genitalia observed in M. narinensis (Colombia, Valle, Buenaventura, Rio Calima, 40m, 8/ix/1995, C. Sarmiento coll.); referred to in matrix as "dimorphus-narinensis".

12) group of M. mendax Richards, 1978, sensu Cooper (1996b). Material examined: female, holotype of M. mendax; female and male, Peru (no date), Ducke collection (MPEG), corresponding respectively to descriptions of $M$. montivagus and $M$. reclusus Cooper (1996b); female, Brasil, Pará, Caxiuanã, 18/x/1998 (Silveira \& Pena) (MPEG), corresponding to description of $M$. tectus Cooper (1996b).

13) group of M. heliconius iperuae Richards, 1978. A small group of very similar forms, part of them mistakenly referred by Richards (1945, 1978) to his concept of M. undulatus (Ducke, 1904) (see Carpenter, 1999). Material examined: female, Colombia, Putumayo, Mocoa, 25/viii/1978, female, Bolivia, Beni, Rurrenabaque, 270m, 26/iv/1979 (M. Cooper) (NHM); female, Brasil, Pará, S. Norte, Manganês, 1-3/vii/1985 (M. Zanuto), male, Brasil, Acre, P. N. Serra do Divisor, 9/iii/1997 (E.F. Morato) (MPEG); referred to in matrix as "iperuae group".

14) M. heliconius Richards, 1945.

15) M. chanchamayoensis Richards, 1978. The male was not examined but some characters were obtained in Cooper (1998a).

16) M. artifex (Ducke, 1914).

17) M. interjectus Zikán, 1935; representing M. capichaba Zikán, 1949.

18) M. sylvestris Richards, 1945; representing M. lemoulti (Buysson, 1908).

19) Mischocyttarus (Haplometrobius) sp1. Unidentified species similar to M. peruviensis Richards, 1945. Material examined: female, Brasil, Amapá, Amapari, Tucano 2, 9-11/xi/1993 (F. F. Ramos) (MPEG); male, Brasil, Amazonas, Estirão do Equador, R. Javarí, ix/1979 (Alvarenga) (MZSP); referred to in matrix as "gr artifex sp".

20) M. oecothryx Richards, 1940; representing M. synoecus Richards, 1940, M. nigroclavatus Zikán, 1949, M. reflexicollis Zikán, 1949, M. undulatus (Ducke, 1904) and M. interruptus Richards, 1978.

21) M. mirificus Zikán, 1935; representing M. ypiranguensis Fonseca, 1926, M. schadei Zikán, 1949, and M. thrypticus Richards, 1945.

22) M. cooperi Richards, 1978; possibly representing M. naumanni Richards, 1978, and M. vredeni Richards, 1978.
Table I. Cont.

23) M. ornatus Zikán, 1949; representing M. longicornis Zikán, 1949.

24) M. weyrauchi Zikán, 1949.

25) M. iheringi Zikán, 1935; representing M. travassosi Zikán, 1949, M. curytibanus Zikán, 1949, and M. saussurei Zikán, 1949.

26) Mischocyttarus (Haplometrobius) sp.2 (= M. undulatus sensu Richards, 1978; in part). Material examined: Brasil, Mato Grosso, 1 female, 2males, 10/ix/1968, 2 females, 12/ix/1968 (O. W. Richards) (NHM). This is a distinct unnamed species, one of the forms that have been confounded by Richards (1978) under the name "undulatus"; referred to in matrix as "gr iheringi sp"

27) M. nigropygialis Zikán, 1949; possibly representing $M$. macarenae Cooper, 1998.

28) group of M. elegantulus Zikán, 1949. This terminal combines characters of the female of $M$. elegantulus and those of a male specimen from Colombia, Meta, Villavicencio, 530m, 30/iv/1995 (C. E. Sarmiento, private collection), possibly the same species; representing M. prominulus Richards, 1941.

29) M. silvicola Zikán, 1949.

30) group of M. alboniger Richards, 1978. Small group of unidentified species with morphology and color similar to M. alboniger. Material examined: Brasil, female, Amazonas, Rod. AM-010 Km 31 Embrapa, 30/x/1991 (L. F. Albuquerque \& J. Hinda), female, Roraima, R. Uraricoera, I. de Maracá, 21-30/xi/1987 (J. A. Rafael e equipe) (INPA); Pará, Bujarú, female, 30/vi/1977 (P. Waldir \& L. Braack), female and male, 14/viii/1977, female, 15/viii/1977 (P. Waldir), female, 16/iv/1982 (W. França), Moju, 3 females, 10/viii/1977 (P. Waldir), Belém, Utinga, female and male, 16/x/1996 (O. T. Silveira) (MPEG).

31) M. confusus Zikán, 1935; representing part of the species of the group of M. surinamensis (de Saussure, 1854) possessing the first metasomal segment short, as in M. ignotus Zikán, 1949, $M$. hoffmanni Zikán, 1949, and M. garbei Zikán, 1935.

32) Mischocyttarus (Haplometrobius) sp. 3. Unidentified species, with examined specimens from Panama and other countries of Central America. The male has the antennal apex very short, an atypical condition in the group of $M$. surinamensis. Material examined: Costa Rica, female, Go. Ifito, 14/vii/1957 (Truxal \& Menke) (UCDC); México, female, Quintana Roo, nr. Coba Ruins, 20/xii/1982 (S. Meredith) (EMEC); Panamá, 2 females, Rancho Frio, Cerro Pirre Darien, 7/iv/1986 (D. Windsor) (GBFM), Barro Colorado, female, 12/ii/1955 (C. Rettenmeyer), female, 23/vii/ 1963 (Cavagnaro \& Irwin), male 10/viii/1981 (R.B. \& L. S. Kimsey) (UCDC); referred to in matrix as "gr surinamensis sp".

33) group of $M$. surinamensis (de Saussure, 1854): This terminal represents the forms more strictly similar to M. surinamensis, with a more elongated first metasomal segment, as in $M$. bahiaensis Zikán, 1949, M. decimus Richards, 1978, and M. tricolor Richards, 1945.

Subgenus Phi de Saussure, 1854 (sensu Richards, 1978)

34) M. itatiayaensis Zikán, 1935; representing species of the group of M. alfkenii (Ducke, 1904) in which the male has the clypeus narrowly separated from the eyes, and the antennomere 13 is two times longer than wide, as in M. costalimai Zikán, 1949, M. araujoi Zikán, 1949, M. scitulus Zikán, 1949, M. infrastrigatus Zikán, 1949, and M. riograndensis Richards, 1978.

35) M. alfkenii (Ducke, 1904); representing M. flavicornis Zikán, 1935.

36) M. basimacula (Cameron, 1906). 
Table I. Cont.

37) M. mexicanus (de Saussure, 1854). This and the next two species represent a set of species of the group of $M$. flavitarsis in which the male has a very short antenna, with the apex normal, not "hook-like", the antennomere 13 being typically very short and wide, as in M. phthisicus (Fabricius, 1793), M. costaricensis Richards, 1945, and "M. angulatus morph ictericus" Richards (1945).

38) M. angulatus Richards, 1945.

39) M. mexicanus cubicola Richards, 1978.

40) M. extinctus Zikán, 1935 . This species is similar to M. crypticus Zikán, (1949) both with the clypeal ventral angle very acute and the apex perfectly rounded. However, M. crypticus has the pronotal carina with a distinct lamella and the tyloids of the male antenna are reduced as in remaining species of Phi. In $M$. extinctus, the tyloids are larger and well defined as in the other subgenera.

41) M. consimilis Zikán, 1949.

42) M. cassununga (von Ihering, 1903).

43) M. pallidipectus (Smith, 1857). This and the next four species share marked similarities regarding the very wide male gena, and very strong and robust male mandible.

44) M. flavitarsis (Saussure, 1854).

45) M. marginatus (Fox, 1898).

46) M. hirtulus Zikán, 1949.

47) Mischocyttarus (Phi) sp. Undescribed species very similar to $M$. hirtulus. Material examined: female and male, Colombia, Antioquia, Heliconia, Humareda 1, 15/i/1997 (Y. Vargas) (MPEG); referred to in matrix as "nr hirtulus sp".

48) M. tarmensis Richards, 1945 (= M. huacapistanus Zikán).

49) group of $M$. hirsutus Richards, 1945. This terminal represents several examined forms from Colombia similar to M. hirsutus Richards, for which no types or identified specimens were available. Material examined: female and male, Nariño, Barbacoas, 1.200m, 22/vii/1995, 2females, Valle, Anchicayá, Hiodroelectrica bajo Anchicayá, El engaño, 260m, 24/iii/1995, female, Caldas, Aguadas La Herencia, 2.170m, 23/i/1996, female, Parque Nacional Tatamá, Risaralda, R. San rafael, 4/1/1993 (C. E. Sarmiento, private collection).

50) M. wagneri (Buysson, 1908).

51) M. alternatus Zikán, 1949; representing M. confirmatus Zikán, 1949.

52) M. campestris Raw, 1985. Information about characters of the male were obtained in Raw (1985); representing M. chapadae (fox, 1898).

Subgenus Clypeopolybia Brèthes, 1923 (sensu Silveira, 1998)

53) M. richardsi Zikán, 1949; representing the smaller species of Clypeopolybia, like M. wygodzinkyi Zikán, 1949, M. clypeatus Zikán, 1935, and M. adjectus Zikán, 1935.

54) M. duckei (Buysson, 1908).

55) M. flavicans (Fabricius, 1804).

56) M. carbonarius (Saussure, 1854).

57) M. carbonarius tibialis Richards, 1978. This form is in fact distinct from the nominotypical taxon. Material examined: Brasil, Amazonas, male, Serra de Parintins, 15/ix/1907 (A. Ducke) (MPEG); Costa Rica, Heredia, 2 females, Est. El Ceibo, PN Braulio Carrillo, 400-600m, ii/1990 (C. Chaves \& R. Aguilar) (INBC).

Subgenus Mischocyttarus de Saussure, 1853 (sensu Silveira, 2002) 58) M. acunai Alayo, 1972.
Table I. Cont.

59) M. aripuanaensis Silveira, 1998; male, larva, and nest are unknown.

60) M. smithii de Saussure, 1853.

61) M. drewseni de Saussure, 1857.

62) M. tomentosus Zikán, 1935; representing those species with the first metasomal segment very elongate, as in M. labiatus (Fabricius, 1804), M. melanarius (Cameron, 1906) and $M$. rotundicollis (Cameron, 1912).

Subgenus Monogynoecus Richards, 1941 (sensu Cooper, 1996) 63) M. lecointei (Ducke, 1904); representing M. insolitus Zikán, 1949.

64) M. montei Zikán, 1949; representing M. foveatus Richards, 1941.

65) Mischocyttarus (Monogynoecus) sp. Undescribed species from Brazilian Amazonia. Material examined: Brasil, Amazonas, 3 females, Paraná do Xiboreninho, 7/viii/1979 (Adis e equipe) (INPA), Pará, female and male, Belém, Faz. Velha, 20/vii/1977 (P. Waldir) (MPEG); referred in matrix as "Monogynoecus sp".

Subgenus Omega de Saussure, 1854.

66) group of M. punctatus (Ducke, 1904). This terminal combines the female characters found in M. punctatus and M. vaqueroi Zikán (1949) and the male characters of an undescribed form from Bolivia which Richards (unp. manuscript) labeled with a manuscript name. Material examined: Bolivia, 2 females, Beni, Rurrenabaque, 23/iv/1979, female and male, La Paz, Caranavi, 600m, 16/v/1979 (M. Cooper) (NHM); Brasil, Maranhão, female, lectotype of M. punctatus (MPEG), Pará, 2 females, Óbidos, xii/1913, female and male (lacking part of the metasoma) R. Cuminá Mirim, Trombetas, 13/xii/1906 (Ducke) (MPEG), female, Pará (without locality and date) (Baker) (UCDC), Amazonas, female, $60 \mathrm{Km} \mathrm{N}$ Manaus, 22/ii/1979 (Montgomery et al), female, C. Univ., 4/vi/1982 (J. A. Rafael) (INPA); Panama, female, Barro Colorado, 29/vii/1956 (C. W. \& M. E. Rettenmeyer) (UCDC); female, Peru, holotype of M. vaqueroi (IOC).

67) group of M. buyssoni (Ducke, 1906). Includes at least two undescribed forms and M. napoensis Richards (1978). Material examined of the two undescribed species: Brasil, Pará, Serra Norte, 2 females, Serraria, 15/vi/1985 (R. D. Thomaz); 3 females, Fofoca, 16/ix/1985 (M. F. Torres); 2 males, Fofoca, 16/ix/1985 (M. F. Torres) (MPEG).

68) M. filiformis (de Saussure, 1854).

Subgenus Megacanthopus Ducke, 1904

69) M. collarellus Richards, 1940; representing most of species of the subgenus, in which the male has the antennomere 13 strongly enlarged and compressed.

70) group of M. malaris Richards, 1978. This terminal represents a smaller subset of species in which the male has the antennomere 13 normal, not enlarged and compressed, as in M. malaris Richards, M. inexpectatus Cooper (1997) and a third undescribed species from Brasil, Mato Grosso, Buriti, 8/ii/1961 (J. \& B. Bechyné) (MPEG). Characters of the male antenna in the analyzed matrix correspond to a specimen from Pará, Belém, Utinga, 9/iii/1977 (A. Y. Harada) (MPEG) similar in general to M. malaris (Richards, 1978; Cooper, 1997b).

Subgenus Scytokeraia Cooper, 1997.

71) M. stenoecus Richards, 1978.

72) M. subornatus Zikán, 1949.

73) M. mastigophorus Richards, 1978.

74) M. alienus Richards, 1978. 
Kappa. An intermediate condition (state 1) is present in $M$. (Kappa) immarginatus, and in Megacanthopus species.

4. General shape of the head in frontal view: (0) head nearly as wide as high, its contour roughly quadrangular or circular (Figs. 2, 4); (1) head much wider than high, its contour being laterally prominent at the level of ocular sinus, roughly triangular (Figs. 1, 3).

State 1 is observed only in the subgenus Kappa.

5. Hairs on posterior ventral part of the gena: (0) short and rarefied, inconspicuous; (1) longer and more numerous; (2) produced into very long and dense often silvery pilosity. (Ordered 0-1-2)

State 0 occurs in the outgroup and in most species-groups in Mischocyttarus. State 2, the extreme condition occurs in Omega (Monacanthocnemis of Richards, 1978), Kappa, and in part of $P h i$. In the latter subgenus, however, one can see an intermediate condition (state 1 ) in some species like $M$. alfkenii and M. basimacula, and in similar way also in the subgenus Scytokeraia, and in part of Megacanthopus.

6. Frontal region of the head in female: (0) not or not remarkably protuberant; (1) strongly protuberant.

State 1 occurs in the species of the prominulus group, and in the punctatus group (Omega). Maybe this character is correlated with miniaturization of the body. In the punctatus group, frons shape looks more inflated in the smaller individuals, as is the case in specimens of M. vaqueroi.

7. Distal margin of the clypeus in female (presence and shape of a pre-marginal carina related topologically to the distal transversal row of bristles): (0) pre-marginal carina undeveloped, only indicated by a low edge, true margin of clypeus well apparent in frontal view as an acute border (Fig. 136); (1) carina developed but receded medially, margin of clypeus as a thin border; (2) carina developed, margin of clypeus wider looking as a round border (Fig. 137); (3) carina well developed, and projecting downwards beyond true margin of clypeus so delimiting a shallow marginal sulcus (Figs. 138140). (Unordered)

State 0 occurs in outgroups but was not observed in Mischocyttarus. State 1 occurs in three species of the nominotypical subgenus and state 2 occurs in this and in Clypeopolybia. State 3 occurs in the remaining subgenera.

8. Apex of the clypeus in female: (0) narrowly truncate (Fig. 16); (1) pointed lobe (Fig. 14); (2) widely truncate (Fig. 15); (3) bidentate (Figs. 12-13); (4) narrowly rounded (Fig. 17); (5) widely rounded (Fig. 2). (Unordered)

State 1, occurring only in the Ropalidiini and Epiponini is uninformative about relationships within Mischocyttarus. This state could well correspond to the (unobserved) pointed clypeus of $M$. onorei, as described by Cooper (1996a), a species that also has the occiput carinate, a plesiomorphic character in Polistinae.

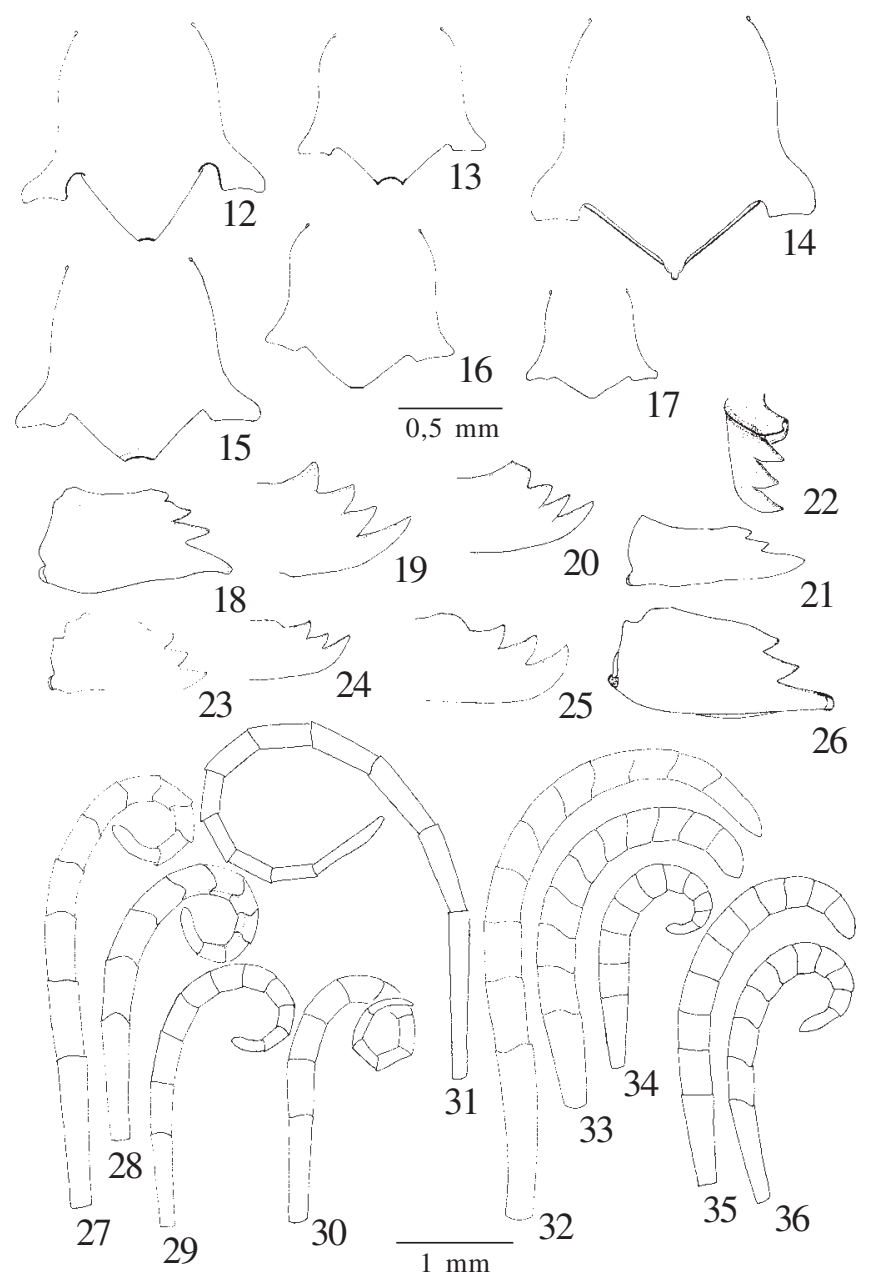

Figs. 12-36. Frontal view of female clypeus in 12, M. duckei; 13, M. mastigophorus; 14, Parapolybia indica; 15, M. drewseni; 16, M. iheringi; 17, M. elegantulus; aspect of male mandible in $18, M$. tarmernsis; 19, M. pallidipectus; 20, M. costalimai; 21, M. dimorphus; 22, 23, M. richardsi; 24, M. labiatus; 25, M. imitator; apical view of female mandible in $26, M$. tolensis; lateral aspect of male antenna in 27, M. stenoecus; 28, M. interjectus; 29, M. surinamensis; 30, M. (Omega) sp. (MPEG); 31, M. subornatus; 32, M. duckei; 33, M. acunai; 34, M. (Omega) sp. (NHM); 35, M. costalimai; 36, M. montei.

9. Lateral symmetric indentations of the female clypeus: (0) indentation shallow or only moderately deep, contour of median lobe of the clypeus continuous with the lateral parts (Figs. 13-17); (1) indentation very deep, median lobe of the clypeus appearing detached from the lateral parts (Fig. 12).

State 1 occurs typically in Clypeopolybia, but some species in other groups present similar conditions as $M$. (Phi) pallidipectus, and $M$. tectus of the mendax group (Haplometrobius sensu Richards, 1978). The latter speciesgroup is treated as polymorphic for this character in the matrix.

10. Margin of hypostoma: (0) margin with a low lamella (Fig. 8); (1) margin with a very high lamella, particularly ventrally near mandible articulation (Fig. 9). 
Table II. Matrix of observed character states in Mischocyttarus and other polistine tribes (1 - 62). Symbols: (?) unknown; (-) ambiguous; (*) polymorphism (see footnote list).

Polistes
Ropalidiini
Epiponini
immarginatus
laurae
tolensis
latior
metathoracicus
funerulus
cerberus
dimorphus-narinensis
mendax group
iperuae group
heliconius

heliconius

chanchamayoensis artifex

interjectus

sylvestris

gr artifex sp

oecothrix

mirificus

cooperi

ornatus

weyrauchi

iheringi

gr iheringi sp

nigropygialis

elegantulus group

silvicola

alboniger group

confusus

gr surinamensis sp

surinamensis group

itatiayaensis

alfkenii

basimacula

mexicanus

angulatus

mexicanus cubicola

extinctus

consimilis

cassununga

pallidipectus

flavitarsis

marginatus

hirtulus

nr hirtulus sp

tarmensis

hirsutus group

wagneri

alternatus

campestris

acunai

richardsi

duckei

flavicans

carbonarius

carbonarius tibialis

aripuanaensis

smithii

drewseni

tomentosus

lecointei

montei

Monogynoecus sp
punctatus group

buyssoni group

filiformis

collarellus group

malaris group

stenoecus

subornatus

mastigophorus

alienus

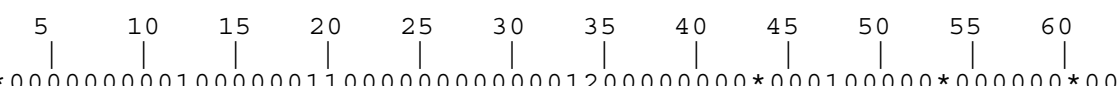
$0 * 0000000001000000110000000000001200000000 * 000100000 * 000000 * 00$
$0 * 000001000 * * 000001 * 0000000 * 000012-0000001000010000 * 1-000 * 0000$ $0000000100001000002100000000000012-000000102001000011-00040--$ $301120340012110121230002103000113330002 * 0100011021101202121000$ 01011034011111101013000210300011333000200 ? ? ? ? ? ? ? ? ? ? ? ? ? ? ? 0021203401121100201300021030011133310122010003102100120212 ?? ?? 30212034001200012013000210300111333101220100011021001202121000 00212034001200002013000210300112333101220100021021101202121000 00212034001200022013000210300112333101220100031021001202121000 30000030001100022011021210100011121000000100021021041002012000 3000003000110002201102121010001212100000010002102104100201 ? 000 $30000033 * 01000000010000210100012121000000100021011021002042-00$ *00000340*110010101000021010001*12100000010002101101120204???? 00000034011100101010000210100012121000000 ?? ??????????????????? 00000034011000101010000210100012121000000 ? 0 ? 0210 ? 1 ? ? ? ? ? ? ? ? 000 1000003300100012101103121010001212100000010013101101124204 ? 300 1000003300100012101100121010001212100000010013102101104204 ? 200 $30000033001000020011001210100012121000000100031021011042042 * 00$ 3000003300100002001100121010001212100000010002102101104204 ???? 20000033001000121011021210100012121000000100131021011042042300 3000003300100002101100121010001212100000010001101101104203 ? 300 10000030001000111011001210100012121000000100121011011322032400 $1000003000100010101100121010001212100000010012101102132203 ? 500$ 10000030001100101012021210100011121000000100121011021322032400 1000003000100012101100121010001212100000010012101102132203 ? 500 00000030001100121011000210100012121000000100121011021322032000 0000003000100012101100121010001212100000010012101102132203 ? 300 000001340010002020110212101000121210000001001110110315010 ? ? 000 00000134001010202011031210100012121000011100111011031501022 ? ? $00000134001000202011021210100 * 12221000001100011011031501022000$ 2000003400101020201102121010001212100000010012101103150102 ? 000 3000003400100000201102121010001212100000010011101101150102 ? 000 30000034001000102011021210100012121000000100121011031501022000 3000103000110002101202021010001123100022011100101000100200 ? 000 30001030001100021012020210100011231000220101001010001002002000 3000103000110002102202021010001123100022010100101000100200 ? 000 30002030001100011022000210100011232000220101001010001002002200 3000203000110000102202021010001123200022010100101000100200 ?? ?? $3000103000110001102200021010001123200022010100101000100200 ? 000$ $3000103400110002102300021010001123200021010001101000100200 ? 000$ 30000030001100021013000210100011232000220101011010001002002000 $30001030001100021013020210100011232000220101011010001002002 * 00$ $300020341011000000230001101000112330002200 * 1021110001002002000$ 30002034001100000023000110100011333000220011021110001002002000 3000103400110000001300011010001123300022001101111000100200 ? 000 $3000203400110000002300001010001113100002000101111000100200 ? 000$ $3000203400110000002300001010001113100022000101111000100200 ? 000$ 3000203400110000002300011011001113100022010101101000100200 ? 000 30002030001100010012020110100011232000220101011010001002002000 $3000103000110002102300021010001123200022010101101000100200 ? 000$ $3000103000110002102300021010001223200022010101101000100200 ? 000$ 30000033001100000012000110100011233000220 ? 1 ? 011 ? ? 0 ? 010? ? 00 ? 000 30000015000100000012000200110111000010000100001001050112032101 $2000002310100000001000000111001212100010010000100100000200 ? 000$ $2000002310000000001000000111001212100010010010100000000200 ? 000$ $2100002310000000001010000111001111 ? 000100100101000000002003000$ 2100002310000000001010000111001111 ? 000100100101000000002003001 20000023100000000010000001110011121000000100101000000002002 ? ?? 21000023000000000010100000110011000000100 ? ? ? ? ? ? ? ? ? ? ? ? ? ? 3000001000000000001000000011001100001010010000100105011200 ?? ?? 30000012000100000012000000110011000010100100001001010112002101 30000023000000000010100000110012000010100100001001020112002101 30000034000000001021041210100010121000000100011000021432032000 30000030000000011011040210100011121000000100011000021432032000 30000030000000021010000210100011121000000100131000021432032000 $0020213000110 * 202101031210 * 0011222 * 00022110001101112150204$ ? 300 $002020300012002020110312102011112 * 2000321100020011111 * 0104$ ? 000 00202030001200202001031210201112212000321100020011111501042000 $20101030001100202011011210100012121000000100131011011002032 * 10$ $20101030001000 ? 02011011210100012121000000100101011011002032310$ 32001033001000000021000010100011121000000100023000011002002300 $3200103300100000002100001010001112100000010002200001100200 ? 200$ $3200103300100000001100001010001112100000010002300002100200 ? 000$ $320010-3001000000011000110100011121000010100123000021002002300$

* List of polymorphisms (terminal/character/states): Polistes $2(0,1) ; 43(0,1) ; 53(0,1) ; 60(0,3)$; Ropalidiini 2(0,1); 12(0,1); 13(0,1); 20(0,1); 28(0,1); $52(0,2)$; 58(0,4); immarginatus $40(1,2)$; mendax group $9(0,1)$; iperuae group $1(0,1) ; 10(0,1) ; 32(1,2)$; sylvestris $60(0,3)$; alboniger group $30(0,1)$; cassununga $60(0,2)$; pallidipectus $43(0,1)$; punctatus group $14(0,1) ; 27(2,3) ; 35(1,2)$; buyssoni group $34(1,3) ; 54(0,5)$; collarellus group $60(0,3)$ 
State 1 was observed in the species of the heliconius group, and in three species of Kappa.

11. Antennal sockets and adjacent areas of face and frons in the female: (0) frons looking depressed, scarcely swollen, antennal sockets close to each other, separated by distance no longer than their height, socket aperture facing well forwards, with an almost perfectly circular contour, its margin as a freely outstanding elevated lamella, interantennal area variably raised (Figs. 2, 141); (1) frons and upper portion of interantennal area more swollen and raised, socket aperture oriented more laterally, contour further apart of a circular shape, often angularly narrowed above, marginal lamella looking as if turned and compressed outwards (Figs. 1,3-4, 10-11, 142).

State 0 occurs in all the outgroup genera except Belonogaster. Within Mischocyttarus, it was observed in the subgenera Mischocyttarus s. str., Clypeopolybia (excepting the smaller species akin to M. richardsi), and Monogynoecus. State 1 occurs in all remaining groups in somewhat variously appearing conditions. In Kappa and most species of Phi, the interantennal area is comparatively wider and more raised, the upper portion shaped as a sloping surface that is continuous with the frontal region. In Megacanthopus and in the groups of M. cerberus, M. surinamensis, M. prominulus, and most of the artifex group, the interantennal area tends to be much more planar and vertical, presumably correlated with a narrower less swollen clypeus. But the rather subtle nature of the variation in form, and the occurrence of intermediate shapes restrict the recognition of additional states.

12. Distance between posterior ocelli: $(\mathbf{0})$ posterior ocelli distinctly approximated, often separated by less than one diameter; (1) posterior ocelli well-separated (but not exaggeratedly) by more than one diameter, the three ocelli positioned as the vertices of an equilateral triangle; (2) posterior ocelli separated by nearly two (or more) diameters, the three ocelli distinctly positioned as the vertices of a low triangle. (Ordered 0-1-2)

State 1 occurs in Polistes and Ropalidia, and in various groups within Mischocyttarus, typically in the subgenus Phi. State 0 also has a wide distribution. State 2 is observed only in part of Kappa and part of Omega.

13. Hairs on the eye of the female: (0) eye with sparse and very short hairs, not or scarcely visible at the dissection microscope; (1) eye with more numerous and longer hairs, distinct at the dissection microscope even at medium magnification.

In the outgroup genera, state 1 could be observed in some species of Ropalidia, in Agelaia and Apoica. Within Mischocyttarus, it occurs in a few species of Kappa, and of the surinamensis and prominulus groups.

14. Anterior face of the mandible in the female: (0) distal portion of the anterior face of the mandible without a prominent external edge, the transition between the anterior and lateral

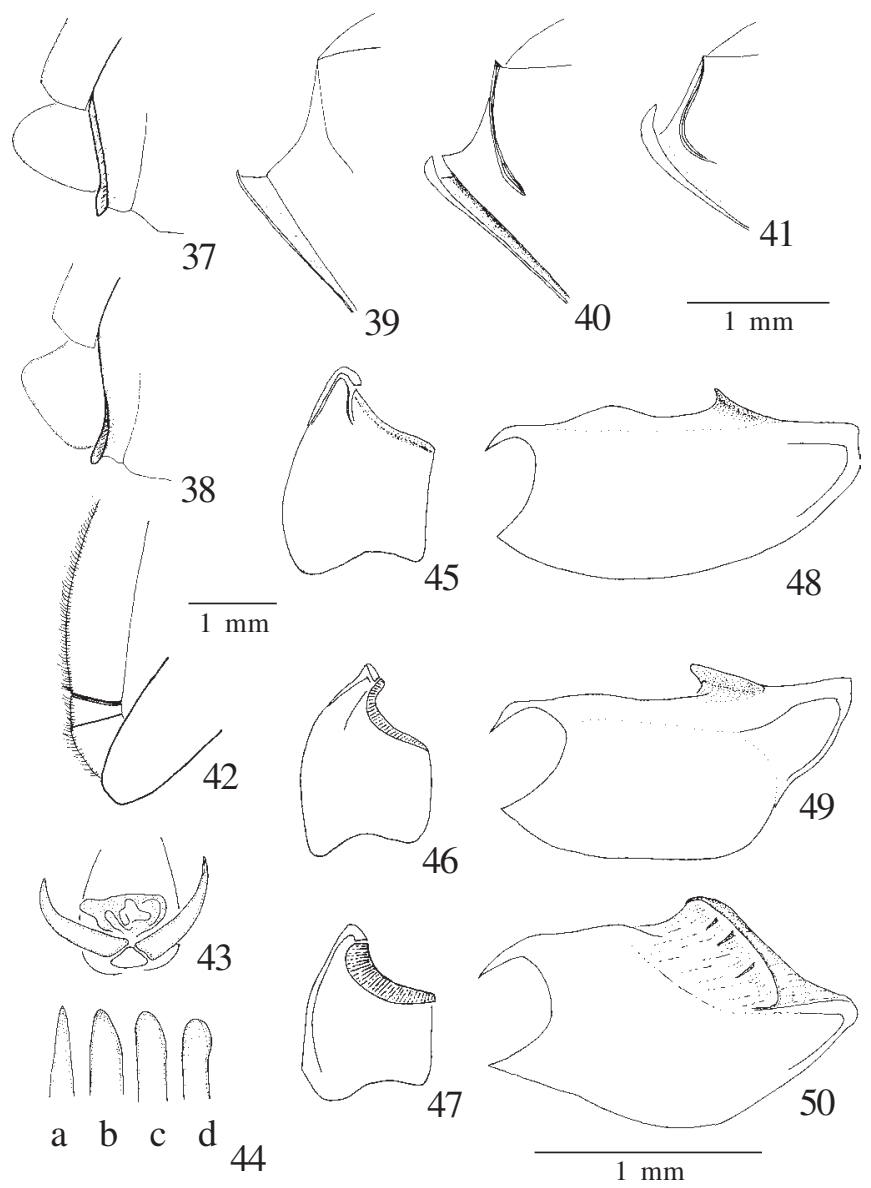

Figs. 37-50. Aspect of mesoscutal lamella in 37, M. flavitarsis; 38, M. carbonarius; lateral aspect of pronotum in 39, M. flavitarsis; 40, $M$. reflexicollis; 41, M. (Omega) sp. (MPEG); basal ring-like sulcus on femur in 42, M. carbonarius; last hind tarsal segment and claw in 43, M. lecointei; apex of inner hind tarsal claw in 44a, M. aripuanaensis; 44b, M. carbonarius; 44c, M. wygodzinskyi; 44d, M. interjectus; ventral aspect of proepisternum in 45, M. sylvestris; 46, M. montei; 47, M. confuses; lateral aspect of female coxa in 48, M. labiatus; 49, M. flavitarsis; 50, M. laurae.

main surfaces appearing rounded and continuous in apical view; (1) distal portion of the anterior face of the mandible with a prominent external edge, distinct in apical view (Fig. 22).

State 1 was observed in the Kappa species $M$. immarginatus, $M$. tolensis and $M$. laurae, and in a few forms of the punctatus group of subgenus Omega.

\section{MESOSOMA}

15. Anterior margin of the pronotum: (0) margin with the lamella not reflexed (Fig.39); (1) margin with the lamella reflexed (not more than 180 degrees) (Fig. 40); (2) margin with the lamella wide and strongly reflexed, especially at the center (more than 180 degrees) (Figs. 41, 52, 55-56, 58, 144). (Ordered 0-1-2)

State 2 is an extreme condition with a rather narrow distribution, occurring in the subgenus Omega (Monacanthocnemis of Richards, 1978), and in the prominulus 
group and part of the surinamensis group. A similar form was observed in most species of Megacanthopus, represented in the analysis by M. collarelllus. In Megacanthopus, however, the shape of the lamella seems to be correlated with the presence of a lateral spine that is unique within the genus Mischocyttarus (Fig. 56). Cooper (1997b) recently described $M$. inexpectatus, which lacks several apomorphies typical of the collarellus group as well as of Megacanthopus sensu Richards (1978). In spite of the very characteristic pronotal carina, clearly indicating a close relationship with remaining Megacanthopus species, $M$. inexpectatus does not present a lateral pronotal spine, and the anteromedian lamella is not typically wide and reflexed (Cooper's figure 1). Because this species could not actually be examined, the state in terminal "malaris group" was coded as ambiguous ("?"). State 1 is an intermediate condition observed in several Haplometrobius groups (sensu Richards, 1978), and in M. laurae.

16. Secondary margin behind the anteromedian lamella of the pronotum: (0) absent (Figs. 39, 41); (1) present as a low obtuse carina not projecting forwards; (2) present as a high acute carina strongly projecting forwards (Fig. 40). (Ordered $0-1-2)$

This character was widely used by Richards (1978) in the recognition of species-groups, especially in $P h i$ and Haplometrobius. However, it is highly homoplasious.

17. Anterior margin of the proepisternum: (0) margin low, not reflexed, lateral portion shaped as a narrow collar without an acute border directed backwards (Fig. 45); (1) margin low, not reflexed, lateral portion shaped as a wider collar with an acute border directed backwards, but not really detached or raised (Fig. 46); (2) margin elevated and strongly reflexed, lateral collar very wide and quite freely detached (Fig. 47). (Ordered $0-1-2)$

State 0 occurs in the outgroup genera, and in Mischocyttarus s. str., Clypeopolybia, Scytokeraia and some species of Phi and Haplometrobius (sensu Richards, 1978). State 1 is observed in Monogynoecus, most species of Phi and Haplometrobius, and in M. laurae. State 2 occurs in Megacanthopus, Omega and Kappa, and a few groups of Haplometrobius (sensu Richards, 1978).

18. Pre-marginal raised crest on proepisternum ("doublemargined" condition of Richards, 1978): (0) absent; (1) present.

State 1 occurs only in $M$. (Kappa) immarginatus and in the punctatus group of the subgenus Omega.

19. Pronotal carina at sides: (0) lamellate and extending downwards; (1) lamellate not extending downwards; (2) obtuse, lamella reduced (Fig. 143). (Ordered 0-1-2)

State 2 has a scattered distribution, certainly the result of multiple origins, but it is probably useful in the recognition of less inclusive groups. One can see the reduced condition in part of Phi, part of Scytokeraia, in M. (Kappa) immarginatus, and in the lecointei group of the subgenus Monogynoecus.

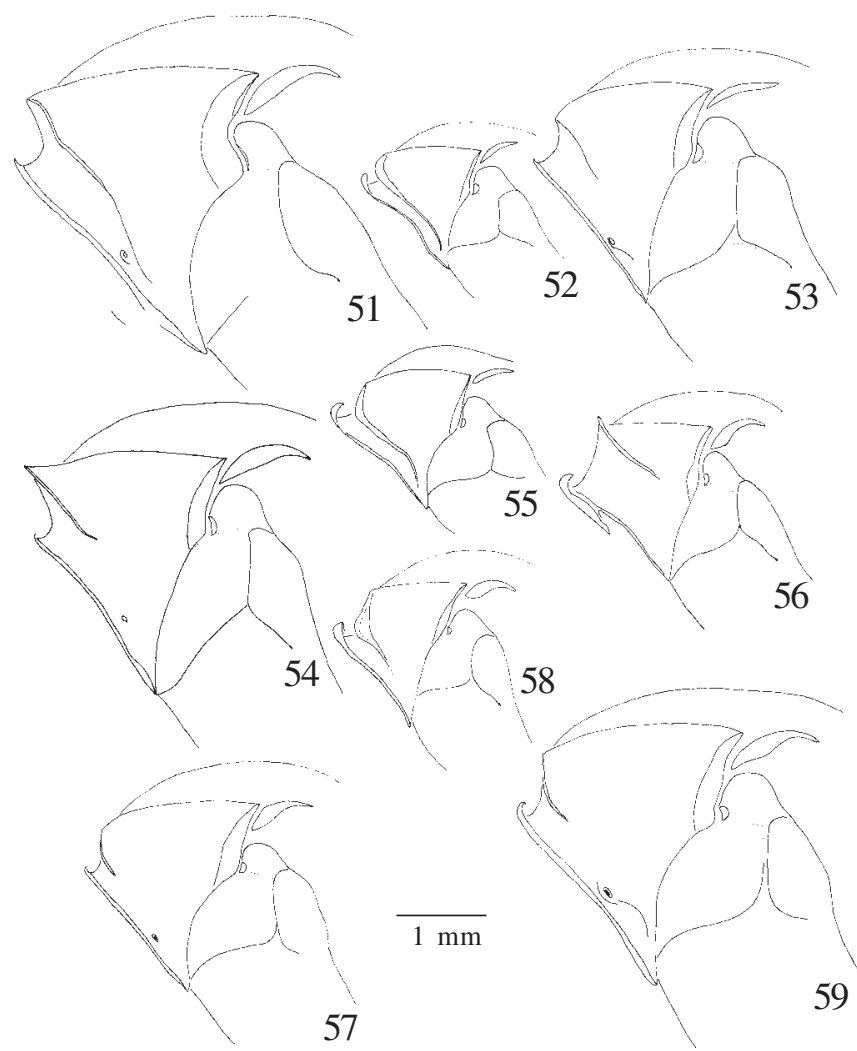

Figs. 51-59. Lateral aspect of pronotum and mesopleuron in 51, Polistes testaceicolor; 52, M. (Omega) sp. (NHM); 53, M. flavitarsis; 54, M. flavicans; 55, M. (Omega) sp. (UCDC); 56, M. saturatus; 57, M. metathoracicus; 58, M. filiformis; 59, M. laurae.

20. Central portion of the pronotal carina: (0) carina well developed, angularly raised at the center; (1) carina evenly raised from side to side; (2) carina partially reduced at center, without a distinct lamella but its linear course still perceptible; (3) carina completely reduced at center. (Ordered 0-1-2-3)

State 2 occurs typically in part of the species of $P h i$, but similar conditions are observable in $M$. drewseni and M. acunai (subgenus Mischocyttarus s. str.), and the two unrelated species $M$. interruptus (artifex group) and $M$. weyrauchi (iheringi group). State 3 also occurs in Phi, and in all species of Kappa.

21. Slope of the antero-dorsal part of the pronotum (including carina) in lateral view: (0) nearly vertical (Fig. 53, 56, 57, 59); (1) with a strong negative slope, antero-dorsal face distinctly projecting forwards as a roof over the region of the anterior margin (Fig. 51, 54).

Within Mischocyttarus, state 1 was observed only in the larger species of Clypeopolybia (M. flavicans and $M$. carbonarius), and two species of Mischocyttarus s. str. (M. aripuanaensis and $M$. tomentosus). A similar but certainly unrelated form was observed in one species of Polistes (Fig. 51).

22. Humeral region of the pronotum: (0) well developed, 
angular but without a prominent lobe (Fig. 60); (1) humeral region with a distinctly rounded contour (Fig. 61); (2) with well developed and laterally produced lobe (Fig. 62); (3) with greatly developed lobe projecting forwards (Fig. 63); (4) humeral region strongly reduced, its contour seen from above nearly continuous with the anterior region of the pronotum (Fig. 64). (Unordered)

State 0 occurs in almost all of the outgroup genera, with the exception of Polybioides where the humeral region is strongly reduced and the pronotal carina is completely absent, this being an autapomorphy of the genus. In Belonogaster, which also lacks a pronotal carina, the humeral region is more produced and angular, a feature corresponding well to state 0 . States 1 is an autapomorphy of Megacanthopus, state 3 is typically observed in subgenus Omega (Monacanthocnemis of Richards, 1978), and state 4 is observed in most species of Monogynoecus.

23. Pronotal fovea: (0) present; (1) absent.

State 0 occurs primitively in most of the outgroup genera, with exception of Ropalidia and Belonogaster. State 1 had probably at least two independent origins in Mischocyttarus.

24. Inner margin of the anterior coxa. (0) very low (Fig. 48); (1) more raised but weakly reflexed (Fig. 49); (2) raised and strongly reflexed (Fig. 50). (Ordered 0-1-2)

This was one of the two main characters used by Richards (1978: 273; first dichotomy of the key for the Mischocyttarus subgenera) to differentiate Mischocyttarus s. str. and Clypeopolybia from the remaining subgenera. Richards did not notice (neither did Cooper, 1997a) that state 0 occurs in $M$. mastigophorus and related species, as well as in some $P h i$ species like $M$. hirtulus and $M$. spadiceus Zikán (= M. commixtus Richards). Furthermore, in some other species of Phi, such as M. flavitarsis, M. pallidipectus, and $M$. marginatus the margin of the anterior coxa presents an intermediate condition here referred to as state 1 . Finally, to make things worse, M. acunai, considered by Richards (1978) as part of Monocyttarus (= Phi), but an evident member of Mischocyttarus s. str. (see Silveira, 2002) has a raised and reflexed inner margin. This character has a far more complicated distribution than previously considered by other authors.

25. Ring-like sulcus on the base of the fore and mid femora: (0) present (Fig. 42); (1) absent.

This is the other main character used by Richards (1978) to distinguish Mischocyttarus s. str. and Clypeopolybia from the remaining subgenera. State 0 occurs in the outgroup, in all species of Mischocyttarus s. str., and in Clypeopolybia sensu Silveira (1998). State 1 is then a putative synapomorphy of a major clade comprising all remaining groups of Mischocyttarus, including the heliconius group of Richards (1945). It is indeed intriguing that, given the perfectly consistent distribution of this character, Richards (1978) nevertheless decided to include $M$. heliconius and related species (that lack a basal sulcus) in Clypeopolybia.

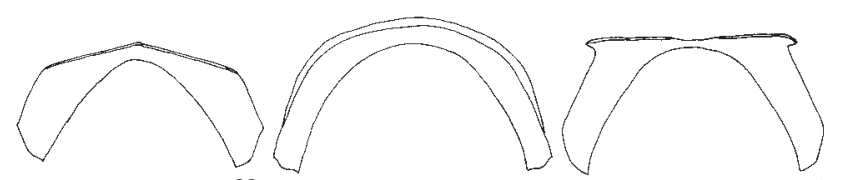

60

61

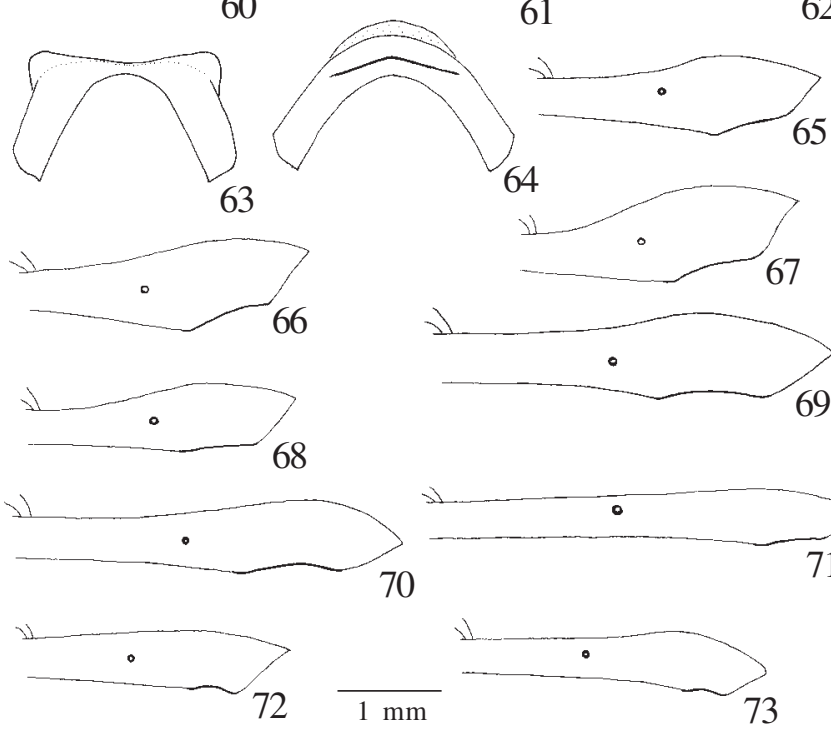

Figs. 60-73. Dorsal aspect of pronotum in 60, M. (Monogynoecus) sp. (INPA); 61, M. saturatus; 62, M. weyrauchi; 63, M. (Omega) sp. (NHM); 64, M. foveatus; lateral aspect of first metasomal segment in 65, $M$. mastigophorus; 66, M. lecointei; 67, Mischocyttarus sp. gr. heliconius (MPEG); 68, M. cassununga; 69, M. mexicanus; 70, M. basimacula; 71, M. filiformis; 72, M. buyssoni; 73, M. (Omega) sp. (MPEG).

26. Fore femur in the female: $(\mathbf{0})$ fore femur in section with a roughly round contour, not noticeably flattened posteriorly; (1) fore femur with its posterior surface strongly flattened, with a longitudinal sharp edge ventrally, this sometimes appearing "lamellate".

State 1 is an extreme condition occurring in Clypeopolybia only. A moderate degree of flattening could be observed in a few species of Mischocyttarus s. str., Phi, and Kappa.

27. Pronotum and mesopleuron in lateral view: (0) posterior margin of the pronotum laterally strongly curved below the pronotal tubercle, the ventral angle being positioned just below the tubercle; dorsal mesepisternal plate oblique, pleuron not strongly protuberant (Fig. 51); (1) posterior margin of the pronotum laterally nearly straight below the pronotal tubercle, the ventral angle being in a more anterior position; dorsal mesepisternal plate oblique, pleuron not strongly protuberant; humeral region short, distance between the extremity of the pronotal carina and tubercle equal to or less than the distance between the latter and the posterior angle of the pronotum (Figs. 53, 54, 56); (2) posterior margin of the pronotum laterally nearly straight below the pronotal tubercle, the ventral angle being in a more anterior position; dorsal mesepisternal plate shortened below, pleuron strongly protuberant; humeral region short, distance between the extremity of the pronotal carina 
and tubercle equal to or less than the distance between the latter and the posterior angle of the pronotum (Figs. 52, 58); (3) posterior margin of the pronotum laterally strongly curved below the pronotal tubercle, the ventral angle, however, being in a position more anterior than that of the tubercle; dorsal mesepisternal plate wide and "horizontal", pleuron strongly protuberant; humeral region longer, distance between the extremity of the pronotal carina and tubercle clearly longer than the distance between the latter and the posterior angle of the pronotum (Figs. 55, 57, 59). (Unordered)

State 0 occurs only in the outgroup genera, being typically observed in Polistes. State 1 is a putative synapomorphy of Mischocyttarus as a whole, and states 2 and 3 are putative synapomorphies respectively of Omega (Monacanthocnemis of Richards, 1978) and Kappa, but one form in the punctatus group of Omega (a female from Panamá; UCDC, Bohart Museum) presents a morphology similar to the condition observed in Kappa species. So the punctatus group is scored as polymorphic for this character.

28. Margin of the mesoscutum adjacent to tegula: (0) with a complete laterally projecting margin (Fig. 37); (1) anterior two-thirds of the margin reduced (Fig. 38).

State 0 occurs primitively in Polistes and the other genera of the outgroup, with the exception of Ropalidia and Parapolybia. In Mischocyttarus it can be observed in a great majority of groups and species. State 1 occurs typically in Mischocyttarus s. str. and Clypeopolybia, but similar forms were observed in the Phi species M. tarmensis, and $M$. spadiceus Zikán (= M. commixtus Richards).

29. Number of spurs on mid-tibia: (0) two; (1) one.

State 1 is a putative synapomorphy of a clade comprising most species of Omega (Monacanthocnemis of Richards, 1978) except those of the punctatus group.

30. Ventral surface of the hind femur in the female: $(\mathbf{0})$ surface planar or slightly round; (1) surface with a shallow longitudinal sulcus.

State 1 is observed in M. acunai, in all species of Omega (Monacanthocnemis of Richards, 1978) and in part of Kappa, and also in some forms of the prominulus group represented in the analysis by the terminal "alboniger group".

31. Symmetry of tarsal inner and outer lobes: (0) tarsal segments with symmetric lobes; (1) tarsal segments with asymmetric lobes, the inner one larger.

State 1 is a putative synapomorphy of the genus Mischocyttarus.

32. Hind tarsal claws: (0) symmetric or nearly, sharply pointed (Fig. 43); (1) asymmetric, the internal one larger and presenting the apex sharp or narrowly pointed (Figs. 44 a and b); (2) asymmetric, the internal one larger and presenting the apex wide and rounded (Figs. $44 \mathrm{c}$ and d). (Ordered 0-1-2)

State 0 occurs in the outgroup, and in the group of $M$.
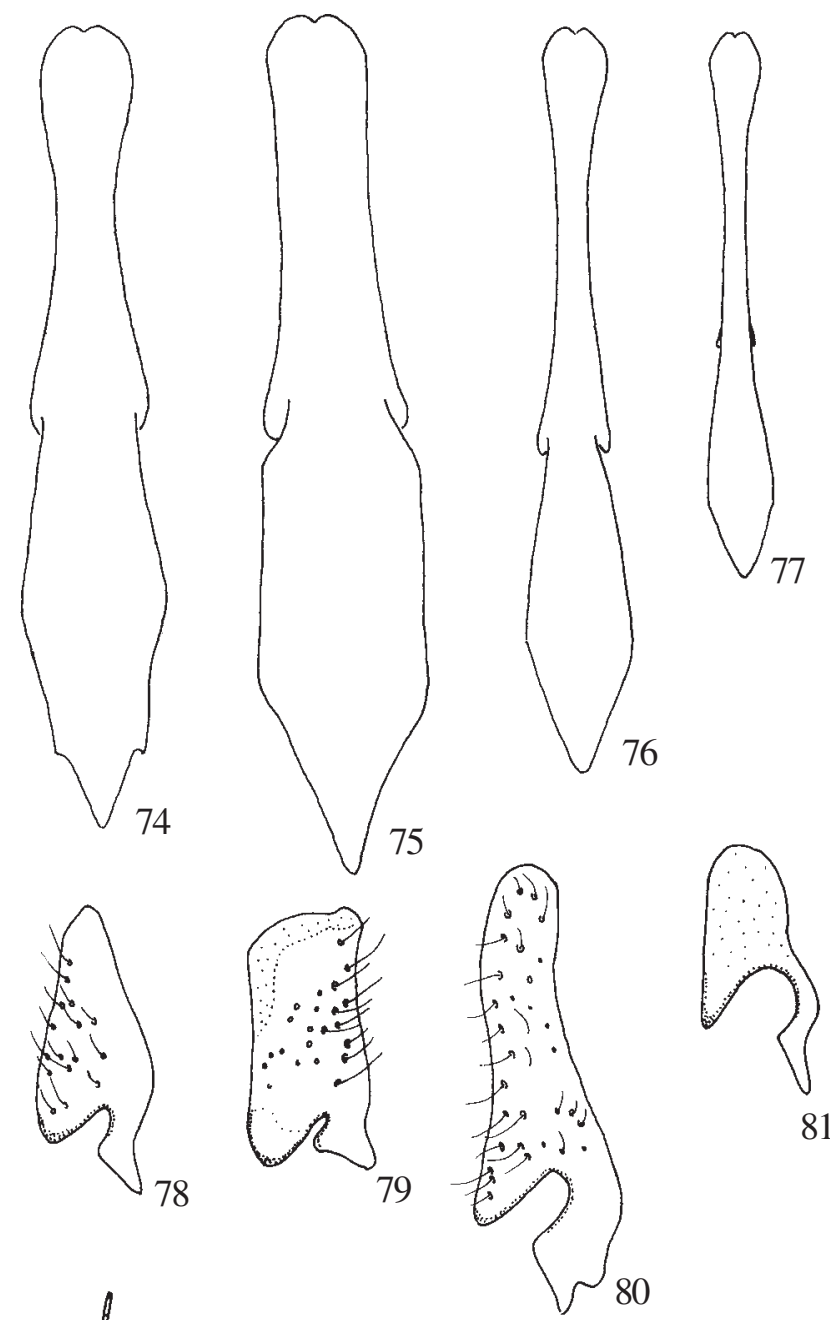

81
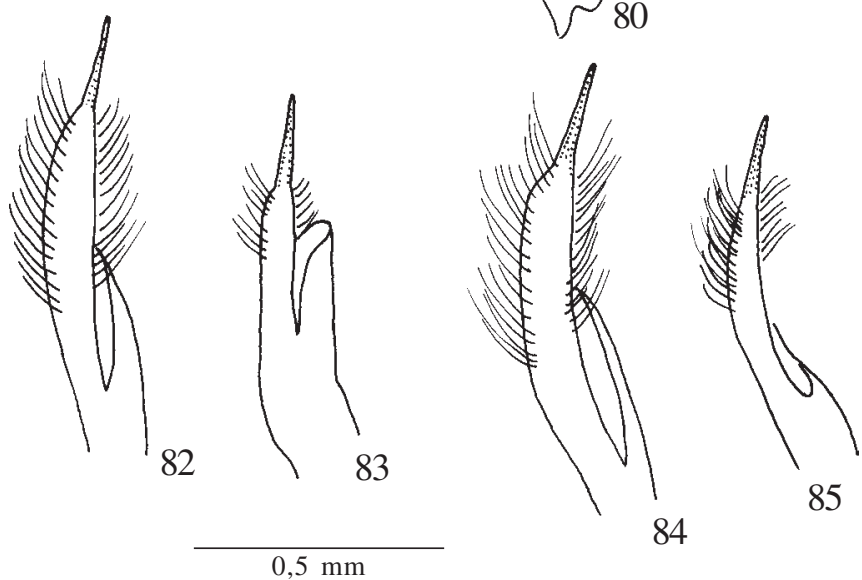

Figs. 74-85. Male aedeagus in 74, M. drewseni; 75, M. acunai; 76, M. duckei; 77, M. mastigophorus; male digitus in 78, M. drewseni; 79, M. acunai; 80, M. flavicans; 81, M. mastigophorus; male parameral spine in 82, M. drewseni; 83, M. acunai; 84, M. flavicans; 85, M. mastigophorus.

lecointei of subgenus Monogynoecus. None of the other two states present consistent distributions, but state 1 most often occurrs in the subgenera Mischocyttarus s. str., Clypeopolybia, Monogynoecus, Scytokeraia, Phi, and 
Kappa, whereas state 2 is more frequently observed in the subgenera Megacanthopus, Haplometrobius, and Omega.

33. Shape of propodeum: $(\mathbf{0})$ with anterior medial surface raised and "horizontal", planar at sides and without lateral posterior concavity; (1) with anterior medial surface not noticeably raised, oblique, lateral surface planar and without lateral posterior concavity; (2) anterior medial surface not noticeably raised, oblique, lateral surface inflated and with lateral posterior concavity; (3) with anterior medial surface raised and "horizontal", lateral surface inflated and with lateral posterior concavity. (Ordered 0-1-2-3)

State 0 is restricted to Mischocyttarus s. str. State 1 is observed in the outgroups and various subgenera and speciesgroups within Mischocyttarus, whereas 2 and 3 are generally observed in Phi and Kappa respectively.

34. Propodeal median furrow: (0) deep and triangular; (1) deep and linear; (2) shallow linear or absent; (3) wide and triangular. (Ordered 0-1-2-3)

State 0 is restricted to Mischocyttarus s. str. and state 1 is observed in the two Clypeopolybia species M. flavicans and $M$. carbonarius. State 2 occurs in the outgroups and various subgenera and species-groups within Mischocyttarus, while 3 is generally observed in Phi and Kappa.

35. Shape of metanotum: (0) transversal; (1) triangular and flattened or very low; (2) triangular and moderately convex; (3) triangular and strongly convex. (Ordered 0-1-2-3)

State 0 occurs in Polistes and in Mischocyttarus s. str. State 1 occurs is the smaller species of Clypeopolybia and in several other species-groups in Mischocyttarus. State 2 occurs in most Phi species and in Omega (Monacanthocnemis of Richards, 1978), whereas state 3 was observed in all species of Kappa and some of Phi, related to M.flavitarsis. Shape of the propodeum is variable "within" the two Clypeopolybia species $M$. flavicans and $M$. carbonarius, and was then considered inapplicable in these cases. Such was also the treatment given to ropalidiines and epiponines where considerable variation exists between species, with shapes evidently unrelated to those observed in Mischocyttarus.

36. Upper edge of the propodeal lateral posterior concavity: (0) smoothly rounded, edge not actually defined (Figs. 165166); (1) upper edge well defined and sharp, continuous with the posterior margin of the propodeum adjacent to valvular region, clearly separating the lateral concavity from the central dorsal portion of the propodeum (Figs. 167).

State 1 occurs exclusively and in most species of Kappa, being absent only in $M$. immarginatus and in M. laurae.

\section{METASOMA}

37. Metasoma in cross section: (0) with a circular or dorsoventrally flattened contour; (1) narrow, with a laterally compressed contour.

State 1 was found in most species of Mischocyttarus s.
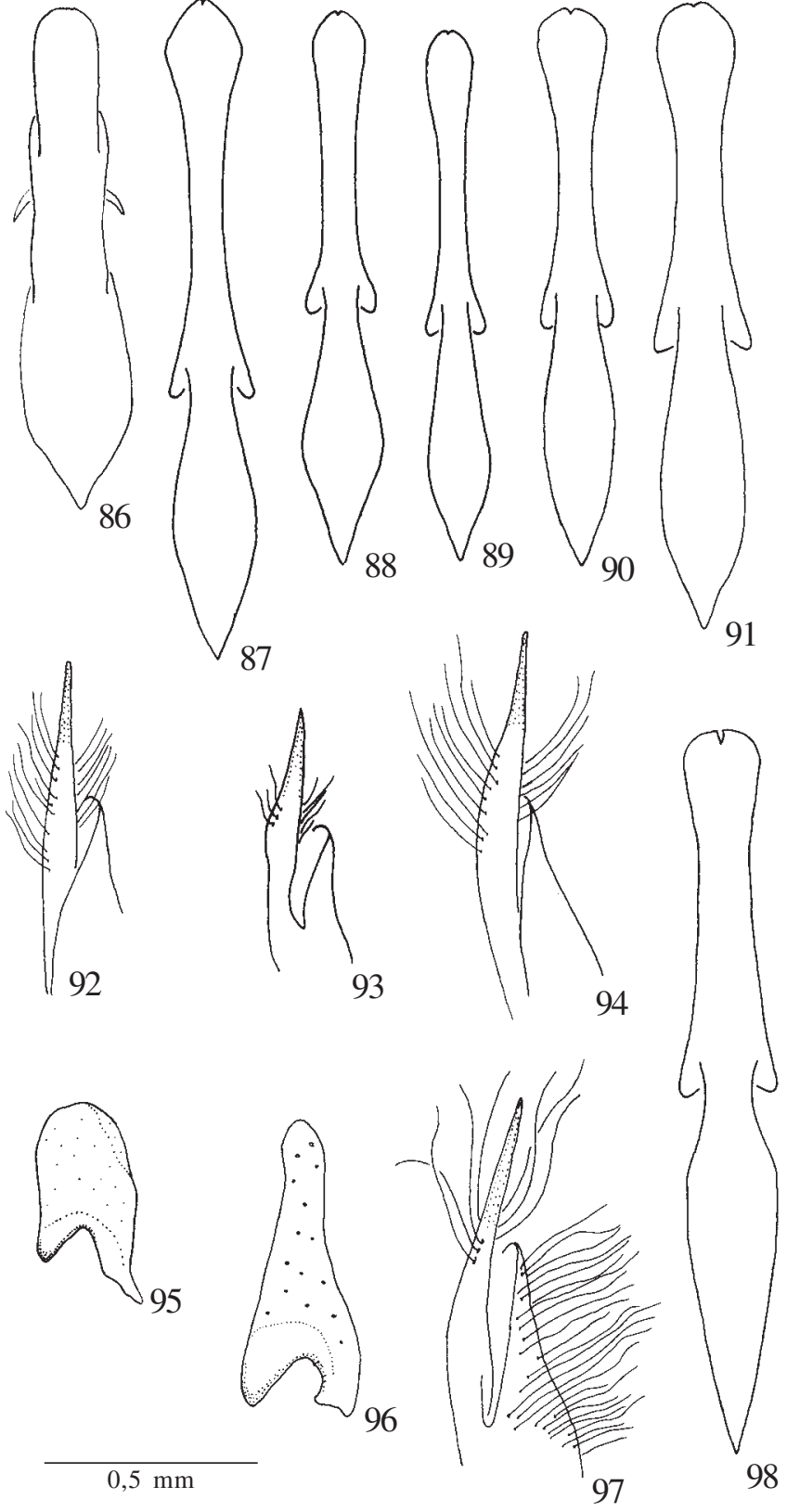

Figs. 86-98. Male aedeagus in 86, M. (Monogynoecus) sp. (MPEG); 87, M. marginatus; 88, M. alfkenii; 89, M.extinctus; 90, M. bertonii; 91, M. tolensis; 98, M. immarginatus; male parameral spine in 92, M. extinctus; 93, M. (Monogynoecus) sp. (MPEG); 94, M. marginatus; 97, M. immarginatus; male digitus in 95, M. (Monogynoecus) sp. (MPEG); 96, M. immarginatus.

str., which typically have an elongate first metasomal segment.

38. Lateral aspect of petiolar portion of the first metasomal segment: (0) limit between tergum and sternum rounded, sometimes demarcated by a sulcus; (1) limit between tergum and sternum produced into a prominent shining edge, sternum distinctly flattened.

State 1 is a putative synapomorphy of a clade comprising 
most species of Kappa, being absent only in $M$. immarginatus and M. laurae.

39. General shape of the first metasomal segment: $(\mathbf{0})$ profile of the segment with a distinct ventral angle at a point positioned posteriorly to the spiracle, tergal margins not too closely approximated below at this point, distal portion of the segment in lateral view oriented obliquely "upwards" (Figs. 65-67); (1) segment strongly compressed, its profile very deep ventrally with a quite prominent ventral angle positioned posteriorly to the spiracle, tergal margins closely approximated ventrally at this point, so that the sternum has a constricted appearance, distal portion of the segment in lateral view oriented obliquely "upwards"; (2) segment with a shallow profile, ventrally with a poorly developed angle at a point positioned posteriorly to the spiracle, tergal margins not noticeably approximated at this point, distal portion of the segment lengthened backwards and oriented in line with the petiole, the distal expanded portion of the sternum in lateral view always longer than a distance measured in forward direction from the beginning of the expanded part up to the spiracle (Figs. 68-70); (3) segment long and very narrow, even distally, its profile sometimes slightly curved downwards, no ventral angle posterior to the spiracle, but distal portion of the segment not noticeably lengthened backwards, the distal portion of the sternum in lateral view shorter than a distance measured in forward direction from the beginning of the expanded part up to the spiracle (Figs. 71-73). (Unordered)

In spite of the distinct "subsessile" aspect of the first metasomal segment in Polistes, the condition in this genus is considered equivalent to state 0 found in other outgroup genera and in various groups within Mischocyttarus. In Ropalidia the shape of the segment seems highly variable, being in some instances very similar to that typically observed in Polistes. In these cases, the fundamental aspect considered was the presence of a ventral angle in the profile of the segment situated posteriorly to the spiracle. State 1 is characterized by the compressed aspect of the ventral part of the segment, occurring in Mischocyttarus s. str. and part of Clypeopolybia. Sate 2 occurs in the subgenera Phi, Kappa, and in the punctatus group of Omega (Monacanthocnemis of Richards, 1978). State 3 was found only in the remaining species of Omega.

40. Lateral margin of the distal expanded portion of the first metasomal sternum: (0) margin raised and sharp (Fig. 170); (1) margin reduced for the most part, sharp only on its distal extremity; (2) margin completely reduced (Figs. 171-172). (Ordered 0-1-2)

State 0 occurs in the outgroup genera and in most groups of Mischocyttarus. States 1 and 2 occur in Phi, in most of the species of Kappa, and in Omega (Monacanthocnemis of Richards, 1978). The intermediate state 1 , however, could also be observed in the prominulus group, and in some species of Scytokeraia, like M. alienus.

41. Hairs and tegument of the basal portion of the first

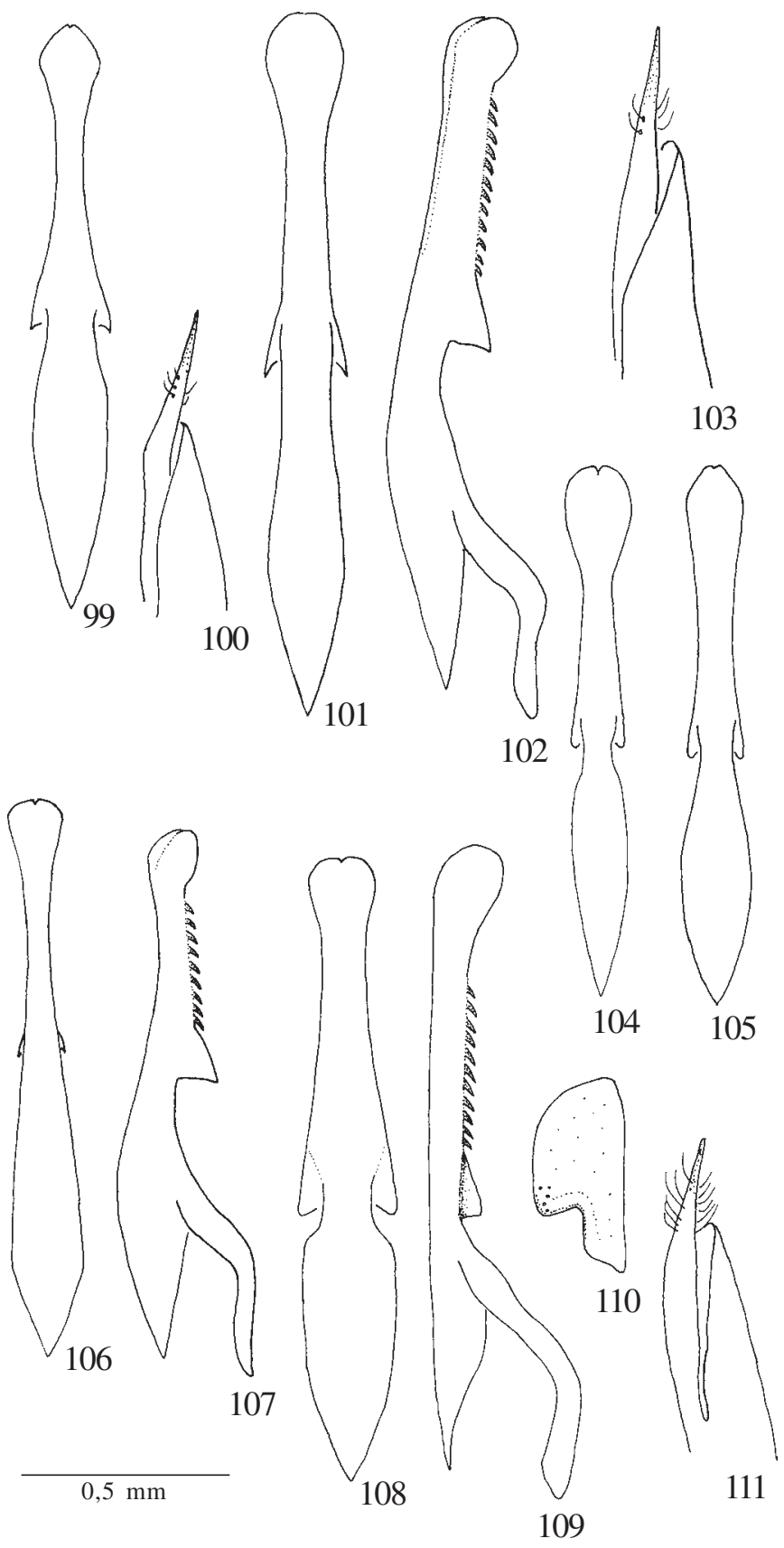

Figs. 99-111. Male aedeagus dorsal in 99, Mischocyttarus sp. gr. artifex (MZSP); 101, M. artifex; 104, M. weyrauchi; 105, M. cooperi; 106, M. interjectus; 108, M. nigropygialis; male aedeagus lateral in 102, M. artifex; 107, M. synoecus; 109, M. nigropygialis; male parameral spine in 100, Mischocyttarus sp. gr. artifex (MZSP); 103, M. artifex; 111, M. nigropygialis; male digitus in $M$. nigropygialis.

metasomal sternum: (0) sternum with a dense cover of short hairs, also presenting longer more scattered ones; (1) sternum without a dense cover of short hairs, tegument shining, with few and scattered long hairs (Figs. 168-169).

State 1 occurs in part of the species of the prominulus group, and in subgenus Omega (Monacanthocnemis of Richards, 1978). 


\section{MALECHARACTERS}

42. Width of gena in the male: $(\mathbf{0})$ wide, similar to condition in the female; (1) distinctly narrower than in the female.

State 0 occurs in Polistes, Belonogaster, and in a few species of the flavitarsis group of Phi. State 1 is the prevalent condition both in the outgroup genera and within Mischocyttarus, being certainly the primitive state in the genus.

43. Separation between clypeus and eye in the male: (0) contiguous; (1) separate.

Some species in Polistes, especially in the subgenus Aphanilopterus, present a narrow separation between clypeus and eye in the male, but the primitive condition in the genus is that in which the two structures are contiguous (Carpenter, 1996). In Mischocyttarus, state 1 could be observed in some species of subgenus Phi.

44. Tyloids on the ventral surface of flagellomeres of the male antenna: (0) well defined, elongate, with rectangular or oval shape (Figs. 145-155, 157-158); (1) present but smaller or very reduced, their limits imprecise, sometimes fragmented, not very shining (Figs. 156, 159-161); (2) absent. (Ordered 0-1-2)

Antennal tyloids appear at the dissection microscope as areas with a different texture, often more raised and shining than circumjacent areas of the flagellomeres. At the scanning microscope they are characterized by the absence (or extreme rarity) of placoid sensilla and also of those bristle-like sensilla with spiraled cuticular patterns typical of other zones of the flagellomeres. This may be seen especially in figures 146 and 149 showing in detail the limit between tyloid and circumjacent area in Ropalidia romandi and Mischocyttarus (Scytokeraia) mastigophorus. State 1 occurs in the great majority of Phi species, with the only noted exception of M. extinctus (Fig. 158). In some species of Ropalidia and Polybioides, tyloids may be quite small, with a circular shape, but they also have a more raised and shining aspect than in Phi species (Fig. 146). Furthermore, according to currently accepted relationships among the basal lineages of Polistinae (Carpenter, 1991, 1993), the occurrence of well developed tyloids in Polistes, Parapolybia and Belonogaster indicate indeed that the conditions observed in Ropalidia and Polybioides are convergently derived. In some species of Kappa, the tyloids of basal segments appear reduced and fragmented, as in $M$. immarginatus (Fig. 156), but those on more distal segments have a normal aspect. The complete absence of tyloids in Apoica and Agelaia represents one of the autapomorphies of Epiponini (Carpenter, 1991).

45. Erect conspicuous hairs on the ventral surface of the flagellum of the male antenna: (0) absent (Figs. 145-147, 149150, 153, 156-161); (1) present (Figs. 148, 151-152, 154, 155).

Richards (1978) used the name "cilium" (pl. cilia) to refer to the hairs on the antenna of males specially in groups like Haplometrobius and Megacanthopus, in which hairs tend to be longer and more numerous. However, reasonably conspicuous erect hairs can be found in other groups too,
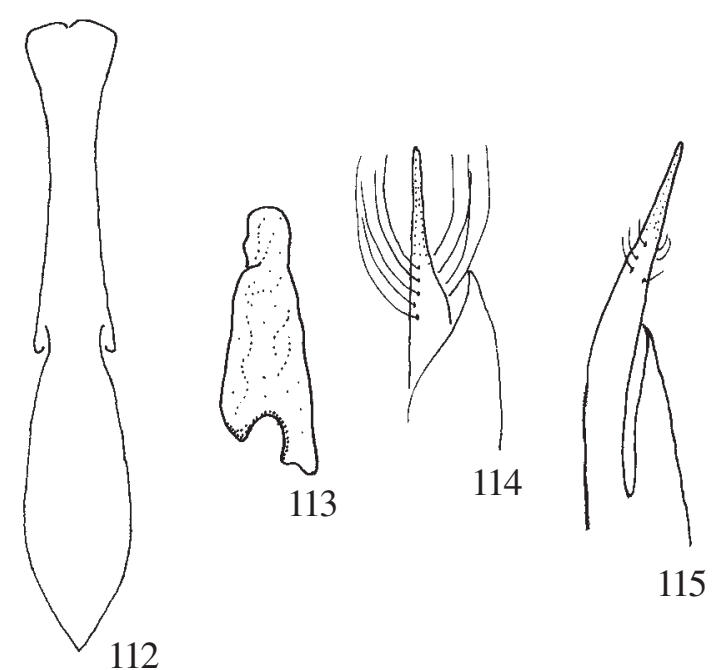

115
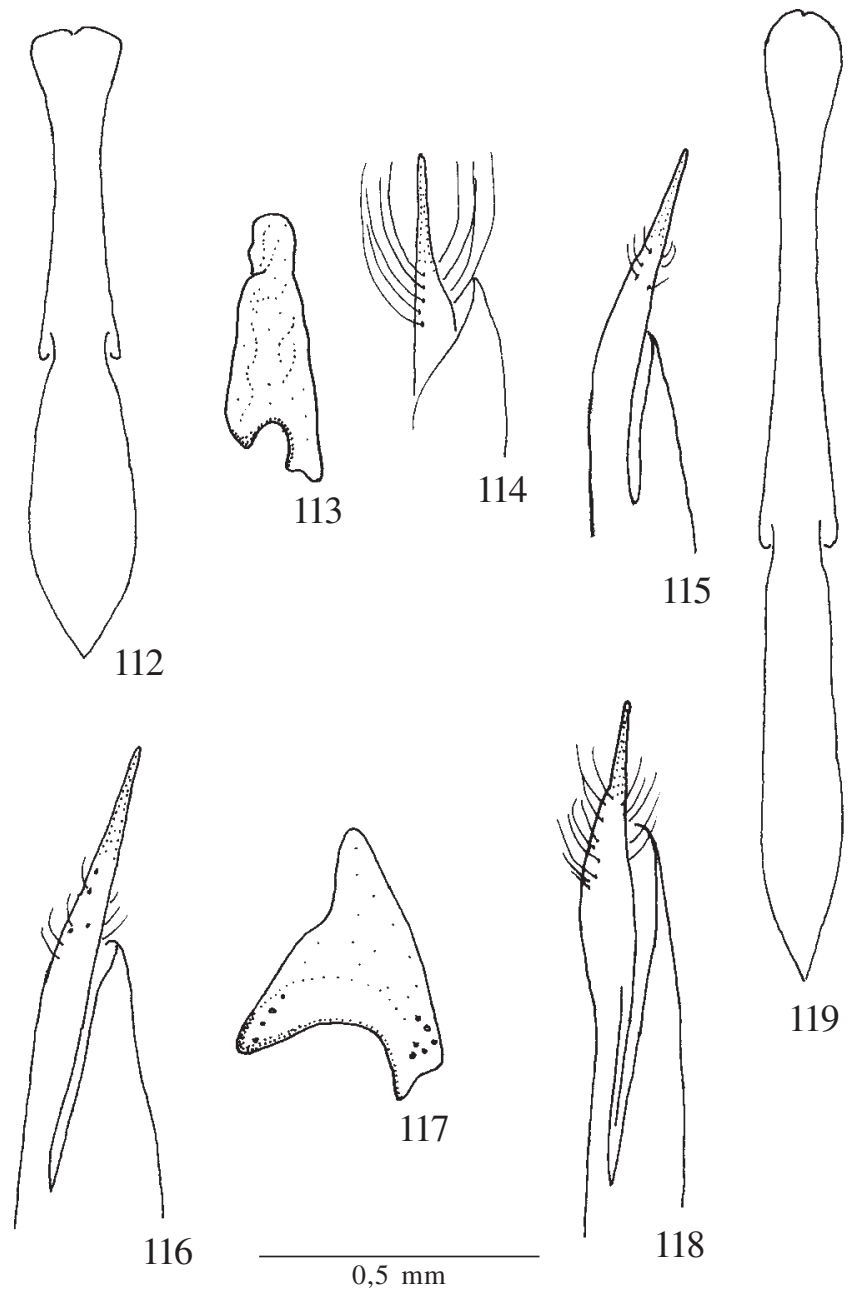

119

Figs. 112-119: Male aedeagus in 112, M. narinensis; 119, Mischocyttarus sp. gr. heliconius (MPEG); male digitus in 113, M. narinensis; 117, M. collarellus; male parameral spine in 114, M. narinensis; 115, M. reclusus; 116, Mischocyttarus sp. gr. heliconius (MPEG); 118, M. collarellus.

presenting a somewhat continuous variation in length and density of occurrence, making it difficult to recognize more than one "ciliate" state.

46. General shape of the antenna in the male: (0) antenna with an essentially linear shape, not much elongate, apical articles cylindrical, not much narrower than basal ones (Figs. $32,33,36)$; (1) antennal apex strongly shortened, with a hooklike shape, apical articles cylindrical, distinctly narrower than basal ones (Figs. 34-35); (2) antenna elongate, apical part very narrow and spirally rolled, apical segments cylindrical, distinctly longer than wide in dorsal view (Figs. 27, 29, 30, 31); (3) antenna moderately elongate, narrower at the apex, but with distal segments distinctly flattened below and not much longer than wide in dorsal view (Fig. 28). (Unordered)

State 0 occurs in the outgroup genera, in the subgenera Mischocyttarus s. str. and Clypeopolybia, and probably 
convergently in part of Megacanthopus. State 1 has a widespread occurrence in Mischocyttarus, and is present also in part of the outgroup genus Polistes. It tends to occur in most Monogynoecus and Phi species, but is also found in Kappa, and Haplometrobius and Omega (Monacanthocnemis of Richards, 1978). State 2 is likewise widely distributed, occurring in the outgroup genera Parapolybia and Belonogaster, and in the subgenera Scytokeraia, Phi, Kappa, Haplometrobius, and Omega. State 3 is typically observed in the artifex group and in most species of Megacanthopus, but a similar shape can also be observed in some species of Kappa and in one undescribed species of Monogynoecus (MPEG collection).

47. Article 13 of the antenna in the male: (0) narrow, laterally compressed, distinctly curved downwards (Figs. 30). (1) length variable, slightly flattened ventrally at the base, apex with a conical shape, dorsal profile curved (Figs. 31-36); (2) very long, straight, and laterally compressed (Fig. 29); (3) long or very long, straight, laterally compressed, distinctly tapering to the apex (Fig. 27); (Ordered 0-1-2-3)

State 1 represents a set of shapes not always very similar regarding general proportions, but it is assumed that such differences are the result of other more general differences related to variation in length of the antenna and diameter of the apical segments, and occurs in outgroups and most Mischocyttarus species. States 0, 2 an 3 are synapomorphies of some species-groups, state 0 being a putative synapomorphy between the filiformis and buyssoni groups of Omega, and states 2 and 3 occurring in Scytokeraia only.

48. Male mandible: (0) reasonably elongate and sclerotized; (1) very wide and robust, strongly sclerotized, apical tooth 4 (anteriormost) excessively developed and prominent (Figs. 19).

State 1 occurs only in some species of the flavitarsis group of subgenus Phi.

49. Apical tooth 1 (posterior-most) of the mandible in the male: (0) with external surface quite convex (similar to female), its posterior border curved (Figs. 23-24); (1) planar, distal portion often with a linear aspect, apex rounded, posterior border not really sharp and often with a concave profile (Fig. 18); (2) very long, much more than tooth 2 , plane, distal portion often with a linear aspect, apex rounded, posterior border not really sharp and often with a concave profile (Figs. 21, 26). (Ordered 0-1-2)

State 0 occurs in the outgroup genera, and in the subgenera Mischocyttarus s. str., Clypeopolybia, Monogynoecus, and Scytokeraia. State 1 occurs widely in the other groups of Mischocyttarus with few instances of noticeable variation in shape. In those species related to $M$. flavitarsis that have a wide and robust mandible, the tooth 1 has a more solid, less altered form than in remaining $P h i$ species. But its shape is not really similar to that in the female as in state 0 , and seems to be just a particular aspect of the extreme robustness of the mandible. In $M$. weyrauchi of the iheringi group, tooth 1 has

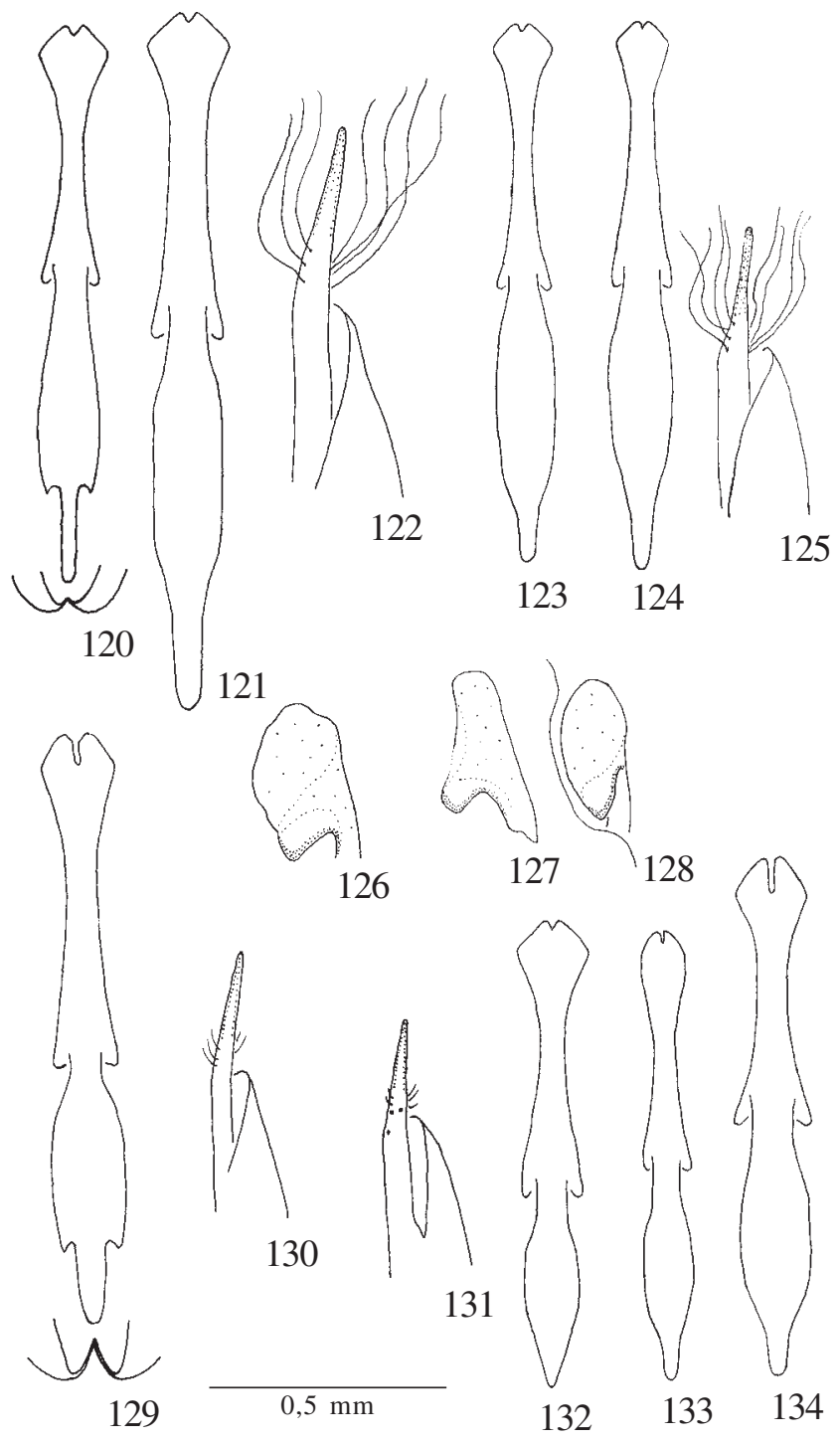

Figs. 120-134. Male aedeagus in 120, M. surinamensis; 121, Mischocyttarus sp. gr. surinamensis (UCDC); 123, M. silvicola; 124, Mischocyttarus sp. gr. alboniger (MPEG); 129, M. buyssoni; 132, M. (Omega) sp. (NHM); 133, M. (Omega) sp. (MPEG); 134, M. filiformis; male parameral spine in 122, Mischocyttarus sp. gr. surinamensis (UCDC); 125, Mischocyttarus sp. gr. alboniger (MPEG); 130, M. buyssoni, 131, M. (Omega) sp. (MPEG); male digitus in 126, M. silvicola; 127, Mischocyttarus sp. gr. surinamensis (UCDC) lateral; 128, same species ventral.

a quite pointed apex, and it is not as planar as in the other species presenting state 1 . However, in $M$. weyrauchi the posterior margin of the mandible has a strong angle that typically occurs in association with state 1 . State 2 is recognized by the extreme elongation of tooth 1 , and is observed in M. cerberus and M. dimorphus, most species of the artifex group, and in the species of Kappa.

50. Tooth 4 of the mandible in the male: (0) well developed (Figs. 18-20); (1) reduced (Figs. 21-26).

State 1 occurs in the subgenera Kappa, Haplometrobius, 

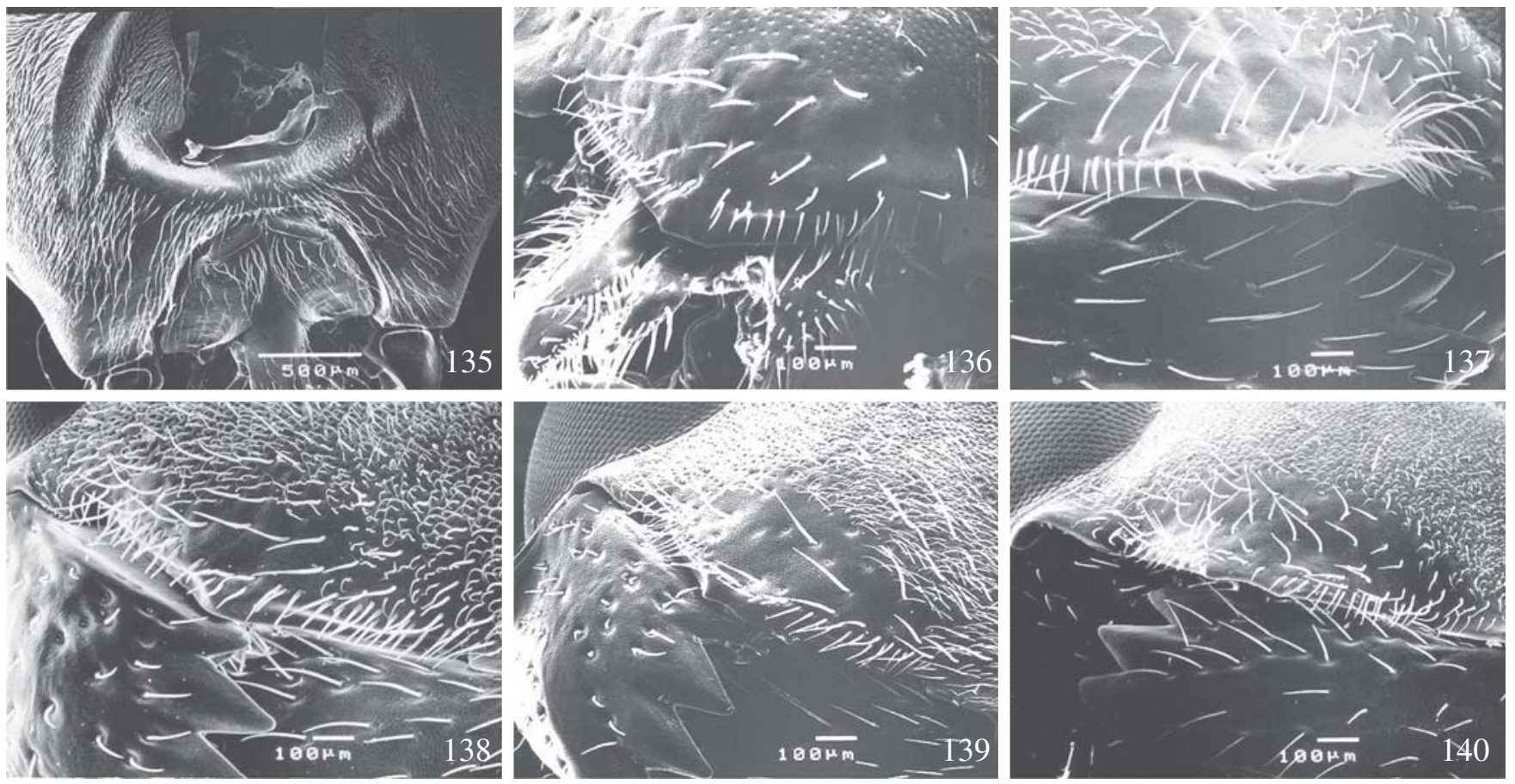

Figs. 135-140. (SEM). Posterior view of the head showing occipital foramen in M. imitator; apical view of female clypeus in 136, Polistes pacificus; 137, M. flavicans; 138, M. immarginatus; 139, M. mexicanus; 140, M. mastigophorus.

Megacanthopus, Omega, in the smaller species of Clypeopolybia (cf. M. richardsi, M. wygodzinskyi) and in Mischocyttarus s. str.

51. External surface of the fore coxa of the male: $(\mathbf{0})$ convex; (1) flattened.

State 1 occurs in Omega (Monacanthocnemis of Richards, 1978) and in part of the species of Kappa. In Omega, however, the flattened aspect is more accentuated, extending over the whole anterior leg.

52. Digitus of the male genitalia: (0) very long, distally with a finger-like shape (Figs. 80, 96); (1) not very long, triangular in lateral view (Figs. 78, 117); (2) very short, with a rounded shape (Figs. 81, 95, 110); (3) not very long, basal part flattened ventrally, distal part triangular or with a more rounded shape, often folded like pleated bellows (Figs. 126-128); (4) very long, shape poorly defined distally, as a wrinkled paper bag (Fig. 113); (5) not very long, with a rectangular shape in lateral view (Fig. 79). (Unordered)

State 0 occurs widely in the outgroup genera Polistes and Ropalidia, and is certainly primitive in these genera (see Richards, 1973; Kojima, 1982, 1984; Kojima and Kojima, 1988, Carpenter, 1996). Within Mischocyttarus, state 0 occurs invariably in the subgenera Clypeopolybia, Phi, and Kappa. State 1 is a putative synapomorphy of a small clade comprising M. cerberus, M. nomurae, and M. dimorphus. States 2 and 3 are more variable in form, and certainly had multiple origins in the outgroup genera and in various Mischocyttarus groups and species. State 4 occurs only in part of the surinamensis group and in the prominulus group. State 5 was found in $M$. smithii and M. acunai of the subgenus Mischocyttarus s. str.

53. Hairs on the digitus of the male genitalia: (0) digitus with long and conspicuous hairs quite distinct at the dissection microscope (Figs. 78-80, 162); (1) digitus bare or with very small whitish hairs visible only at high magnification (Figs. 81, 95-96, 110, 113, 117, 126-128).

This character is variable in Polistes, and was not mentioned by Carpenter (1996), so the genus is here treated as polymorphic. Species of the other outgroup genera presented the glabrous condition (state 1). Within Mischocyttarus, state 0 was observed in the nominotypic subgenus and in Clypeopolybia, other groups presenting state 1 .

54. Aedeagus of the male genitalia: (0) curved in lateral view; seen from above, with the distal portion narrow, then abruptly expanding to form a well differentiated apex whose lateral contour is more or less round (Figs. 76-77, 87-89, 99, 106-107, 112, 133); (1) curved in lateral view; seen from above, very wide from base to apex, the latter somewhat poorly differentiated with a broad round lateral contour (Figs. 74-75); (2) curved in lateral view; seen from above, with the distal portion wide, apex with a broad round lateral contour (Figs. 90-91, 98, 101-102, 119); (3) short and absolutely straight in lateral view; seen from above, apex with a broad round lateral contour (Figs. 104-105, 108-109); (4) curved in lateral view; seen from above, very wide from base to apex, distal portion extremely short and dorsally flattened, with parallel sides (Fig. 86); (5) curved in lateral view; seen from above, with the distal 

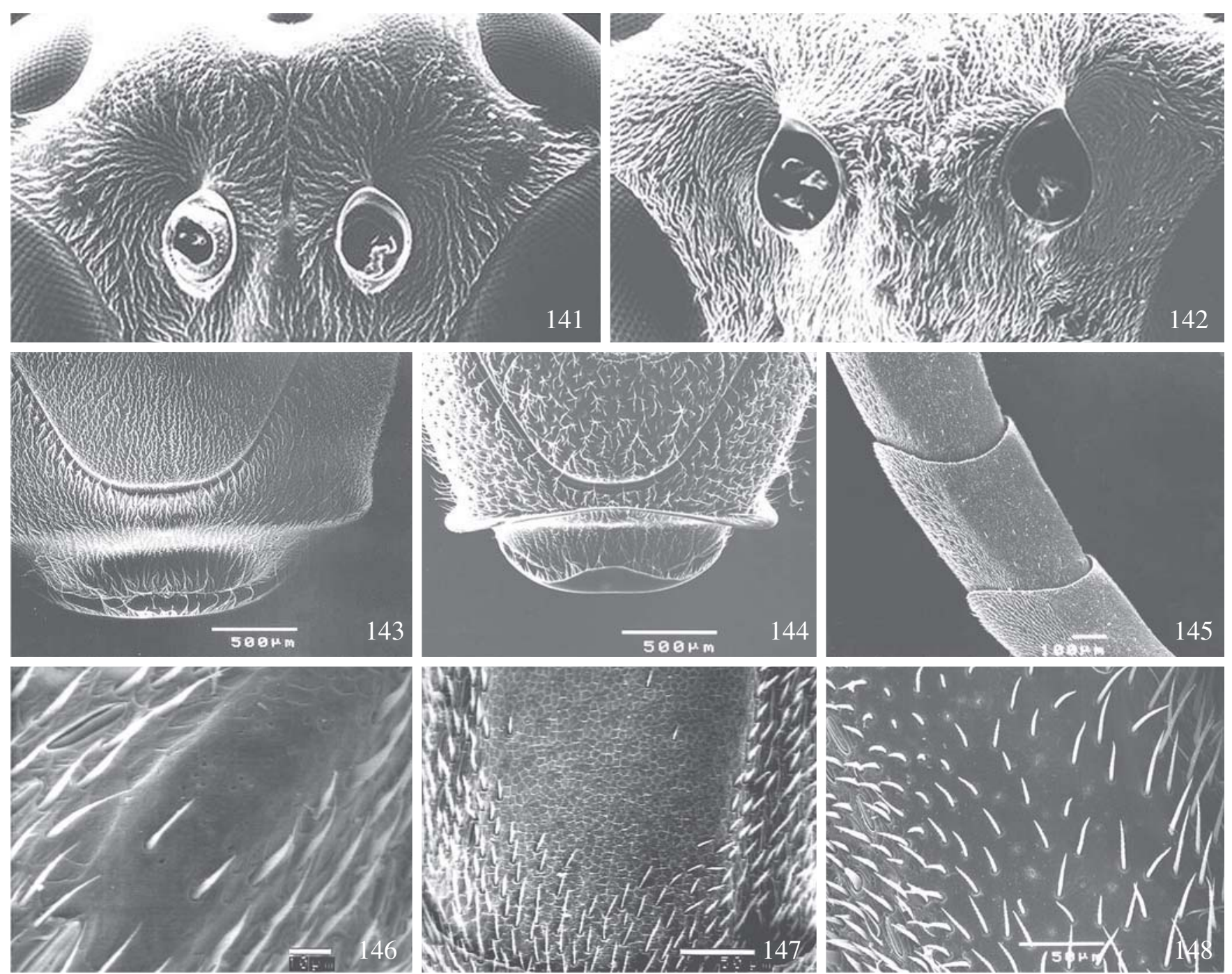

Figs. 141-148. (SEM). Frontal view of female head showing antennal sockets in 141, M. montei; 142, M. mexicanus; dorsal anterior view of pronotum in 143, M. immarginatus; 144, M. punctatus; general view of male antenna showing tyloids in 145, Polistes (Polistes) sp.; detail of male antennal tyloid in 146, Ropalidia flavobrunnea; 147, M. labiatus; 148, M. duckei.

portion narrow, then suddenly expanding to form a well differentiated apex whose lateral contour is distinctly angular (Figs. 120-121, 123-124, 129, 132, 134). (Unordered)

In the outgroup, forms corresponding to state 0 were observed in Polistes, Ropalidia, Belonogaster, and Polybioides. In Parapolybia indica, the aedeagus presented an extremely divergent shape, and Apoica and Agelaia also presented different forms of the aedeagus, certainly unrelated to the other states observed within Mischocyttarus. In this genus, state 0 occurs in Clypeopolybia, Scytokeraia, Phi, Megacanthopus, one undescribed species of Omega (male Brasil, PA, Serra Norte, Fofoca, 16/ix/1985, M. F. Torres; MPEG), and in part of Haplometrobius. State 1 occurs only in Mischocyttarus s. str. State 2 was observed in species of the heliconius group, in Kappa species and in M. artifex. State 3 occurs only in the iheringi group. State 4 is a putative synapomorphy of Monogynoecus (sensu Cooper, 1996a). State
5 was observed in the surinamensis and prominulus groups, and in most species of Omega (excepting the undescribed one mentioned above).

55. Ventral process of the aedeagus: $(\mathbf{0})$ a rounded lobe, not very large but quite visible from above (Figs. 76, 87, 112, 119); (1) a small narrow lobe, contorted inwards, with small teeth (Fig. 162); (2) a rounded lobe, contorted inwards, without teeth (Figs. 109, 163); (3) a very long narrow lobe (Fig. 86); (4) a large angular lobe (Figs. 99, 101-102, 107, 164). (Unordered)

States 1, 2, 3, and 4 are putative synapomorphies respectively of Mischocyttarus s. str., the iheringi group, Monogynoecus, and the artifex group.

56. Basal area of the aedeagus: (0) completely sclerotized, continuous with the paramere basal processes; (1) sclerotized portion of the base of the aedeagus a linear elongate lobe 

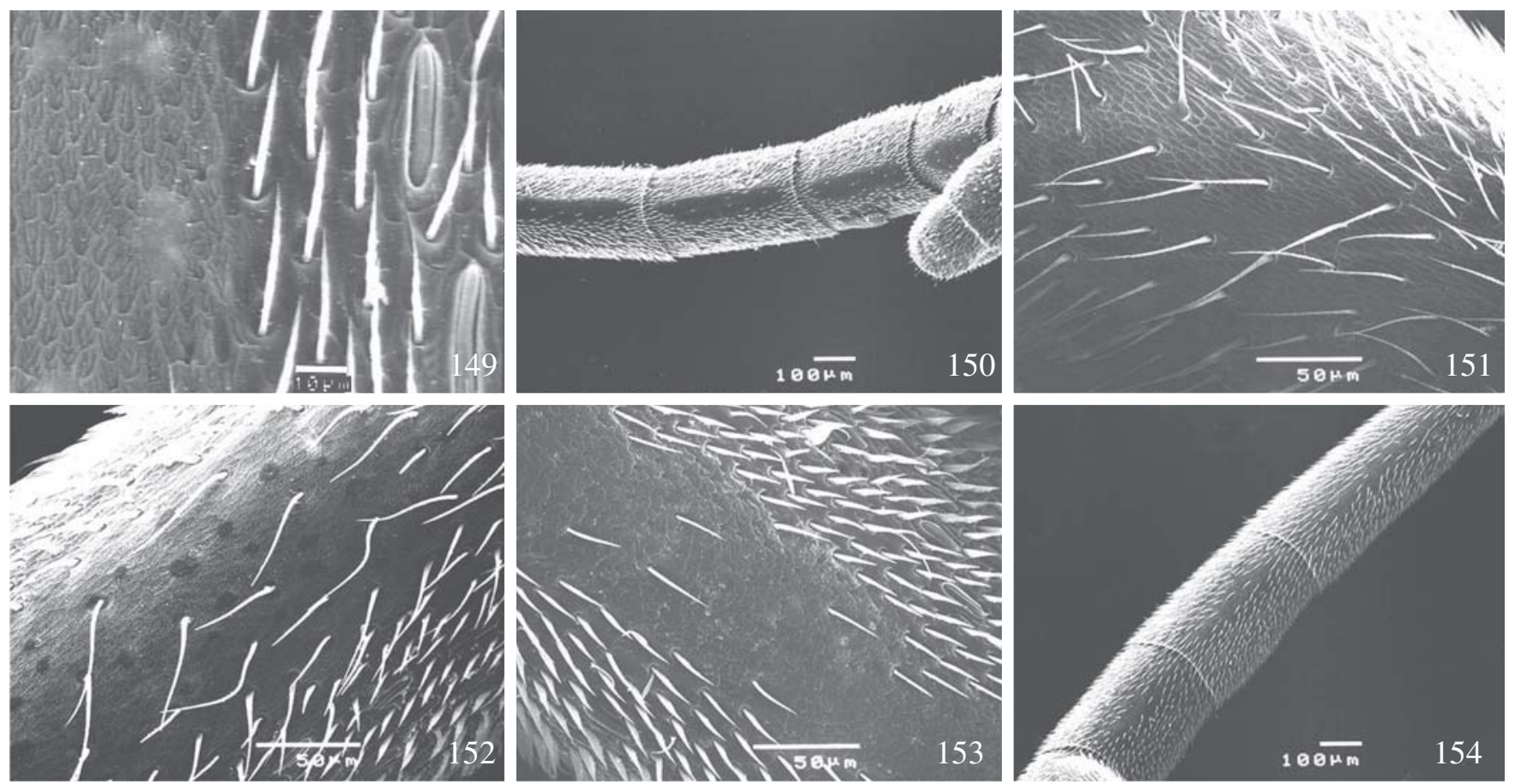

Figs. 149-154. (SEM). Detail of male antennal tyloid in 149, M. mastigophorus; 151, M. synoecus; 152, M. ornatus; 153, Mischocyttarus sp. gr. heliconius (MPEG); general view of male antenna showing tyloids in 150, M. montei; 154, Mischocyttarus sp. gr. surinamensis (UCDC).

developed anteriorly up to the paramere basal processes (Figs. 120-121, 123-124, 129, 133-134); (2) sclerotized portion of the base of the aedeagus with a round or angular shape, not much developed anteriorly, not reaching the paramere basal processes. (Ordered 0-1-2)

State 0 was found in the outgroup genera only. State 1 was observed in most species of Omega (excepting an undescribed one of the punctatus group; male; Bolivia, La Paz, Caranavi, 600m, 16/v/1979, M. Cooper; BMNH), and in the surinamensis and prominulus groups. State 2 was found in all other Mischocyttarus groups.

57. Long hairs on the external surface of distal part the paramere of the male genitalia: (0) absent (Figs. 82-85, 92-94, 100, 103, 111, 114-115, 116, 118); (1) present (Fig. 97).

State 1 is a putative synapomorphy of Kappa sensu Richards (1978).

58. Hairs on the parameral spine of the male genitalia: $(\mathbf{0})$ long and numerous hairs, distributed over an extensive zone of the parameral spine (Figs. 82-85, 92, 94); (1) long but less numerous hairs (Fig. 114); (2) a few very long hairs restricted to the apical part of the parameral spine (Figs. 97, 122, 125); (3) a few short, but reasonably conspicuous hairs restricted to the apical part of the parameral spine (Figs. 93, 111, 118); (4) a few extremely short inconspicuous hairs, parameral spine nearly glabrous (Figs. 100, 103, 115-116, 130-131). (Unordered)

Another character that is variable in the outgroup. Polistes spp. and Parapolybia indica presented state 0 , while in most of the other outgroup genera the hairs on the parameral spine are strongly reduced in number and size (state 4). In Ropalidia, the examined species $R$. flavobrunnea and $R$. fasciata present state 4, but several drawings in Charnley (1973) show that state 0 also occurs in the genus. The Ropalidiini were thus scored as polymorphic. Within Mischocyttarus, a condition similar to the state in Polistes was observed in Mischocyttarus s. str., Clypeopolybia, Scytokeraia and Phi. In M. acunai (Fig. 131), the hairs on the parameral spine are less developed than in other species of Mischocyttarus s. str., this being an autapomorphy of the species. In the other subgenera, the hairs are always less developed than the condition in state 0 , this being often associated with more or less differentiated shapes of the parameral spine. State 1 is a putative synapomorphy of a group constituted by $M$. cerberus, M. nomurae, $M$. dimorphus, and $M$. peruanus. State 2 occurs typically in Kappa, but a quite similar condition was observed in the surinamensis and prominulus groups of Haplometrobius. State 3 was found in species of the ihering group of Haplometrobius, in Monogynoecus and Megacanthopus. State 4 , the nearly glabrous condition, was observed in the heliconius, mendax, and artifex groups, and in Omega.

\section{MATURE LARVA}

59. First abdominal segment of the mature larva: (0) without any ventral processes; (1) with one ventral median process; (2) with two ventral processes; (3) with three ventral processes. (Unordered)

Occurrence of ventral processes on the first abdominal segment of the larva is only known in Mischocyttarus. For this very reason, it is impossible to infer which of states $1-3$ is 

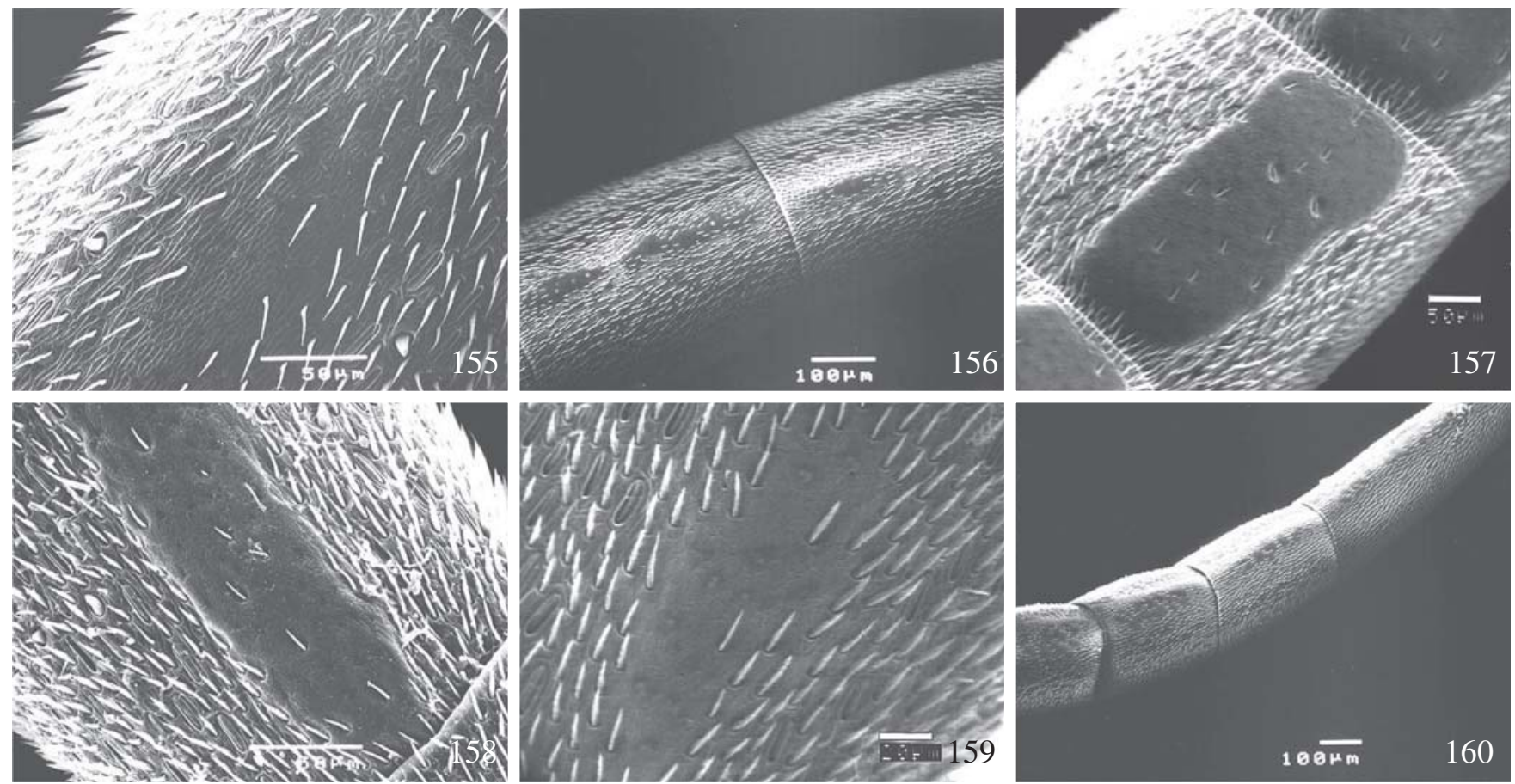

Figs. 155-160. (SEM). Detail of male antennal tyloid in 155, Mischocyttarus sp. gr. surinamensis (UCDC); 157, M. imitator; 158, M. extinctus; 159, M. itatiayaensis; general view of male antenna showing tyloids in 156, M. immarginatus; 160 , M. cassununga.

plesiomorphic in the genus using outgroup argumentation. State 2 has the widest distribution, in most of the subgenera, but occurring in somewhat diverse forms. State 1 occurs only in the subgenus Kappa. State 3 is only known from two species of Clypeopolybia (M.flavicans and M. carbonarius). Recently, Kojima (1998) described the larva of $M$. carbonarius tibialis Richards reporting the occurrence of only two ventral processes, which is incongruent with the information available for typical M. carbonarius. But Richards (1978) indeed noticed the existence of morphological differences between his new subspecies and $M$. carbonarius, apparently deciding to give subspecific status to the former by virtue of the small number of specimens available from a single locality. Altough types of tibialis were not available for this study, two females from Costa Rica (INBC) agree very well with Richards' description of tibialis, and a male specimen collected by Ducke in Brazil, Amazonas state (MPEG) is probably the same species. The differences noticed by Richards in respect to body size and shape of the pronotal carina are confirmed, and clearly indicate (jointly with information from Kojima, 1998) that tibialis is a distinct valid species.

\section{NEST CHARACTERS}

60. Nest comb: (0) irregular polygonal or suboval cluster; (1) circular cluster with central attachement to peduncle; (2) vertically elongated cluster several rows wide; (3) vertically elongated 1-3 rows-wide comb with cell displacement; (4) 1-3 interconnected (nonadjacent) rows parallel to substrate; (5) polygonal cluster facing substrate, bottom with moss particles. (Unordered)
State 1 is a putative synapomorphy of Mischocyttarus s. str. State 2 occurs in several species of Phi like M. mexicanus, $M$. cassununga, M. crypticus, and M. cryptobius, and also of other subgenera, like $M$. interjectus (artifex group of Haplometrobius sensu Richards, 1978), and M. subornatus (Scytokeraia) (see Zikán, 1949, figs. 365, 370, 379, 385, 386, 394, 401; Cooper, 1997a). It is similar to state 3, but does not have the extreme cell displacement observed typically in nests of $M$. punctatus or most species of the artifex group (see Cooper, 1998b; Ducke, 1914; Wenzel, 1991). State 4 is only found within the group of $M$. iheringi, in species like $M$. weyrauchi, $M$. naumanni, and $M$. cooperi. The nest may be constituted of a single (see Zikán, 1949; Fig. 369) or multiple combs, at times resulting in rather strange forms (Cooper, 1998a; figs. 1-2). State 5 is also typical of some species of the iheringi group.

61. Comb external walls: (0) convex; (1) flattened.

State 1 occurs typically in the subgenus Megacanthopus.

62. Nest pedicel: (0) short and wide; (1) long and thin, thread-like.

State 1 is typically seen in Mischocyttarus s. str., but a similar condition was observed in several nests of $M$. (Clypeopolybia) carbonarius.

Phylogenetic Results

Unweighted-analysis

Searches of the uniformly weighted data set using the program NONA 2.0 yielded 32 trees of length $339, \mathrm{CI}=36$ 

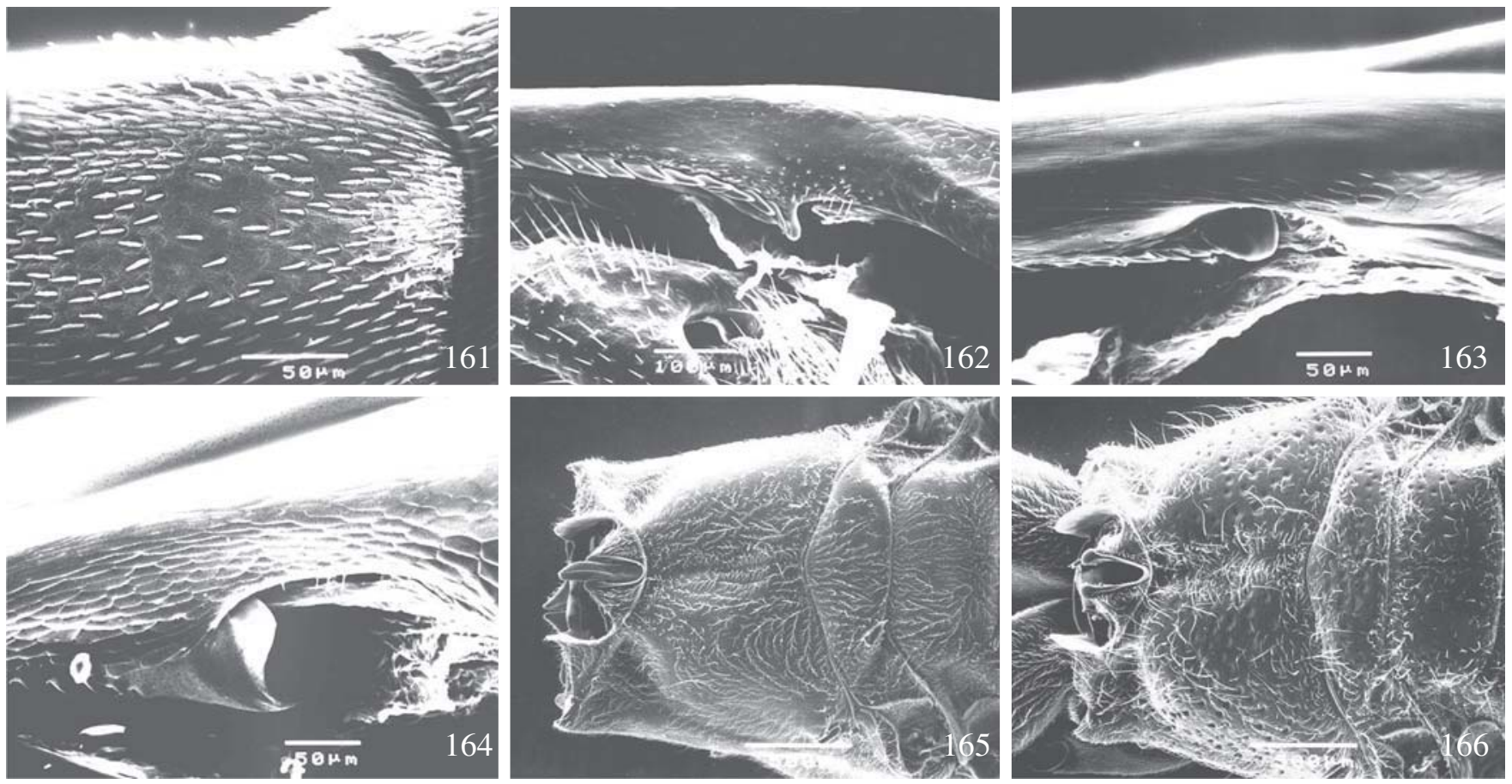

Figs. 161-166. (SEM). Detail of male antennal tyloid in 161, M. cassununga; lateral aspect of male aedeagus and digitus in 162, M. drewseni; lateral detail of male aedeagus showing ventral process in 163, M. iheringi; 164, M. synoecus; dorsal view of propodeum in 165, Mischocyttarus sp. gr. alboniger (INPA); 166, M. punctatus.

(ensemble consistency index), RI= 81 (ensemble retention index). TNT 1.0 found the same trees. The strict consensus is presented in figure 173 along with clade support values (absolute and relative Bremer supports).

The tree in figure 173 is in reasonable agreement with the current internal classification of Mischocyttarus (Cooper, 1997a; Richards, 1978). The basal split involving Mischocyttarus s. str. and Clypeopolybia species at one side, and a large component (mastigophorus-iheringi) formed by remaining groups of the genus is somewhat reminiscent of the earlier classification by Ducke (1904) who created the genus Megacanthopus for all "Polybia" species with asymmetric tarsal lobes that were not strictly similar to M. labiatus. This component is supported in all trees by transformations in four characters $(1: 2>0,11: 0>1,25: 0>1$, and 46: $0>2)$, the most reliable being the unique loss of a basal sulcus on fore and mid femora (character 25).

Six of the nine recognized subgenera appear in the consensus tree as monophyletic groups, with the notable exceptions of Clypeopolybia, Phi and Haplometrobius. As to the first subgenus, four topological solutions exist among the 32 trees found, two of them presenting the group as paraphyletic with respect to Mischocyttarus s. str. The latter configurations show a closer relationship between the larger species of Clypeopolybia (M.flavicans and M. carbonarius) and the species of Mischocyttarus s. str., being supported by shared similarities either in the shape of the pronotum (character 21: $0>1$ ) and the propodeal median furrow (character $34: 2>1$ ), or additionally in the shape of nest pedicel (between
M. carbonarius and Mischocyttarus s. str.; character 62: 0>1). Alternatively in the other trees found, Clypeopolybia appears as a monophyletic group supported by the flattened anterior femur (character 26: $0>1$ ), and the deep clypeal lateral indentations (character 9: 0>1).

Regarding subgenus $P h i$, all trees showed it as paraphyletic with respect to Kappa (M. extinctus is sister to the subgenus Kappa). While such an improbable relation is only supported by a homoplastic transformation in the clypeal apex (character 8: $0>4$; narrowly truncate to narrowly round), the remaining Phi component (consimilis-flavitarsis) is supported by the unique reduction of the male antennal tyloids (character 44: $0>1$ ) and the homoplastic reduction of the lateral margin of the distal portion of the first metasomal sternum (Character 40: $1>2)$.

Problems with the subgenus Haplometrobius seem far more extensive and complicated because keeping such a widely inclusive group in the consensus tree (mendax-nigropygialis) would necessarily embrace representatives of five other subgenera.

Weighted-analyses

Under implied weights (option $\mathrm{k}=1$ ) with program PeeWee 3.0, 464 trees of fit 294.9 were found. These trees are 17 to 22 steps longer (length: 356 - 361) than those found under equal weights. The strict consensus is presented in figure 174 along with absolute and relative Bremer supports estimated with Pee-Wee. Appendix 2 shows a list of character changes supporting each node of this consensus tree, but only those 

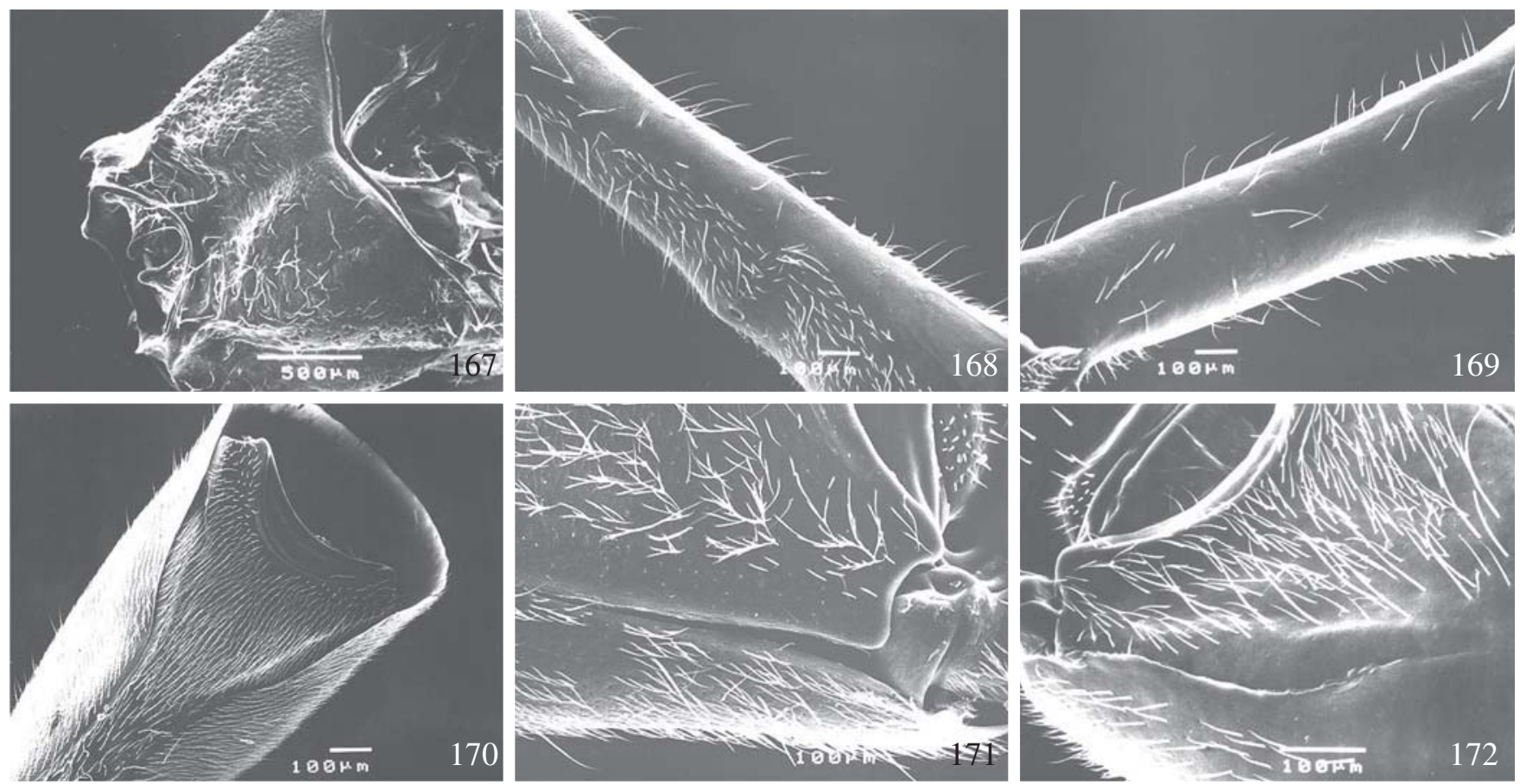

Figs. 167-172. (SEM). Dorsal view of propodeum in 167, M. injucundus; ventral view of petiolar first metasomal segment in 168, Mischocyttarus sp. gr. alboniger (INPA); 169, M. punctatus; ventral distal view of first metasomal segment in 170, M. montei; same part, lateral detail in 171, M. mexicanus; 172 , M. punctatus.

(unambiguous) changes appearing in "all trees". The consensus shows still better agreement with traditional classification, all subgenera now appearing as monophyletic except Haplometrobius. The basal split between Mischocyttarus s. str. + Clypeopolybia and a large component formed by remaining groups is again apparent, the latter being supported by the unique loss of a basal sulcus on fore and mid femora (character 25: $0>1$ ), and the homoplastic loss of the occipital carina (character 1:2>3).

Major differences in respect to the consensus tree obtained under equal weights (paraphyly of $P h i$ aside) are the positions of subgenera Monogynoecus and Kappa, and of the speciesgroups of M. mendax and M. heliconius. In the first analysis, a putative sister-group relation between Monogynoecus and a component formed by species of Haplometrobius, Megacanthopus and Omega (mirificus-ornatus; Fig. 173) seems to be problematic. Some plesiomorphic features occur in Monogynoecus like the fairly circular antennal sockets in female (character 11) and characters of the male mandibula (characters 48, 49, and 50; state 0 in all these cases) suggesting a more basal position for the group. Under implied weights $(\mathrm{k}=1)$, the shape of antennal sockets is indeed the character supporting the relationship between Scytokeraia and a large component formed by several subgenera (Fig. 174) to the exclusion of Monogynoecus (and of Mischocyttarus s. str. and Clypeopolybia).

With respect to the subgenus Kappa, implied weights $(\mathrm{k}=1)$ render it member of a small group also comprising elements of the M. heliconius group (Fig. 174), this group itself being part of a larger clade including the M. mendax group and other elements of subgenera Haplometrobius, Megacanthopus and Omega. These relationships are very different from those obtained under equal weights (in which Kappa appears as closely related to part of $P h i$ ), and must be due mainly to the reduction of the fourth tooth of male mandible in Kappa (character 50, state 1 ).

There are four possible configurations in trees for the three terminals representing $M$. chanchamayoensis and other species of the M. heliconius group, two of these arrangements being paraphyletic relative to Kappa. Support for this component comes from a set of six characters $(1: 3>0,8: 3>4$, 10: $0>1,12: 0>1,15: 0>1$, and 54: $0>3)$, but only characters 1 (occipital carina present) and 8 (clypeal apex narrowly rounded) support the group in all trees. Interestingly, Richards (1945) considered M. heliconius as part of Kappa (then with a much wider concept) before transferring the species-group to subgenus Clypeopolybia (Richards, 1978; see also Silveira, 1998). As to the terminal representing the group of M. mendax, under implied weights $(\mathrm{k}=1)$ it appears in trees as sister-group either of the clade formed by species of the M. heliconius group and Kappa, or of the whole large component involving Kappa, parts of Haplometrobius, Megacanthopus and Omega.

The consensus tree of the weighted analysis $(\mathrm{k}=1$; Fig. 174) shows most species-groups of Haplometrobius (cerberus, surinamensis, prominulus, artifex, and iheringi groups) as parts of a component which also includes the subgenera Megacanthopus and Omega, and whose prominent supporting character in all trees is the absence of the pronotal fovea 
(character 23: 0>1). In some trees, characters 45: 0>1 (erect hairs of male antenna) and 58: 4>3 (hairs of male paramere spine) also support the group. A rather similar group was obtained in the analysis under equal weights, except for the inclusion of $M$. chanchamayoensis and the other species of the $M$. heliconius group as a small clade sister to the $M$. ihering group (Fig. 173). This latter pattern of relationships is suggestive of Richards's (1978) concept of the M. iheringi group, i.e. including also $M$. chanchamayoensis and $M$. undulatus sensu Richards (1945). However, support for such a group is meager, based on particular transitions in the homoplastic characters 1: $2>1$ (occipital region just compressed dorsally and laterally) and 17: 2>1 (anterior marginf of proepisternum low, not reflexed, lateral portion shaped as a wide collar).

In the weighted analysis $(\mathrm{k}=1)$, the large clade supported by absence of the pronotal fovea appears in four different topologies according to the different arrangements of its major internal elements (Fig. 175). In all these topologies, the speciesgroups of M. surinamensis and M.prominulus appear as nested paraphyletic assemblages, with one element of the prominulus goup being more closely related to subgenus Omega. Species of the group of $M$.artifex form a monophyletic group in some topologies (Figs. 175a, b, c), but a paraphyletic one in some trees in which a major part of it (artifex-sylvestris) appears as sister of the iheringi group, to the exclusion of M. mirificus (and related species M. ypiranguensis, M. schadei and $M$. thrypticus) (Figs. 175d). The species-groups of $M$. iheringi (in the sense of present work) and $M$. cerberus are monophyletic in all trees (see also Silveira, 2004).

Analysis with different values of the constant " $k$ " of concavity

Using alternative (less stringent) values for the constant of concavity " $k$ " in the program Pee-Wee resulted in different topologies, but some important congruence is apparent. Consensus trees obtained with values of " $k$ " equal to 2 and 3 (the latter being the default value in Pee-Wee) are showed in figures 176 and 177 respectively (with absolute and relative Bremer supports). As in the analysis with " $k$ " equal to 1 , all subgenera are again monophyletic except Haplometrobius. Topological relations in the basal part of the trees are also similar to previous weighted analysis in that Mischocyttarus s. str. plus Clypeoplolybia are sister to a large component formed by remaining subgenera, and that Monogynoecus and Scytokeraia occupy basal (and consecutive) positions in this large component. Furthermore, all weighted analyses found a clade composed of "afoveate" species-groups of Haplometrobius and the subgenera Omega and Megacanthopus. Differences in internal relationships within this clade mainly refer to monophyly/paraphyly of the speciesgroup of M. artifex, and differing positions of Megacanthopus. However, using larger values of " $k$ " resulted in hypotheses of a sistergroup relationship between the subgenera Kappa and Phi (Figs. 176, 177, 178, 179 and 180), similar to the configuration verified under equal weights. In some trees obtained with " $k$ " equal to 4 and in all trees obtained with " $k$ " larger than this

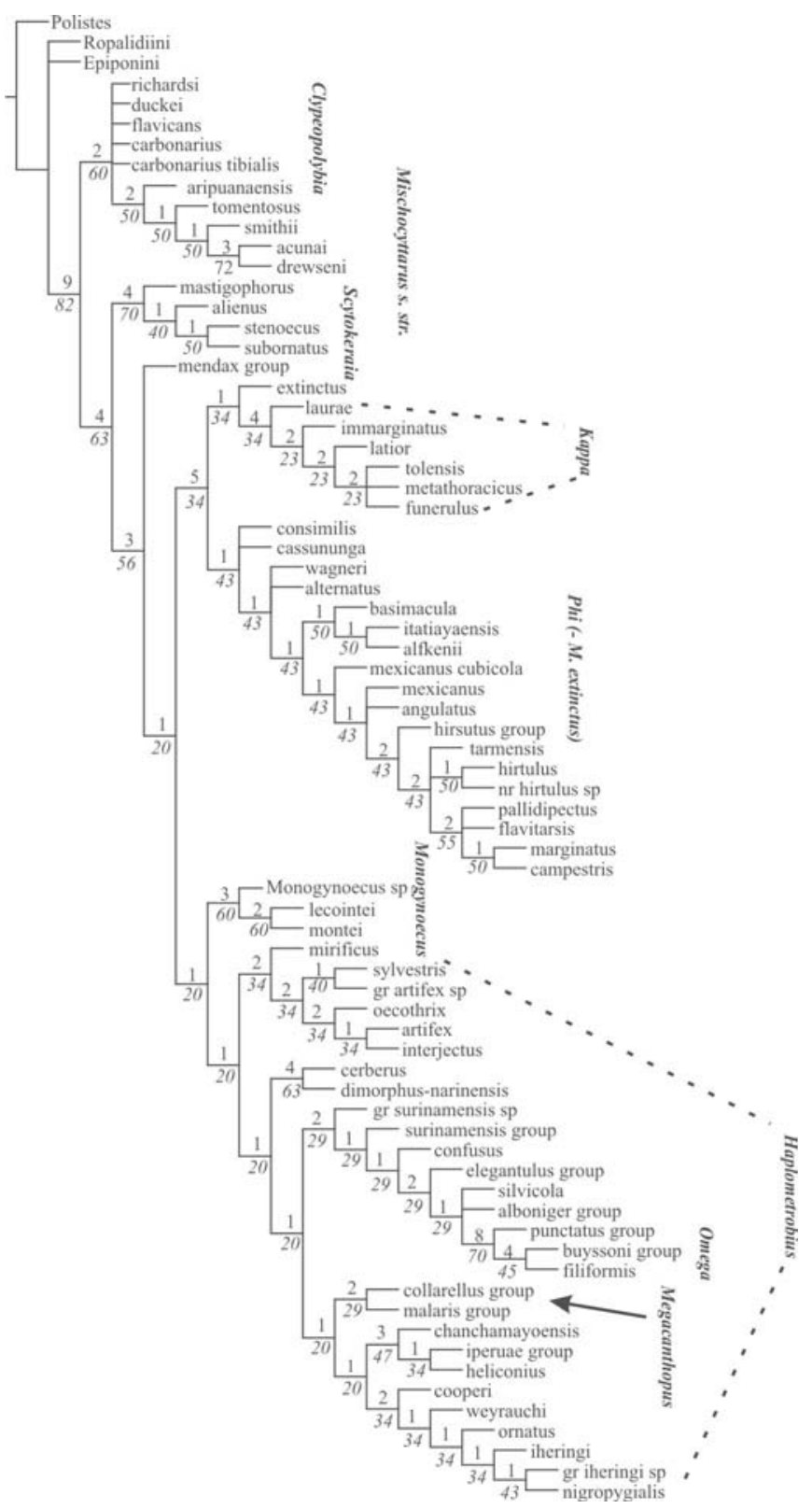

Fig. 173. Strict consensus of 32 trees ( $L=339$; CI 36; RI 81) found under equal weights with NONA 2.0 for Mischocyttarus major species groups. Absolute (above) and relative (below) Bremer supports are presented for ingroup branches, except when the value exceeded the upper limit considered (i.e. $>100 \%$ ).

value (5 and 6), the relative positions of Monogynoecus and Scytokeraia are changed in the basal sector of trees.

Analysis with TNT 1.0 under implied weights produced a same set of just 3 trees irrespective of the value of the concavity function " $k$ ". The strict consensus of these trees is presented in figure 181. It is very similar to consensus trees obtained with Pee-Wee with larger values of "k" (equal to 5 or 6 ; compare with figures 179 and 180), except that with Pee-Wee Megacanthopus is never placed "within" the M. surinamensis group. According to documentation of TNT (Goloboff et al, 
2005; file TNT.htm), the fit for discrete additive characters is calculated by decomposing the character into binary variables, and it is possible that the fits calculated by TNT were different from those of Pee-Wee. Whether such recoding may produce a "more meaningful evaluation of the relative weights" of characters (see also Carpenter, 1988b), actual support for the relationship between Megacanthopus and some elements of the group of $M$. surinamensis, and of these with the group of M. prominulus and Omega (shape of occipital region: 3>2; anterior margin of pronotum with the lamella wide and strongly reflexed: 1>2) should hardly be considered robust evidence. Megacanthopus does not have some distinctive apomorphies of the male genitalia that were found uniquely in the $M$. surinamensis and $M$. prominulus groups and most species of Omega. Overall evidence thus indicates that the particular relationship inferred with TNT is probably incorrect.

\section{DISCUSSION}

Conclusions of this work about phylogeny within Mischocyttarus, and a new classification for the genus are mainly founded on weighted analysis. Goloboff $(1993 a, 1997)$ presents convincing justification for using implied weights in cladistic analysis. Quoting Farris (1983) and Carpenter (1988b), he argues that inferring weights a posteriori based on the homoplasy that characters show in examined trees makes use of "all the evidence" contained in a given set of characters. Differences on cladistic reliability of characters revealed during the analysis are thus used to choose the hypotheses reflecting the strongest evidence. Goloboff's method has since been widely used, and some authors have preferred it over equal weights (Melo, 1999; Fontal-Cazalla et al, 2002).

In spite of the admirable work of earlier authors like Ducke, Zikán and Richards, we still had no good ideas on phylogenetic relationships within Mischocyttarus, except for the general and untested hypotheses implied by the classification of subgenera and species-groups, constructed with traditional taxonomic methods. The present work brings a wealth of new information to the subject, but is still limited in some important ways. The number of characters is relatively small relative to the large number of terminals used. In addition, crucial information on morphology of males, larvae and nests were lacking for a number of species, many of them only known from one or a few female specimens. So we are centainly still far from a satisfactory knowledge of the species phylogeny of the genus, stable and detailed enough to give support to the rich spectrum of opportunities on comparative research of behavior.

\section{Monophyly of Mischocyttarus}

The outstanding character of the genus traditionally used in keys is the asymmetry of lobes of more distal tarsomeres of mid and hind legs. Importance of this character (unique in Polistinae) was already evident in the key presented by Ducke (1904:.320), couplet 2 leading to both Mischocyttarus s. str.

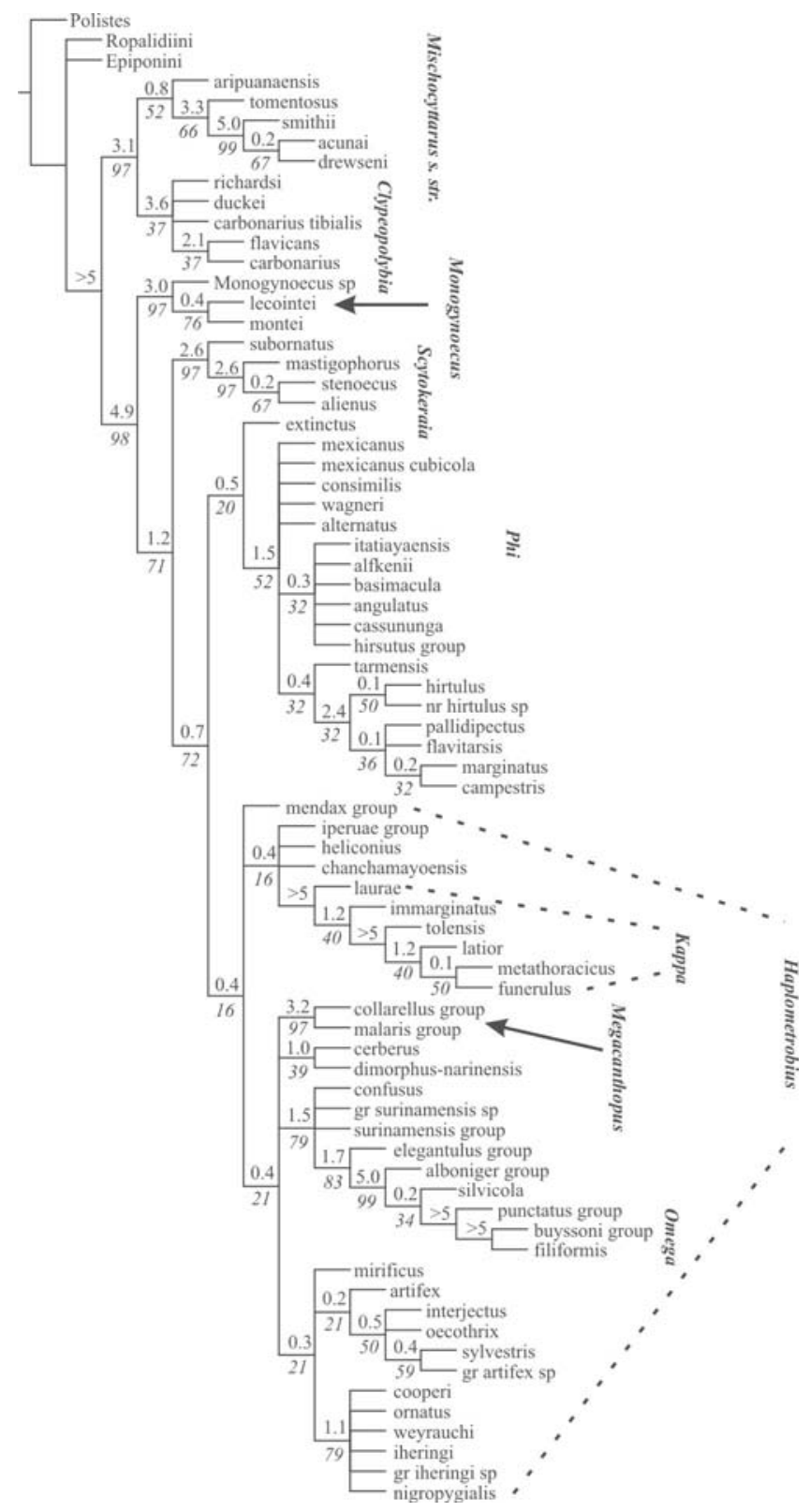

Fig. 174. Strict consensus of 464 trees $(F i t=294.9)$ found under implied weights $(\mathrm{k}=1)$ with Pee-Wee 3.0 for Mischocyttarus major species groups. Absolute (above) and relative (below) Bremer supports are presented for ingroup branches, except when the value exceeded the upper limit considered (i.e. $>100 \%$ ).

and the new genus Megacanthopus. However, in the paper that established the modern concept of the genus, Ducke (1913) did not discuss details about characters, just mentioned that his genera Megacanthopus and Monacanthocnemis, by morphological and ethological criteria should belong in fact to Mischocyttarus de Saussure. Quite interestingly, asymmetry of tarsal lobes received no mention in the description of Mischocyttarus s. str. presented by de Saussure (1853). A larval feature referring to the presence of one or more processes on the first abdominal segment has also been recognized as a character typical of the genus (Richards, 1978). In the present 

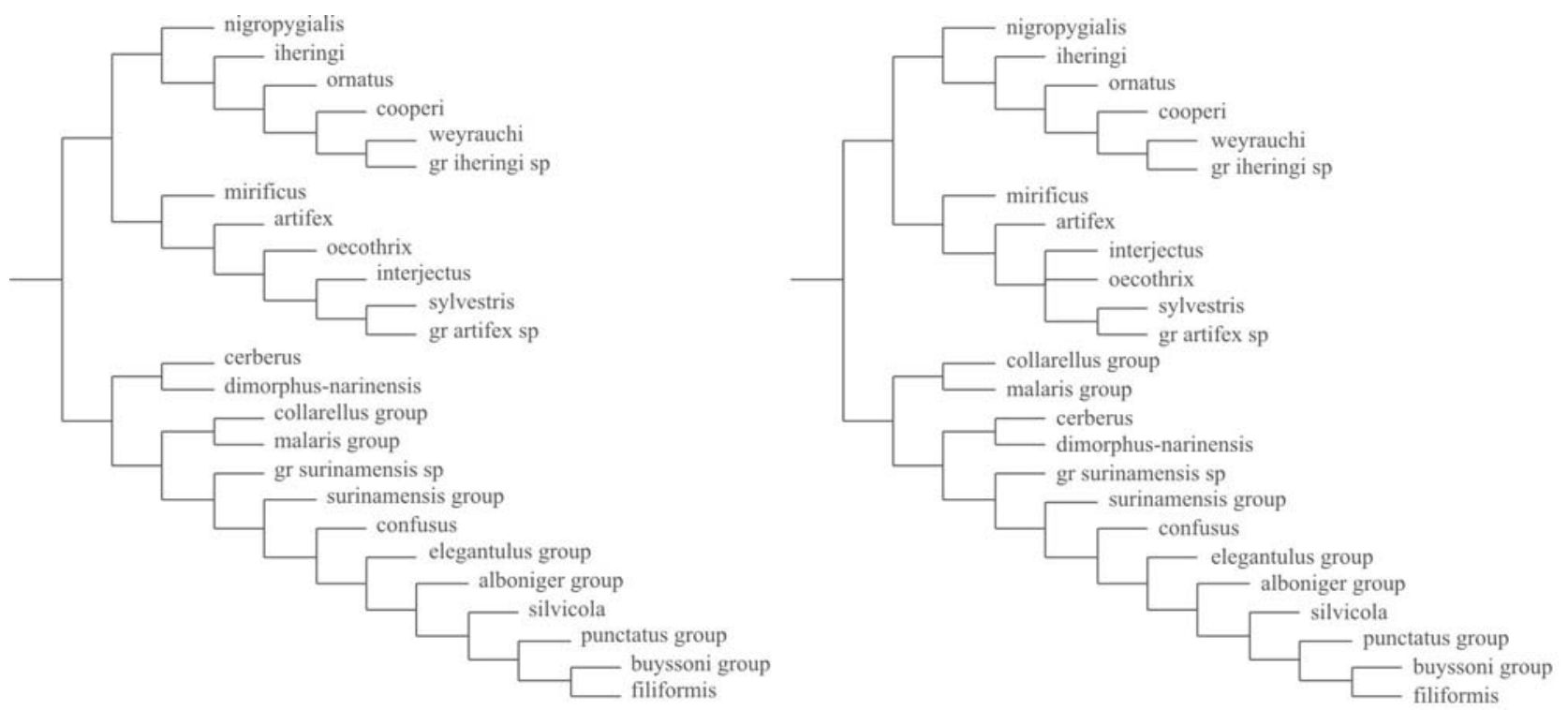

A
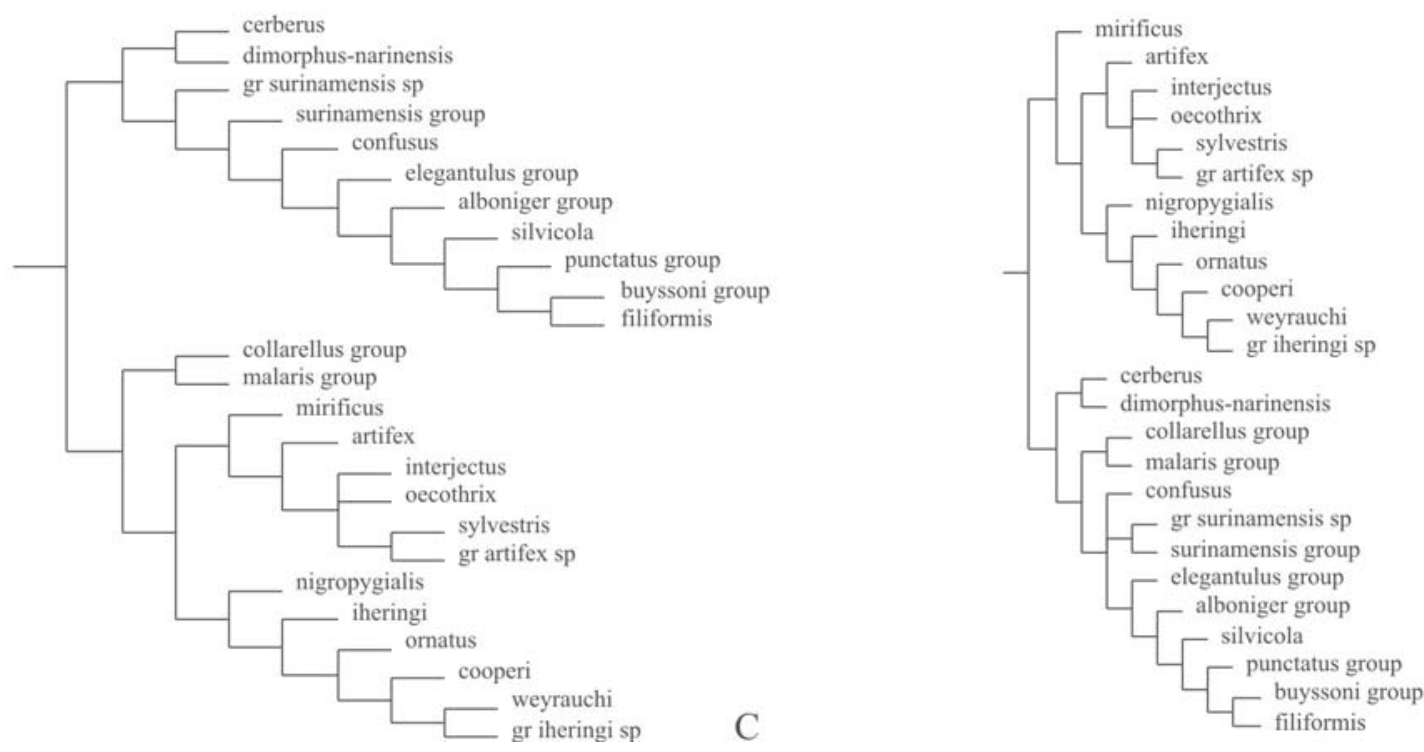

Fig. 175. The four types of topologies found under implied weights $(\mathrm{k}=1)$ with Pee-Wee 3.0 for "afoveate" Mischocyttarus species.

study, character state 2 (larva with two ventral processes) was inferred as the primitive condition in the genus in all the analyses. Weigthed and unweighted analyses resulted in nearly identical sets of characters supporting monophyly of Mischocyttarus. Besides the two mentioned above, newly discovered synapomorphies of the genus (unique in Polistinae) are the posterior margin of the pronotum laterally nearly straight below the pronotal tubercle, with the ventral angle being in a fairly anterior position (character 27 , state 1 ; Figs. 53, 54, 56), and the sclerotized basal portion of the aedeagus less extensive, with a round or angular shape, not reaching the paramere basal processes (character 56, state 2; Figs. 74-77, 86-91, 98-99, 101-102, 104-109,112, 119, 132).

Relationships of Mischocyttarini with other closely related polistine tribes were not the main focus of this work, and the characters studied indeed shed no new light on the subject.

\section{Monophyly of subgenera}

Seven of the nine currently recognized subgenera resulted as monophyletic taxa in all analyses: Mischocyttarus s. str., Clypeopolybia, Monogynoecus, Scytokeraia, Kappa, Megacanthopus and Omega. Phi showed up as a paraphyletic group in the unweighted analysis, but as a monophyletic one in all the weighted analyses. Haplometrobius proved to be an unnatural catch-all taxon for rather heterogeneous speciesgroups left behind after formal recognition by Richards of better defined less inclusive subgenera (i.e. Megacanthopus sensu Richards, 1978, and Omega). This study found no evidence in favor of its monophyly. A clade including all species of Haplometrobius would also have to comprise species of 
Kappa, Phi, Omega and Megacanthopus, or at least Omega and Megacanthopus.

Relationships between subgenera and species-groups

The basal dichotomy in the phylogeny of Mischocyttarus appeared in all analyses (figs 173, 174, 176, 177, 178, 179, 180, 181). There seems to be no doubt on the existence of two major clades, one formed by Mischocyttarus s. str. and Clypeopolybia, and the other by all remaining species-groups. Weighted analyses showed that Monogynoecus and Scytokeraia occupy basal and (in most analyses) consecutive positions in this second component (fig 174, 176, 177, 178, 179, 180). As already stated, a sister-group relationship between Monogynoecus and a large component formed by species of Haplometrobius, Megacanthopus and Omega as obtained in unweighted analysis (Fig. 173) is very improbable. The circular antennal sockets and features of the male mandibule in Monogynoecus suggest a more basal position. Weighted analyses with the constant of concavity " $\mathrm{k}$ " equal or larger than 4 caused inversion of relative positions of Monogynoecus and Scytokeraia (Figs. 179 and 180). This is mainly due to weighting conditions favoring characters 17 (anterior margin of the proepisternum) and 24 (inner margin of the anterior coxa), of which Scytokeraia has the ancestral state. Other limited evidence coming from a larval feature not used in this study may favor the opposite situation, i.e. with Monogynoecus splitting off first. In this subgenus, mature larvae normally possess a dorsal process on abdominal segment 10 (dorsal knob of Richards, 1978), the same structure being observed in Polistes, in at least one species of Apoica, in the subgenus Clypeopolybia and in some species of Mischocyttarus s. str. (see Dias-Filho, 1975; Kojima, 1998; Reid, 1942; Richards, 1945, 1978). Such a structure has not been reported in other groups of Mischocyttarus, and its absence might well constitute an additional synapomorphy of a clade composed by Scytokeraia and remaining subgenera. However, it seems to be too much variable, possibly even between larvae of one same colony. Furthermore, larval forms of many species of Phi, especially in Richards's group of M. flavitarsis remain unknown.

Solving the problem of relationships of Kappa seems to be decisive to reconstructing phylogeny in Mischocyttarus. This subgenus appeared as more closely related to Phi in most of the weighted analyses, or to part of Phi in the unweighted analysis (figs 173, 176, 177, 178, 179, 180). Sets of character transformations supporting such hypotheses are large and similar among analyses, involving: character 5: $0>1$ (hairs on posterior ventral part of the gena longer and more numerous; weighted only); character 12: $0>1$ (ocelli moderately separated, positioned as the vertices of an equilateral triangle; unweighted only), character 20: $1>3$ (central portion of the pronotal carina completely reduced at center); character 32: 2 $>1$ (hind tarsal claws asymmetric, the internal one larger and presenting the apex sharp or narrowly pointed; weighted only); character 33: $1>2$ (propodeum with lateral surface inflated and with lateral posterior concavity); character 34: $2>3$

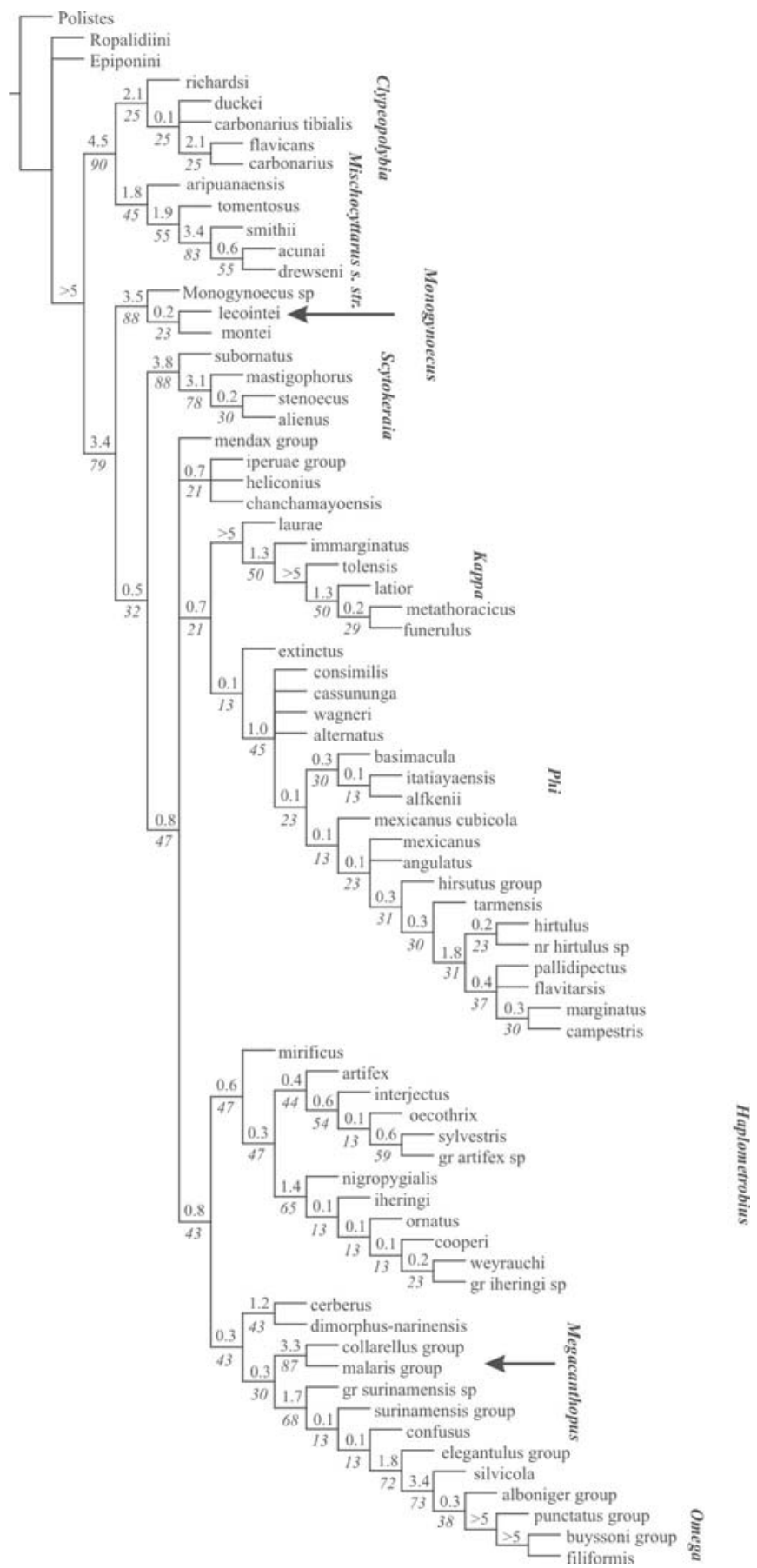

Fig. 176. Strict consensus of 6 trees $($ Fit= 351.2) found under implied weights $(\mathrm{k}=2)$ with Pee-Wee 3.0 for Mischocyttarus major species groups. Absolute (above) and relative (below) Bremer supports are presented for ingroup branches, except when the value exceeded the upper limit considered (i.e. $>100 \%$ ).

(propodeal median furrow wide and triangular); character 35: 1 $>2$ (metanotum triangular and moderately convex); character 39: $0>2$ (first metasomal segment with a shallow profile, ventrally with a poorly developed angle at a point positioned posteriorly to the spiracle); character 40: $0>1$ (lateral margin of first metasomal sternum reduced for the most part, sharp 
only on its distal extremity character; unweighted only) 46: 2 $>1$ (antenna strongly shortened, with a hook-like apex, apical articles cylindrical, distinctly narrower than basal ones; weighted only); character 52: $1>0$ (digitus of the male genitalia very long, distally with a finger-like shape).

However long the above list of characters, the only transformation that is unique in all the trees is in character 34 referring to shape of the propodeal median furrow. The list reflects the great general similarity between species of Kappa and $P h i$. Suffice to say that all these species were considered members of a single subgenus by Richards (1945). Perhaps the most apparent of these similarities refers to the reduced pronotal carina (apomorphic and rather restricted in the genus Mischocyttarus). A hidden but not less important character is the elongated digitus of male genitalia (plesiomorphic in the genus). However, the male mandible in Kappa species has only three apical teeth, a derived feature shared with all species of Haplometrobius, Megacanthopus and Omega. This is the main reason for the different relations of Kappa obtained in weighted analysis with " $k$ " equal to 1 , where it appears as part of a clade including also species of the M. heliconius group. In respect of this character, it is interesting to note that in most analyses where Kappa and Phi result closely related, the primitive state "with four apical teeth" appears in Phi as a reversed synapomorphic character of this subgenus. The only exception to this particular instance of character optimization was in the analysis under equal weigths, where a radically different position of Monogynoecus makes the derived state in Kappa being treated as independent of that in other subgenera wich also present a male mandible "with three teeth".

While the hypothesis of a clade formed by the "afoveate" groups of Mischocyttarus (see figs. 174-180) was in some sense expected based on taxonomic tradition (see for example constitution of Megacanthopus sensu Richards, 1945), a monophyletic group formed by the subgenus Omega and the species-groups of $M$. surinamensis and $M$. prominulus (of Haplometrobius) verified in all kinds of analyses is a new result of this study. Support for this clade in weighted analysis $(\mathrm{k}=1)$ comes mainly from three characters (see also Apendix 2): character 8: $0>4$ (apex of female clypeus narrowly rounded); character 54: $0>5$ (aedeagus from above with distal portion narrow, then suddenly expanding to form a well differentiated apex distinctly angular at sides); character 56:2>1 (sclerotized portion of the base of the aedeagus as a linear elongate lobe developed anteriorly up to the paramere basal processes). In some trees, characters 52: 1>3 (shape of digitus) and 58: $3>2$ (hairs of parameral spine) also appeared as synapomorphies. Only transformations in characters 52, 54, and 56 are unique within Mischocyttarus. However, state 3 of character 52 actually occurs only in part of the group of M. surinamensis and in the group of M. prominulus. States 5 and 1 of characters 54 and 56 respectively occur in the whole clade, but are changed in some elements of Omega (the first character in an undescribed species related to $M$. buyssoni, and the second in the group of $M$. punctatus). Other unique transformations

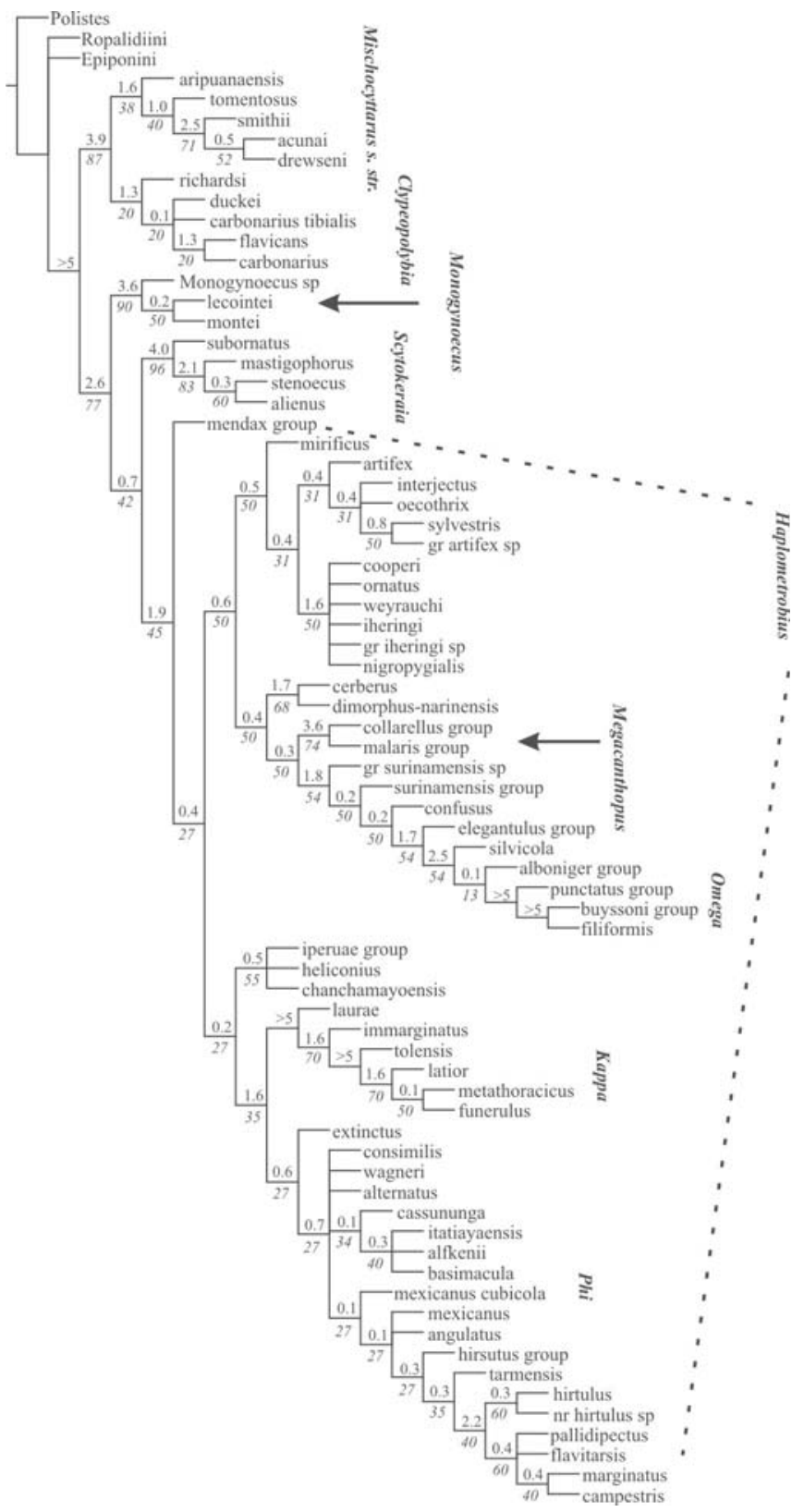

Fig. 177. Strict consensus of 9 trees $(F i t=388.2)$ found under implied weights $(\mathrm{k}=3)$ with Pee-Wee 3.0 for Mischocyttarus major species groups. Absolute (above) and relative (below) Bremer supports are presented for ingroup branches, except when the value exceeded the upper limit considered (i.e. $>100 \%$ ).

supporting progressively less inclusive groups within the component are in character 6: $0>1$ (frontal region of the head in female strongly protuberant; present in the M. prominulus and $M$. punctatus groups), and in character 41: $0>1$ (first metasomal sternum without a dense cover of short hairs, tegument shining; present in part of the M.prominulus group and in subgenus Omega).

A close relationship between the species-groups of $M$. iheringi (in the present sense) and $M$. artifex was suggested in all weighted analyses. Some of the topologies presented $M$. 
mirificus as an outer element sister to a clade formed by the iheringi group plus a major subset of the artifex group, i.e. making the latter paraphyletic. In certain number of trees found with k=3, subgenus Megacanthopus appeared as part of this whole component, being sister to a monophyletic artifex group.

In the subgenus $P h i$, the only patterns repeated across weighted analyses are the sister-group relationship between M. extinctus and remaining species, and the clade formed by a small subset of the species of Richards's 1978 group of $M$. flavitarsis (Figs. 174, 176-180).

\section{Unseen forms}

A considerable number of described species of Mischocyttarus could not be examined. As already stated, $M$. (Monogynoecus) onorei Cooper could possibly be important for inference of primitive states in the genus. Two other significant missing pieces of evidence are $M$. minifoveatus Cooper (1998a) and M. tertius Richards (1978). In both cases, the male is unknown, and female descriptions are incomplete to the point of making impractical the inclusion of these species as terminals in the study. Mischocyttarus minifoveatus seems to be similar to species of the $M$. mendax group, differing mainly by the shape of clypeus being wider than high, with the apex "pointed", and by the pronotal anterior margin being strongly raised. The posterior ocelli also seem to be more separated than in the mendax group. The species is here assigned to a new monospecific group of $M$. minifoveatus.

Mischocyttarus tertius was described only from the two female types, without information of nest. It has a set of pronotal features referable to some species of the $M$. iheringi group, i.e. with anterior margin raised and reflexed, secondary margin present, and with a "small but deep" fovea. The well separated posterior ocelli also indicate similarity with another species from Mato Grosso treated by Richards (1978) under the name $M$. undulatus. Richards's emphasis on the clypeal apex of $M$. tertius being "not at all truncate" possibly relates to the author's intention of discriminating the species among others of the artifex group to which it was originally assigned. The species is here tentatively assigned to the M. iheringi group.

Redefinition of limits and contents of several speciesgroups

As indicated in the works of Cooper (1996a, 1996b, 1997a), and Silveira $(1998,2002,2004)$ who made extensive corrections to the limits of some of the subgenera and species-groups treated by Richards (1978), several of these groups are not properly defined, i.e. they lack an efficient diagnosis based on unique characters or combinations of characters. Most of Richards's species-groups are parts of $P h i$ and Haplometrobius, the largest subgenera in species numbers. Here I present an annotated register of the species-groups along with a list of their constituent species (or probable species for those not actually examined, or cases in which males are unknown and critical for correct assigment), and respective diagnoses. The revised groups are largely based on results of

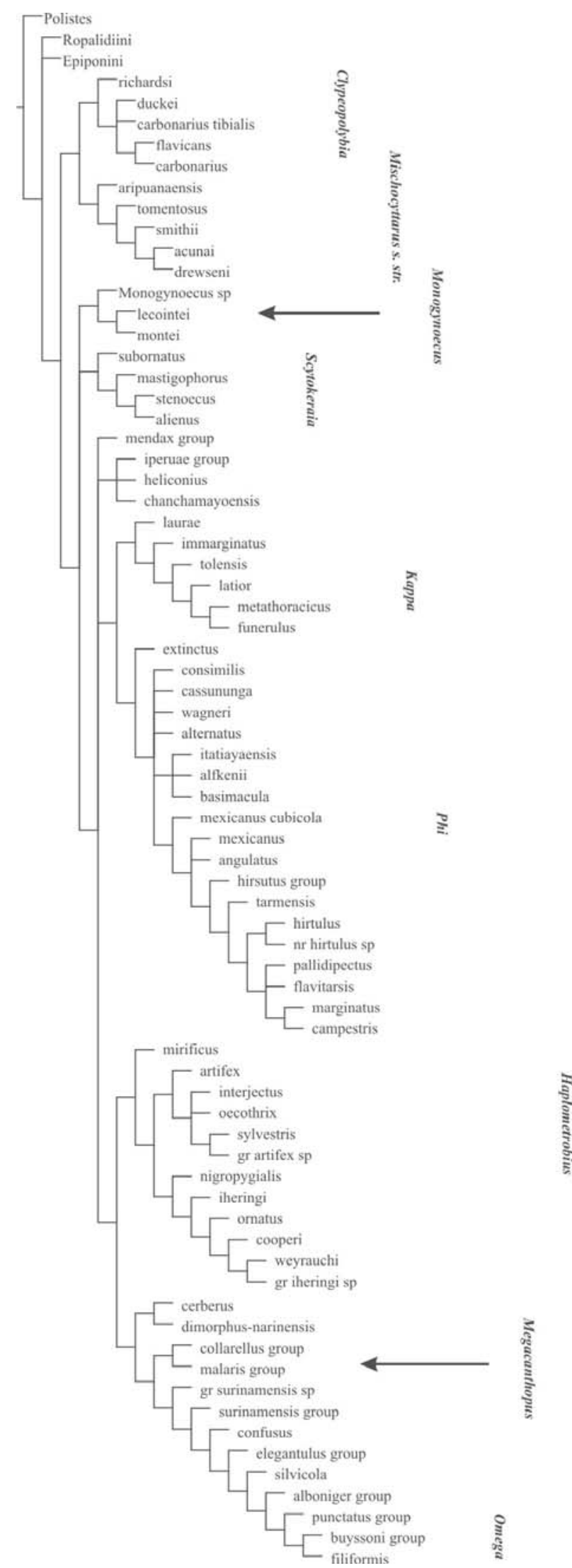

Fig. 178. Strict consensus of 18 trees (Fit $=413.9)$ found under implied weights $(\mathrm{k}=4)$ with Pee-Wee 3.0 for Mischocyttarus major species groups. 
the present study, but monophyly is eventually relaxed as a critetion of validity of groups, since the main aim is to preliminarily describe morphological diversity in the genus and facilitate further studies.

\section{Subgenus $P h i$}

1) group of M.flavitarsis: M. fisheri Snelling, M. bruneri Bequaert \& Salt, M. campestris Raw, M. marginatus (Fox), $M$. chapadae (Fox), M. pallidipectus (Smith), M. hirtulus Zikán, M. inca Zikán, M. duidensis Richards, M. oreophilus Zikán (?), M. barbatulus Richards (?), M. rufipes Zikán (?),

Pronotal secondary margin absent, anteromedian lamella narrow; female clypeal apex narrowly rounded; pronotal carina reduced; male mandible very robust, apical teeth very strong; male gena as wide as in female; metanotum distinctly convex; inner claw of hind tarsus very sharp.

\section{2) group of M.tarmensis Richards.}

Pronotal secondary margin absent, anteromedian lamella narrow; female clypeal apex round; pronotal carina reduced; male mandible and gena normal; apex of male antenna hooklike; propodeum less swollen and without pronounced posterior concavities at sides; body hairs long and conspicuous especially on head and propodeum.

3) group of M. hirsutus Richards: M. commixtus Richards, M. mixtus Richards, M. ecuadorensis Zikán, M. barbatus Richards, M. peduncularius Zikán, M. transandinus Richards, M. rufomaculatus Richards (?).

Pronotal secondary margin present, obtuse, not strongly projecting over anteromedian lamella; female clypeal apex narrowly truncate; male mandible and gena normal; apex of male antenna hook-like; body hairs long and conspicuous especially on head and mesosoma, erect hairs on frons and mesoscutum measuring nearly two occelar diameters; sculpture strong; black species commonly with diffuse reddish marks on mesosoma.

4) group of $M$. mexicanus (de Saussure): M. angulatus Richards, " $M$. angulatus morph ictericus" Richards, $M$. costaricensis Richards; $M$. mexicanus cubicola Richards, $M$. phthisicus (F.), M. cubensis (de Saussure).

Pronotal secondary margin obtuse or sharp; female clypeal apex narrowly truncate; male mandible and gena normal; apex of male antenna with articles very broad and short; metanotum rather convex; body hairs commonly long and conspicuous especially on head and propodeum (short in M. phthisicus, $M$. mexicanus cubicola, and probably M. cubensis).

5) group of $M$. alfkenii (Ducke) and M. basimacula (Cameron): M. mamirauae Raw, M. flavicornis Zikán, $M$. paraguayensis Zikán, M. bahiae Richards, M. aracatubaensis Zikán, M. gilvus Zikán;

Pronotal secondary margin sharp and projecting over anteromedian lamella; female clypeal apex narrowly truncate; male mandible and gena normal; apex of male antenna with

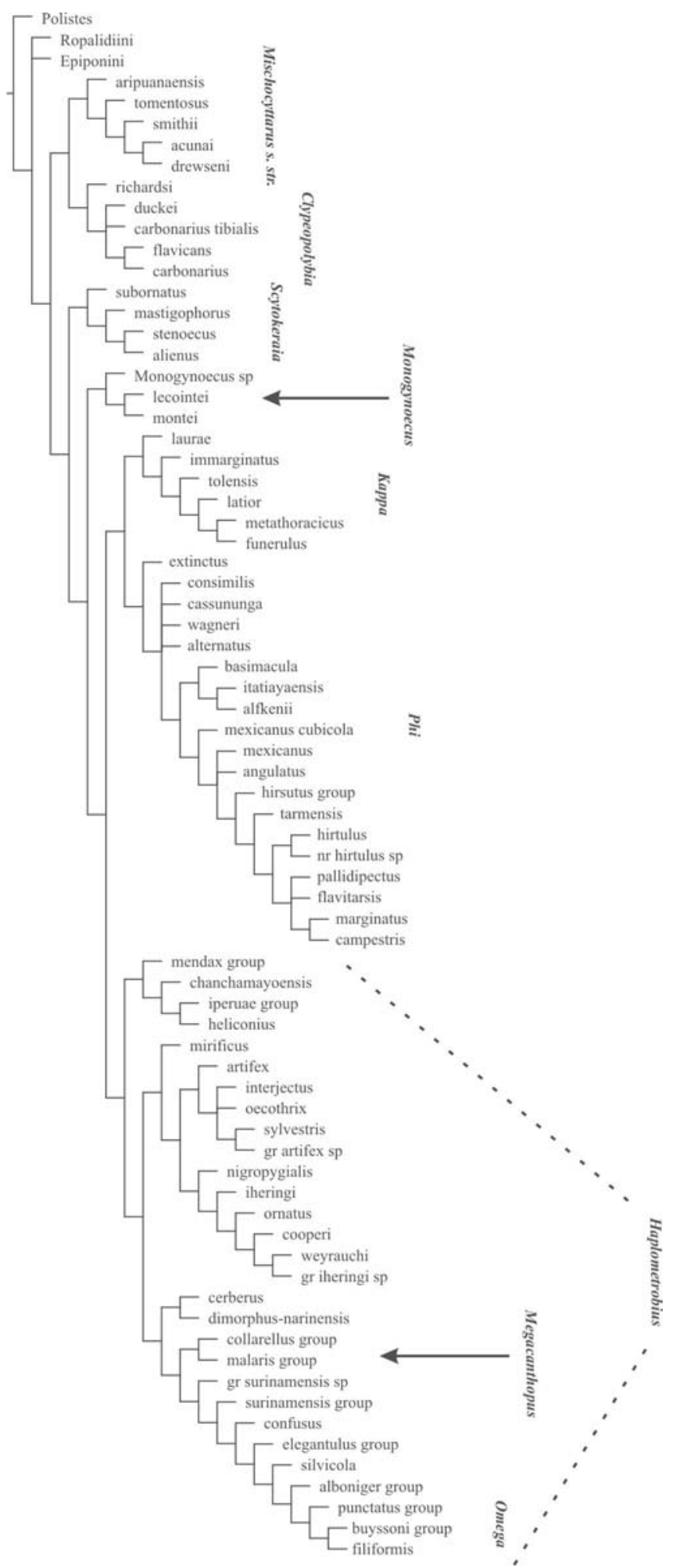

Fig. 179. Strict consensus of 6 trees $(F i t=433.6)$ found under implied weights $(\mathrm{k}=5)$ with Pee-Wee 3.0 for Mischocyttarus major species groups.

articles very broad and short, 13 one and a half times as long as wide at base; male clypeus touching eyes; metanotum noticeably flattened; body hairs shorter and less conspicuous. 
6) group of M. itatiaeyensis Zikán and M. costalimai Zikán: $M$. riograndensis Richards,

M. scitulus Zikán, M. infrastrigatus Zikán, M. fluminensis Zikán (?), M. similatus Zikán (?), M. catharinaensis Zikán (?), M. mutator Zikán (?), M. rivulorum (?), M. lules Willink (?).

Pronotal secondary margin sharp and projecting over anteromedian lamella; female clypeal apex narrowly truncate; male mandible and gena normal; apex of male antenna with articles broad and short, 13 two times as long as wide at base; male clypeus narrowly separated from eyes; metanotum noticeably flattened; body hairs shorter and less conspicuous.

7) group of M. wagneri (du Buysson) and M. alternatus Zikán: M. imeldai Zikán, M. plaumanni Zikán, M. brackmanni Zikán, M. proximus Zikán, M. mourei Zikán, M. lanei Zikán, M. declaratus Zikán, M. cabauna Zikán, M. confirmatus Zikán, M. petiolatus Richards (?);

Pronotal secondary margin sharp and projecting over anteromedian lamella; female clypeal apex narrowly truncate; male mandible and gena normal; apex of male antenna hooklike; male clypeus touching eyes, covered with very conspicuous dense silvery pubescence; pronotal carina centrally reduced; metanotum rather convex; metasomal first tergum as long or longer than hind femur + trochanter.

8) group of M. cassununga (von Ihering) and M. consimilis Zikán: M. cearensis Richards, M. extinctus Zikán: M. crypticus Zikán, M. cryptobius Zikán; M. lilae Willink; M. mimicus Zikán (?);

Pronotal secondary margin sharp and projecting over anteromedian lamella; female clypeus relatively narrow, apex narrowly truncate or rounded; male mandible and gena normal; apex of male antenna hook-like; hairs on posterior ventral part of gena short and inconspicuous; metanotum rather convex; male clypeus touching eyes, silvery pubescence not very conspicuous; pronotal carina centrally reduced.

\section{(Former Subgenus Haplometrobius)}

1) group of Mischocyttarus minifoveatus Cooper (1998a).

Anterior margin of proepisternum not reflexed; pronotal secondary margin absent, anteromedian lamella strongly raised, carina not projecting at sides, fovea present; clypeus a liitle wider than high, apex pointed; occipital region unmarginned.

2) group of Mischocyttarus mendax Richards (see Cooper, 1996b): M. montivagus Cooper, M. moronae Cooper, M. tectus Cooper, M. occultus Cooper, $M$. reclusus Cooper, $M$. tunari Cooper.

Anterior margin of proepisternum not reflexed; pronotal secondary margin absent, carina angularly slightly elevated at center, not projecting at sides, fovea present; female clypeal apex bidentate; occipital region narrow and unmarginned; male antenna elongate, without erect hairs; digitus short and round.

3) group of Mischocyttarus heliconius Richards:

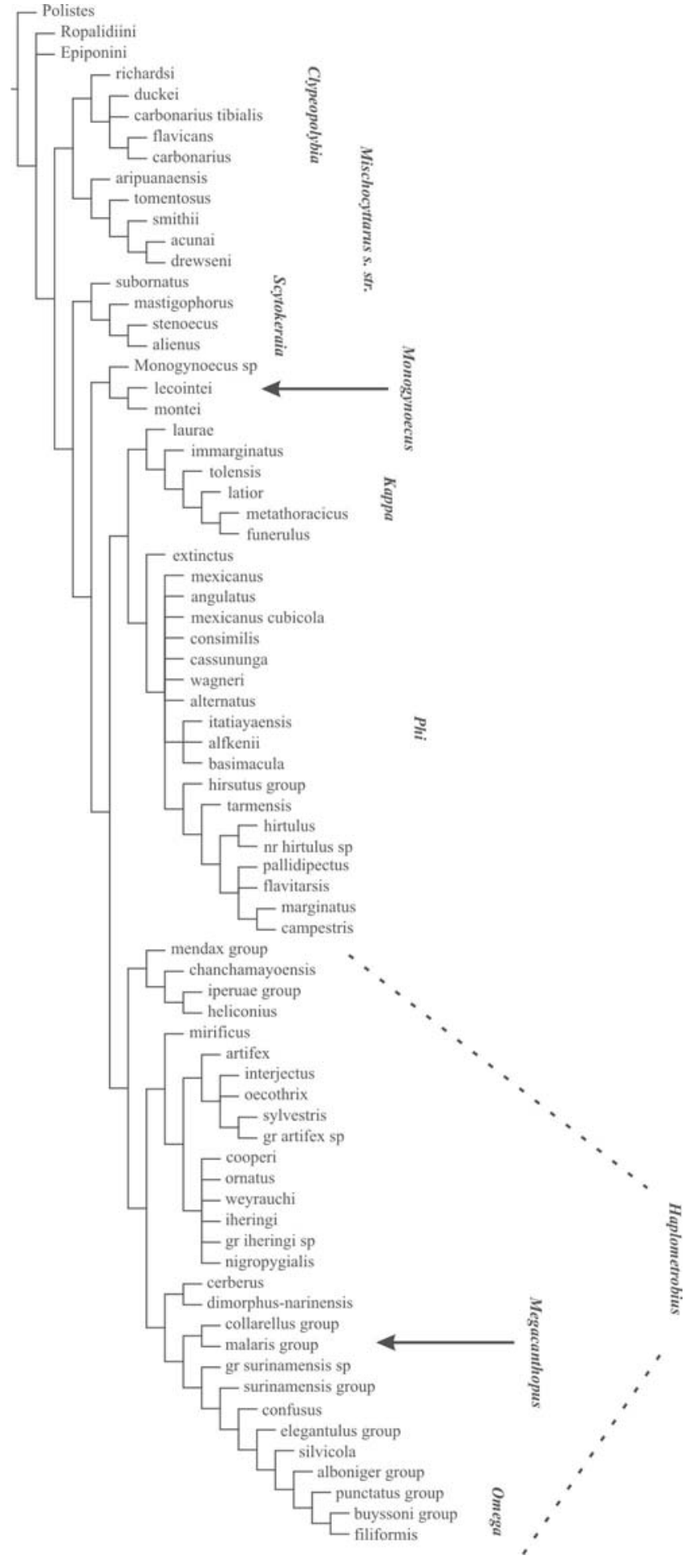

Fig. 180. Strict consensus of 72 trees $($ Fit= 450.5) found under implied weights $(\mathrm{k}=6)$ with Pee-Wee 3.0 for Mischocyttarus major species groups.

Mischocyttarus heliconius iperuae Richards, $M$. chanchamayoensis Richards, M. sericeus Richards, M. piger Richards, M. undulatus sensu Richards (1945).

Anterior margin of proepisternum not reflexed; pronotal 
secondary margin absent, anteromedian lamella reflexed; fovea present; female clypeal apex narrowly rounded; occipital region carinate; male antenna always elongate, without erect hairs, apical part narrow and spirally rolled.

4) group of Mischocyttarus surinamensis (de Saussure): M. tricolor Richards, M. decimus Richards, M. bahiaensis Zikán, M. hoffmanni Zikán, M. ignotus Zikán, M. garbei Zikán, $M$. confusus Zikán, M. melanoxanthus Richards, $M$. xanthocerus Richards, $M$. cleomenes Richards, M. paulistanus Zikán, $M$. confusoides Zikán, M. souzalopesi Zikán, $M$. claretianus Zikán; M. bequaertii Richards.

Anterior margin of proepisternum raised and reflexed; pronotal secondary margin absent, humeral region projecting laterally, fovea absent; clypeal apex narrowly rounded; occipital region just compressed dorsally, not really carinate; male antenna nearly always elongate, with erect hairs, apical part very narrow and spirally rolled (short with apex hook-like in only one undescribed species from Panamá).

5) group of Mischocyttarus prominulus Richards: $M$. pallidus Zikán, M. silvicola Zikán, M. melanoleucus Richards, M. elegantulus Zikán, M. annulatus Richards, M. alboniger Richards, $M$. tenuis Richards;

Anterior margin of proepisternum raised and reflexed; pronotal secondary margin absent, anteromedian lamella strongly reflexed, humeral region projecting laterally, fovea absent; female clypeal apex narrowly rounded; occipital region distinctly carinate; male antenna always with apex short and hook-like; posterior part of the head around occipital foramen produced into a shallow cavity with a smoothly rounded boundary, never sharply margined; hairs on posterior ventral part of gena short and inconspicuous.

6) group of Mischocyttarus cerberus (Ducke) (see also Silveira. 2004): M. illusorius Richards, M. nomurae Richards, M. peruanus Zikán, M. dimorphus Zikán, M. narinensis Cooper.

Anterior margin of proepisternum raised and reflexed; pronotal secondary margin sharp; fovea absent; inner claw of hind tarsus narrow, nerver spoon-shaped; male antenna always elongate, apical part very narrow and spirally rolled, no antennomere with erect hairs; male mandible with tooth 1 (posteriormost) much larger than the others; digitus very long but sac-like, not "digitiform"; paramere spine with moderately numerous elongate hairs.

7) group of Mischocyttarus iheringi Richards: $M$. weyrauchi Zikán, $M$. saussurei Zilán, $M$. vredeni Richards, $M$. naumanni Richards, M. cooperi Richards, M. longicornis Zikán, $M$. nigropygialis Zikán, $M$. macarenae Cooper, $M$. ornatus Zikán, $M$. travassosi Zikán, $M$. curitybanus Zikán, $M$. undulatus sensu Richards (1978, p. 413-414; in part, only specimens from Mato Grosso, Brazil).

Anterior margin of proepisternum not reflexed; pronotal secondary margin sharp; fovea absent in nearly all instances

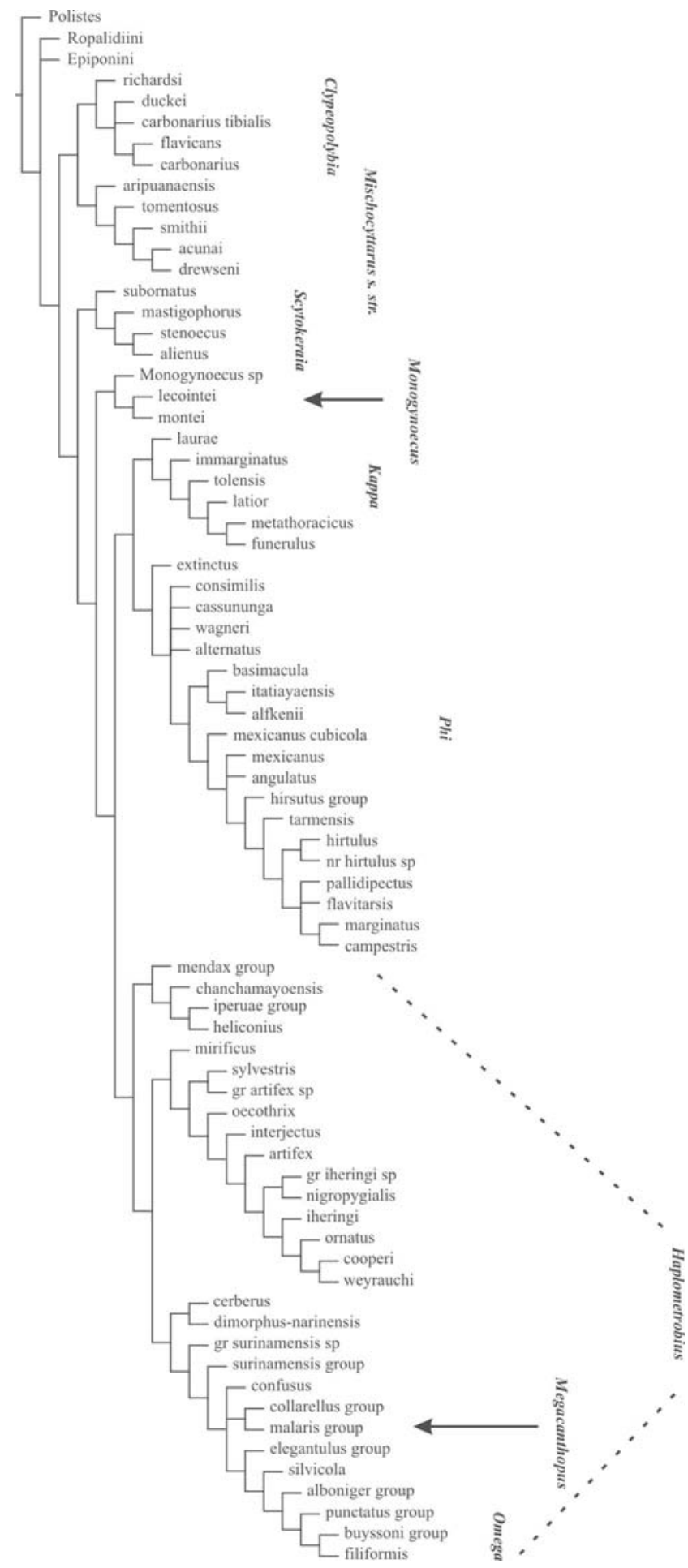

Fig. 181. Strict consensus of 3 trees found under implied weights $(k=1)$ with TNT 1.0 for Mischocyttarus major species groups.

except for a residual one in $M$. tertius and $M$. undulatus s. Richards; female clypeal apex narrowly truncate; occipital region most often compressed or carinate; male antenna always elongate, with erect hairs, apical part very narrow and spirally rolled; male aedeagus short and absolutely straight in lateral view, ventral process as a rounded lobe contorted inwards, 
without teeth; digitus short, with a rounded shape, rarely triangular.

8) group of Mischocyttarus artifex (Ducke): M. sylvestris Richards, M. lemoulti (Buysson), M. schadei Zikán, $M$. ypiranguensis Fonseca, M. mirificus Zikán, M. peruviensis Richards, $M$. thrypticus Richards, $M$. chloroecus Cooper, $M$. leucoecus Cooper, M. filipendulus Cooper, M. maculipennis Cooper, $M$. polymorphus Cooper, $M$. reflexicollis Zikán, $M$. capichaba Zikán, $M$. interjectus Zikán, $M$. giffordi Raw, $M$. oecothrix Richards, M. synoecus Richards, M. interruptus Richards, M. nigroclavatus Zikán, M. undulatus (Ducke).

Anterior margin of proepisternum not reflexed; pronotal secondary margin sharp; fovea absent; clypeal apex bidentate; male antenna moderately elongate with distal articles often distinctly flattened below and not much longer than wide in dorsal view, in a few species with apex short and hook-like (mirificus and allies), frequently with conspicuous erect hairs; male aedeagus with ventral process as a large angular lobe; digitus triangular; paramere spine nearly glabrous, or with short hairs at the apex (mirificus and allies).

A new classification for Mischocyttarus

Haplometrobius Richards was the only subgenus of Mischocyttarus whose monophyly was consistently negated in this study. Acceptance of results obtained in the unweighted analysis would lead also to rejection of Phi (see Fig. 173). However, this latter result was contradicted by all analyses using weights, what seems to be sufficient reason for keeping such a otherwise well delimited group. The consensus tree of figure 174 (from weighted analysis, $\mathrm{k}=1$ ), together with relative branch support values are valuable guides to decide about which major clades and species-groups should possibly be reflected in a classification of the genus. If enlargement of the concept of Omega for inclusion of the M. prominulus and $M$. surinamensis species-groups seems unavoidable, doing the same for Kappa to include the M. heliconius group is probably not so straightforward given that character support is in this case weak, involving only two relatively variable features (occipital carina and clypeal apex). Equally weak is character support for the component linking elements of the $M$. artifex and $M$. iheringi groups, mainly based on shape of pronotal anterior margin and male antennal hairs, which vary broadly among Haplometrobius groups.

The classification proposed here preserves validity of all previous subgenera except Haplometrobius (sensu Richards, 1978). If the analyses have shown a good level of confidence in monophyly of some of the Haplometrobius less inclusive groups, relationships among them are largely uncertain. The solution adopted here for this problem is to use the name Haplometrobius narrowly for the M. iheringi group only, containing the type species $M$. iheringi Zikán, and raising to subgenus level other species-groups whose monophyly has been effectively tested, i.e. the $M$. cerberus group and the major part of the $M$. artifex group, with other former Haplometrobius groups being treated as incertae sedis (see

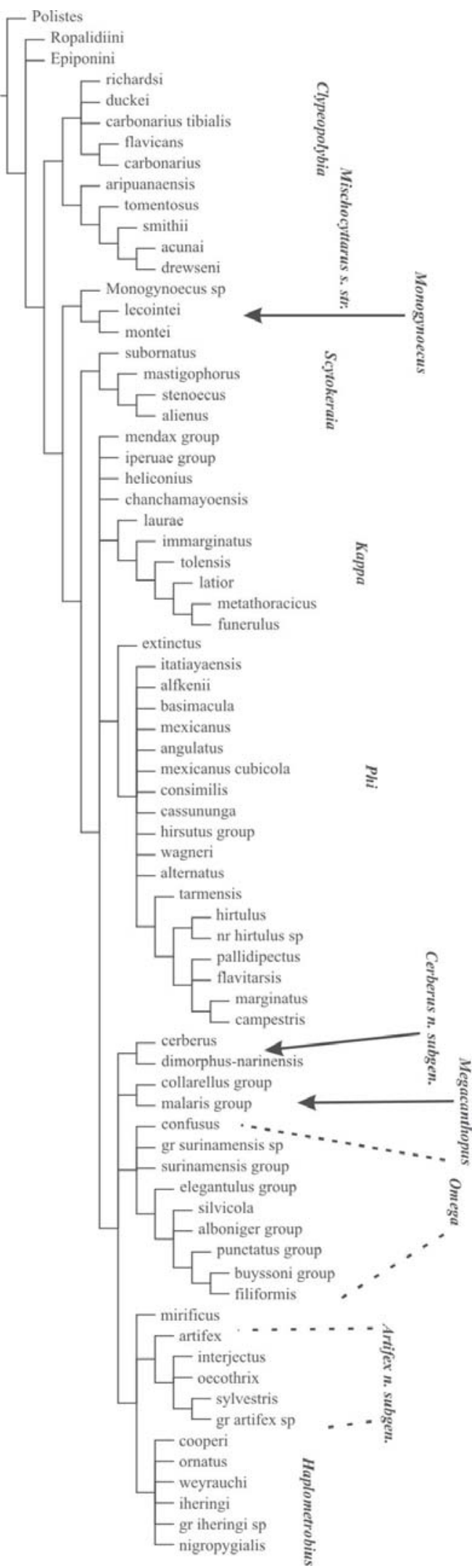

Fig. 182. Strict consensus of trees found under implied weights with Pee-Wee 3.0, values of the constant of concavity varying from 1 to 3 . Subgenera with their limits and content as conceived in the classification presented in this work. 
below). If Mischocyttarus mirificus Zikán and a few close allies (M. ypiranguensis, Fonseca; M. schadei Zikán; M. thrypticus Richards) must properly be considered uncertain within the new subgenus created for the $M$. artifex group (see below), it should be stressed that $M$. mirificus actually shows the large triangular ventral aedeagal process, a distinct unique feature of the $M$. artifex group, and also constructs the very elongate nests so typical in the group.

The classificatory decisions are in fairly agreement with the consensus between the trees obtained in weighted analyses with values of " $k$ " equal to 1, 2 and 3 (Fig. 182). If the criticism could be made of excessive splitting regarding recognition of three relatively small species-groups (a reduced Haplometrobius and two new subgnera; see below), the alternative situation of a single very large subgenus containing a very heterogeneous array of (afoveate) species is probably worse. Furthermore, the name Omega de Saussure, the oldest available for such a group would have as synonym at least one very distinctive taxon, Megacanthopus which should then be treated as a species-group (in addition to Omega itself in its Richards's 1978 "Monacanthocnemis" sense; a fact also occurring in the context of the alternative solution proposed here). However, knowledge of the relations among such large clades as Phi and Kappa (and the afoveate component) is certainly a prerequisite to making the best decisions at this level of inclusiveness. All that can be done now, and that would be probably useful is to name informally the two basalmost clades within the genus, for which I suggest the names "Saussurea" for Mischocyttarus s. str. + Clypeopolybia, and "Duckea" for the large component formed by the remaining groups.

Genus Mischocyttarus de Saussure, 1853.

Subgenus Mischocyttarus de Saussure, 1853: 19.

Type species: Zethus labiatus Fabricius, 1805, by designation of Ashmead, 1902.

Subgenus Clypeopolybia Brèthes, 1923: 16.

Type species: Clypeopolybia duckei Brèthes, 1923 (=Polistes flavicans Fabricius, 1804), by monotypy.

Subgenus Monogynoecus Richards, 1941: 126.

Type species: Megacanthopus lecointei Ducke, 1904, by original designation.

Subgenus Scytokeraia Cooper, 1997a: 117.

Type species: Mischocyttarus mastigophorus Richards, 1978 , by original designation.

Subgenus Phi de Saussure, 1854: 183.

Type species: Vespa phthisica Fabricius, 1793, by designation of Bequaert, 1943.

Monocyttarus Richards, 1978: 307. Type species: Polybia flavitarsis de Saussure, 1854, by original designation; synonymy by Carpenter \& Day, 1988.
Subgenus Kappa de Saussure, 1854: 200.

Type species: Polybia injucunda de Saussure, 1824, by designation of Bequaert, 1933.

Subgenus Haplometrobius Richards, 1978: 389. [= group of $M$. iheringi Richards]

Type species: Mischocyttarus iheringi Zikán, 1935, by original designation.

Subgenus Artifex subgen. n. [= group of $M$. artifex Ducke]

Type specie: Mischocyttarus artifex Ducke, 1914; absolute tautonymy.

Subgenus Cerberus subgen. n. [= group of $M$. cerberus Ducke]

Type species: Mischocyttarus cerberus Ducke, 1918; absolute tautonymy.

Subgenus Omega de Saussure, 1854: 206. (sensu this work)

Type species: Polybia filiformis de Saussure, 1854, by monotypy.

Subgenus Megacanthopus Ducke, 1904: 358.

Type species: Megacanthopus collaris Ducke, 1904, by designation of Bequaert, 1933.

Incertae sedis group of Mischocyttarus heliconius Richards group of Mischocyttarus mendax Richards Mischocyttarus minifovetaus Cooper

Key to subgenera and species-groups of Mischocyttarus

1. Base of fore and mid femora with a ring-like sulcus; anterior two-thirds of mesoscutal margin adjacent to tegula reduced; first metasomal segment often strongly compressed, lateral profile very deep with a prominent ventral angle posterior to the spiracle, tergal margins closely approximated below at this point, sternum with a "strangled" appearance; male antenna linear not tapering distally; digitus of male genitalia distinctly pilose

Base of fore and mid femora without a ring-like sulcus; mesoscutal margin adjacent to tegula nearly always complete; first metasomal segement differently shaped; male antenna nearly always tapering distally; digitus of male genitalia approximately glabrous

\section{3}

2(1). Lateral symmetric indentations of the female clypeus rather shallow; female fore femur in section with a roughly round contour; propodeum with anterior medial surface rather strongly raised, median furrow deep and distinctly triangular; male aedeagus very wide from base to apex; nest comb circular with central peduncle

............ Subgenus Mischocyttarus s. str. de Saussure. 
Lateral symmetric indentations of the female clypeus very deep; female fore femur with posterior surface strongly flattened, with a sharp edge ventrally sometimes "lamellate"; propodeum with anterior medial surface oblique, median furrow deep or shallow, linear; male aedeagus narrowing distally; nest comb polygonal with eccentric peduncle ..... .. Subgenus Clypeopolybia Brèthes.

3(1). Frons and interantennal area in female looking depressed, antennal sockets close to each other, separated by a distance no longer than their height, socket aperture facing forwards, with fairly circular contour, its marginal lamella high and "free"; pronotum humeral region nearly always without vestiges of angle, contour seen from above practically continuous with the anterior region of the pronotum, carina often strongly reduced, fovea very small or absent; male mandible with four apical teeth, antennal apex short hook-like; aedeagus very wide from base to apex, distal portion short and dorsally flattened, with parallel sides; aedeagal ventral process as a very long narrow lobe

Subgenus Monogynoecus Richards.

Frons and upper portion of interantennal area in female more swollen and raised, socket aperture directed more laterally, contour not regularly circular, marginal lamella looking as if turned and compressed outwards; humeral region with noticeable angle (if round, then carina exceptionally developed), fovea variable; male mandible with four or three teeth, antenna variable; male aedeagus and ventral process differently shaped .... 4

4(3). Inner margin of fore coxa very low, not reflexed; female clypeus with apex widely truncate and bidentate; posterior dorsal part of the head narrow, strongly dipping backwards behind eyes and ocelli; anterior region of pronotum without a secondary margin, anteromedian lamella narrow, humeral region not forming lateral lobe, carina usually low; tooth 1 of male mandible with external surface convex, similar to female, its posterior border curved; male antenna elongated, article 13 slender, strongly compressed, often acuminate ...... Subgenus Scytokeraia Cooper. Inner margin of fore coxa more often high and reflexed, if very low then the female clypeal apex not at all bidentate; posterior dorsal part of the head wider; pronotum variable; tooth 1 of male mandible planar, distal portion often with a linear aspect, unlike that of female; male antenna variable, article 13 differently shaped, rarely compressed 5

5(4). Pronotal carina total or partially reduced at center, not lamellate there; fovea present; first metasomal segment with a shallow lateral profile, without a prominent ventral angle posterior to the spiracle; male digitus quite long, digitiform; male antenna never with erect conspicuous hairs 6

Pronotal carina continuous from side to side (if interrupted centrally then the fovea is absent); first metasomal segment laterally more often with a noticeable ventral angle posterior to the spiracle; male digitus nearly always shorter, round or triangular, never digitiform; male antenna with or without erect hairs 14

6(5). Anterior margin of proepisternum elevated and strongly reflexed, forming a very wide and freely detached lateral collar; occipital region often carinate; posterior ocelli nearly always widely separated, positioned as basal vertices of a low triangle; male mandible with three teeth; male antenna with well developed tyloids; larvae with just one abdominal appendix-like process Subgenus Kappa de Saussure.

Anterior margin of the proepisternum low, not reflexed; occipital region unmargined, not carinate; posterior ocelli never so widely separate; male mandible with four teeth; male antenna nearly always with tyloids reduced; larvae with two abdominal appendix-like processes (Subgenus Phi de Saussure) 7

7(6). Pronotal secondary margin absent, anteromedian lamella narrow not raised; pronotal carina reduced ............ 8

Pronotal secondary margin present, obtuse or sharp, anteromedian lamella wider; pronotal carina reduced or not . ... 9

8(7). Female clypeus with apex narrowly rounded; male mandible very robust, apical teeth very strong; male gena as wide as in female; metanotum distinctly convex; inner claw of hind tarsus strictly sharp ........ ............ group of M. (Phi)flavitarsis (de Saussure).

Female clypeus with apex wider round; male mandible and gena normal; metanotum less convex; inner claw of hind tarsus less strictly sharp group of M. (Phi) tarmensis Richards.

9(7). Apex of male antenna pointed, hook-like 10 Apex of male antenna linear with articles broad and short

10(9). Pronotal secondary margin low, obtuse, not strongly projecting over anteromedian lamella; body hairs long and conspicuous especially on head and mesosoma, erect hairs on frons and mesoscutum measuring nearly two occelar diameters; sculpture strong; black species commonly with diffuse reddish marks on mesosoma ...... group of M. (Phi) hirsutus Richards.

Pronotal secondary margin sharp and strongly projecting over anteromedian lamella .. 11 
11(10).Hairs on posterior ventral part of gena normally long and conspicuous; female clypeus with apex narrowly truncate; male clypeus covered with very conspicuous dense silvery pubescence; propodeal median furrow wide and shallow; metasomal first tergum as long or longer than hind femur + trochanter group of $M$. (Phi) wagneri (du Buysson) and M. (Phi) alternatus Zikán.

Hairs on posterior ventral part of gena short and inconspicuous; female clypeus with apex narrowly truncate or rounded; male clypeus with silvery pubescence not so conspicuous; propodeal median furrow longer and deeper; metasomal first tergum shorter .......................... group of M. (Phi) cassununga (von Ihering) and M. (Phi) consimilis Zikán.

12(9). Metanotum rather convex; body hairs commonly long and conspicuous especially on head and propodeum (short in M. phthisicus, M. mexicanus cubicola, and probably $M$. cubensis) ..... group of M. (Phi) mexicanus (de Saussure).

Metanotum more flattened; body hairs shorter and less conspicuous

13(9). Male clypeus touching eyes; male antennal article 13 very short, one and a half times as long as wide at base .................................. group of M. (Phi) alfkenii (Ducke) and M. (Phi) basimacula (Cameron).

Male clypeus narrowly separated from eyes; male antennal article 13 slightly longer, two times as long as wide at base or a little more ........ group of M. (Phi) itatiaeyensis Zikán and M. (Phi) costalimai Zikán.

14(5). Pronotum laterally with a fovea, pronotal anterior region without secondary margin, carina tending to be angularly raised at center; male antenna never with conspicuous erect hairs ... ... 15

Pronotum nearly always without a fovea, anterior region with or without secondary margin, carina differently shaped at center (rarely if pronotum with fovea, then anterior region with a sharp secondary margin, and male antenna with conspicuous erect hairs) ......... 17

15(14).Occipital region carinate or with compressed edge; margin of hypostoma often with lamella elevated near articulation of mandible; pronotal anteromedian lamella always raised and reflexed; medium to large species ................ group of M. heliconius Richards.

Occipital region unmargined; margin of hypostoma with lamella low; pronotal anteromedian lamella variable; small species 16

16(15).Female clypeus with apex truncate and weakly bidentate; pronotal anteromedian lamella narrow not noticeably raised .......................... group of M. mendax Richards.

Female clypeus with apex pointed; pronotal anteromedian lamella strongly raised group of M. minifoveatus Cooper.

17(14).Aanterior margin of proepisternum elevated and strongly reflexed, forming a very wide and freely detached lateral collar 18

Anterior margin of proepisternum not strongly reflexed 23

18(17).Anterior region of pronotum with a sharp secondary margin; inner claw of hind tarsus narrow, nerver spoon-shaped; male antenna always elongate, apical part very narrow and spirally rolled, no antennomere with erect hairs; male mandible with tooth 1 (posteriormost) much larger than the others; male digitus very long but sac-like, not "digitiform" subgenus Cerberus subgen. $\mathrm{n}$

Anterior region of pronotum never with secondary margin; inner claw of hind tarsus wider, often spoonshaped; male antenna variable; male mandible with tooth 1 (posteriormost) normal, not enlarged; male digitus variable 19

19(18).Humeral region of pronotum with a distinct rounded contour; pronotal carina strongly convex, lamella very high, usually diminishing gradually at sides; pronotal anteromedian lamella nearly always strongly relfexed and ending laterally in a hook . subgenus Megacanthopus Ducke.

Humeral region of pronotum angled laterally, never with rounded contour; pronotal carina straight or concave; pronotal anteromedian lamella not produced laterally into a hook; male aedeagus from above nearly always with distal portion suddenly expanded and distinctly angular laterally, base of the aedeagus a linear elongate lobe developed anteriorly up to the paramere basal processes

(subgenus Omega de Saussure) 20

20(19).Posterior part of the head around occipital foramen produced into a deep cavity below, its ventral portion horizontal, sharply margined, like a shelf; paramere spine of male genitalia nearly glabrous ................. 21

Posterior part of the head around occipital foramen produced into a shallow cavity with a smoothly rounded boundary; paramere spine of male genitalia with long conspicuous hairs 22

21(20).Proepisternum with a pre-marginal raised crest (double margined); male antenna short, apex hook-like; nest comb vertical with one to three elongated rows of cells .......... group of M. (Omega) punctatus (Ducke).

Proepisternum without a pre-marginal raised crest (simple margined); male antenna elongated, spirally rolled; nest comb not elongated .......... group of M. (Omega) filiformis (de Saussure) 
22(20).Frontal region of female protuberant; occipital region carinate, usually blackened

.............. group of M. (Omega) prominulus Richards

Frontal region of female normal, not noticeably protuberant; occipital region at most with a dorsal compressed edge ...... group of M. (Omega) surinamensis (de Saussure).

23(17).Female clypeus with apex bidentate; male mandible often with tooth 1 very elongated; male aedeagus curved in lateral view, ventral process as a large triangular lobe; nest often with elongated vertical comb ......... subgenus Artifex subgen. n

Female clypeus never bidentate; male mandible with tooth 1 normal, not very elongated; male aedeagus straight in lateral view, ventral process as a small rounded lobe contorted inwards; nest variable, rarely with elongated vertical comb subgenus Haplometrobius Richards.

Acknowledgments. This paper is part of a doctorate thesis presented at the "Museu de Zoologia da Universidade de São Paulo". I am very grateful to Dr. Carlos Roberto Brandão, Dr. Sérvio T. Pires Amarante, Dr. Eliana Cancello, Dr. Sergio Vanin, and many other teachers and colleagues in S. Paulo and Belém for generous help in many aspects of the work. Dr. James M. Carpenter kindly revised the manuscript. I am also grateful to Dr. Junichi Kojima, Dr. Carlos Sarmiento and the curators of the various institutions for the material borrowed for this study.

\section{REFERENCES}

Arnett, R. H; G. A. Samuelson \& G. M. Nishida. The Insect and Spider Collections of the World. Gainesville, Sandhill Crane Press, 310 p. Arévalo, E.; Y. Zhu; J. M. Carpenter \& J. Strassmann. 2004. The phylogeny of the social wasp subfamily Polistinae: evidence from microsatellite flanking sequences, mitochondrial COI sequence, and morphological characters. BMC Evolutionary Biology 4:116.

Bequaert, J. 1933. The neartic social wasps of the subfamily Polybiinae (Hymenoptera: Vespidae). Entomologica Americana (n. ser.) 13: $87-150$.

Bequaert, J. 1937. Two Central American social wasps, accidentally introduced into the United States. Bulletin of the Brooklyn Entomological Society 32: 116.

Bequaert, J. 1943. New and imperfectly known neotropical Polybiinae (Hymenoptera, Vespidae). Journal of the New York Entomological Society 50: 295-308.

Bin, F.; F. Wäckers; R. Romani \& N. Isidoro. 1999. Tyloids in Pimpla turionellae (L.) are release structures of male antennal glands involved in courtship behaviour (Hymenoptera: Ichneumonidae). International Journal of Insect Morphology 28: 61-68.

Bremer, K. 1994. Branch support and tree stability. Cladistics 10: 295-304.

Brèthes, J. 1923. Primera contribución para el conocimiento de los Strepsipteros argentinos. Revista de la Facultad Nacional de Agronomía, Universidad de La Plata 15: $18 \mathrm{pp}$.

Carpenter, J. M. 1982. The phylogenetic relationships and natural classification of the Vespoidea (Hymenoptera). Systematic Entomology 7: 11-38.

Carpenter, J. M. 1987. Phylogenetic relationships and classification of the Vespinae (Hymenoptera: Vespidae). Systematic Entomology 12: 413-431.

Carpenter, J. M. 1988a. The phylogenetic system of the Stenogastrinae
(Hymenoptera: Vespidae). Journal of the New York Entomological Society 96: 140-175.

Carpenter, J. M. 1988b. Choosing among multiple equally parsimonious cladograms. Cladistics 41: 291-296.

Carpenter, J. M. 1991. Phylogenetic relationships and the origin of social behavior in the Vespidae, p. 7-32. In: Ross, K. G. \& Matthews, R. W. (eds.). The Social Biology of Wasps, Ithaca, Cornell University Press, $678 \mathrm{p}$.

Carpenter, J. M. 1993. Biogeographic patterns in the Vespidae (Hymenoptera): Two views of Africa and South America, p. 139155. In: Goldblatt, P. (ed.). Biological Relationships between Africa and South America, New Haven, Yale University Press.

Carpenter, J. M. 1996. Phylogeny and biogeography of Polistes, p. 18-57. In: Turillazzi, S. \& West-Eberhard, M. J. (eds.). Natural History and Evolution of Paper-Wasps, Oxford, Oxford University Press.

Carpenter, J. M. 1997. Phylogenetic relationships among european Polistes and the evolution of social parasitism (Hymenoptera: Vespidae, Polistinae). Mémoires du Muséum National d'Histoire Naturelle 173: 135-161.

Carpenter, J. M. 1999. Taxonomic Notes on Paper Wasps (Hymenoptera: Vespidae; Polistinae). American Museum Novitates 3259: 44 pp.

Carpenter, J. M. \& M. C. Day. 1988. Nomenclatural notes on Polistinae (Hymenoptera: Vespidae). Proceedings of the Entomological Society of Washington 90: 323-328.

Carpenter, J. M.; J. E. Strasssmann; S. Turillazzi; C. R. Hughes; C. R. Solís \& R. Cervo. 1993. Phylogenetic relationships among paper wasp social parasites and their hosts (Hymenoptera: Vespidae; Polistinae). Cladistics 9: 129-146.

Carpenter, J. M. \& J. W. Wenzel. 1988. A new species and nest type of Mischocyttarus from Costa Rica (Hymenoptera: Vespidae; Polistinae), with descriptions of nests of three related species. Psyche 95: 89-99.

Charnley Jr., H. W. 1973. The value of the propodeal orifice and the phallic capsule in Vespid Taxonomy (Hymenoptera, Vespidae). Bulletin of the Buffalo Society of Natural Sciences 26: 176.

Cooper, M. 1996a. The subgenus Monogynoecus Richards of Mischocyttarus de Saussure (Hym., Vespidae, Polistinae) with descriptions of two new species. Entomologist's Monthly Magazine 132: 23-28.

Cooper, M. 1996b. The mendax group of Mischocyttarus (Hym., Vespidae, Polistinae) with descriptions of new species. Entomologist's Monthly Magazine 132: 273-280.

Cooper, M. 1997a. A new subgenus of Mischocyttarus de Saussure (Hym., Vespidae). Entomologist's Monthly Magazine 133: 117-129.

Cooper, M. 1997b. The subgenus Megacanthopus Ducke of Mischocyttarus de Saussure (Hym., Vespidae), with a key and three new species. Entomologist's Monthly Magazine 133: 217-223.

Cooper, M. 1998a. Two new species of Mischocyttarus (Hym., Vespidae) with notes on some members of the iheringi group. Entomologist's Monthly Magazine 132: 89-93.

Cooper, M. 1998b. New species of the artifex group of Mischocyttarus de Saussure (Hym., Vespidae) with a partial key. Entomologist's Monthly Magazine 134: 293-306.

Dias-Filho, M. M. 1975. Contribuição à morfologia de larvas de vespídeos sociais do Brasil. Revista Brasileira de Entomologia 19: $1-36$.

Ducke, A. 1904. Sobre as vespidas sociaes do Pará. Boletim do Museu Goeldi 4: 317-374.

Ducke, A. 1905. Nouvelles contributions à la connaissance des vespides sociales de 1'Amérique du Sud. Revue d'Entomologie (Caen) 24: $5-24$.

Ducke, A. 1913. Zur Synonymie einiger Hymenopteren. Deutsche Entomologische Zeitschrift 1913: 330-333.

Ducke, A. 1914. Über Phylogenie und Klassifikation der socialen Vespiden. Zoologische Jahrbuchen Abteilung fur Systematik, Geographie und Biologic der Tiere 36: 303-330.

Ducke, A. 1918. Catalogo das vespas do Brazil. Revista do Museu 
Paulista 10: $314-374$

Farris, J. S. 1983. The logical basis of phylogenetic analysis, p. 7-36. In: Platnick, N. I. \& Funk, V. A. (eds.). Advances in Cladistics, 2. Proceedings of the second meeting of the Willi Hennig Society. New York, Columbia University Press, 218 p.

Fontal-Cazalla M. F.; M. L. Buffington; G. Nordlander; J. Liljeblad; P. R. Farré; J. L. N. Aldrey; J. P. Villar \& F. Ronquist. 2002. Phylogeny of the Eucoilinae (Hymenoptera: Cynipoidea: Figitidae). Cladistics 18: $154-199$

Gadagkar, R. 1991. Belonogaster, Mischocyttarus, Parapolybia, and Independent- founding Ropalidia, p. 149-190. In: Ross, K. G. \& Matthews, R. W. (eds.). The Social Biology of Wasps, Ithaca, Cornell University Press, 678 p.

Garcete-Barrett, B. R. 1999. Guía ilustrada de las avispas sociales del Paraguay (Hymenoptera: Vespidae: Polistinae). London, The Natural History Museum, $44 \mathrm{p}$.

Giannotti, E. 1998. The colony cycle of the social wasp Mischocyttarus cerberus styx Richards, 1940 (Hymenoptera, Vespidae). Revista Brasileira de Entomologia 41: 217-224.

Giannotti, E. 1999. Social organization of the eusocial wasp Mischocyttarus cerberus styx (Hymenoptera, Vespidae). Sociobiology 33: 325-338.

Giannotti, E. \& Fieri, S. R. 1991. On the brood of Mischocyttarus (Monocyttarus) cassununga (Iheringi, 1903) (Hymenoptera, Vespidae). Revista Brasileira de Entomologia 35: 263-267.

Giannotti, E. \& Silva, C. V. 1993. Mischocyttarus cassununga (Hymenoptera, Vespidae): external morphology of the brood during the post-embrionic development. Revista Brasileira de Entomologia 37: 309-312.

Goloboff, P. A. 1993a. Estimating character weights during tree search. Cladistics 9: 83-91.

Goloboff, P. A. 1993b. Nona: A tree searching program. Program and documentation available at http://www.zmuc.dk/public/ phylogeny.

Goloboff, P. A. 1997. Self-Weighted Optimization: Tree Searches and Character State Reconstructions under Implied Transformation Costs. Cladistics 13: 225-245.

Goloboff, P. A. \& J. S. Farris. 2001. Methods for quick consensus estimation. Cladistics 17: 526-534.

Goloboff, P. A.; J. S. Farris \& K. C. Nixon. 2005. T.N.T. Tree Analysis Using New Technology. Program and documentation, available at http://www.zmuc.dk/public/phylogeny.

Gorton, E. T. Jr. 1978. Observation on the nesting behavior of Mischocyttarus immarginatus (Rich.) (Vespidae: Hymenoptera) in a dry forest in Costa Rica. Insectes Sociaux 25: 197-204.

Goulet, H. \& J. T. Huber. 1993. Hymenoptera of the World: an identification guide to families. Research Branch Agriculture Canada, $509 \mathrm{p}$

Hunt, J. H. 1991. Nourishment and the evolution of the social Vespidae, p. 426-450. In: Ross, K. G. \& Matthews, R. W. (eds.). The Social Biology of Wasps, Ithaca, Cornell University Press, 678 p.

Jeanne, R. L. 1970. Chemical defense of brood by a social wasp. Science 168: $1465-1466$

Jeanne, R. L. 1972. Social biology of the Neotropical wasp Mischocyttarus drewseni. Bulletin of the Museum of Comparative Zoology of Harvard University 144: 63-150.

Jeanne, R. L. 1980. Evolution of social behavior in the Vespidae. Annual Review of Entomology 25: 371-396.

Kojima, J. 1982. Taxonomic revision of the subgenus Icarielia of the genus Ropalidia (Vespidae) in the Philippines. Kontyû 50: 108124.

Kojima, J. 1984. Ropalidia wasps in the Philippines (Hymenoptera, Vespidae). (I) Subgenus Icariola. Kontyû 52: 522-532.

Kojima, J. 1998. Larvae of social wasps (Insecta: Hymenoptera; Vespidae). Natural History Bulletin of the Ibaraki University 2: 7-227

Kojima, J. \& K. Kojima. 1988. Three new species of Polistes Latreille (Hymenoptera: Vespidae) from Papua New Guinea, with notes on the taxonomic status of the subgenus Stenopolistes van der Vecht. Journal of the Australian Entomological Society 27: 69-80.
Litte, M. 1977. Behavioral ecology of the social wasp, Mischocyttarus mexicanus. Behavioral Ecology and Sociobiology 2: 229-246.

Litte, M. 1979. Mischocyttarus flavitarsis in Arizona: social and nesting biology of a polistine wasp. Zeitschrift fur Tierpsychologie 50: $282-312$.

Litte, M. 1981. Social biology of the polistine wasp Mischocyttarus labiatus: survival in a Colombian rain forest. Smithsonian Contributions of Zoology 327: 1-27.

London, K. B. \& R. L. Jeanne. 1996. Alarm in a wasp-wasp nesting association: do members signal cross-specifically?. Insectes Sociaux 43: 211-215.

Machado, V. L. L. \& F. M. Wiendl. 1976. Aspectos do comportamento de colônias de Mischocyttarus cassununga von Ihering, tratadas com alimento marcado por radiofósforo. Anais da Sociedade Entomológica do Brasil 5: 78-85.

Melo, G. A. R. 1999. Phylogenetic Relationships and Classification of the Major Lineages of Apoidea (Hymenoptera), with emphasis on the Crabronid Wasps. Scientific Papers (Natural History Museum of the University of Kansas) 14: 1-55.

Nixon, K. C. 2002. WinClada ver. 1.00.08 Published by the author, Ithaca, NY. Available at http://www.cladistics.com/about winc.htm

Nixon, K. C. \& Davis, J. I. 1991. Polymorphic taxa, missing values and cladistic analysis. Cladistics 7: 233-241.

O’Donnell, S. 1992. Gastral rubbing observed in Mischocyttarus immarginatus (Hymenoptera: Vespidae) in Costa Rica. Sphecos 23: 5

O'Donnell, S. 1999. The function of male dominance in the eusocial wasp Mischocyttarus mastigophorus (Hymenoptera: Vespidae). Ethology 105: 273-282.

Queller, D. C.; J. E. Strassmann \& C. R. Hughes. 1992. genetic relatedness and population structure in primitively eusocial wasps in the genus Mischocyttarus (Hymenoptera: Vespidae). Journal of Hymenopterological Research 1: 81-89.

Rapôso-Filho, J. R. 1987. Atividades dos machos de Mischocyttarus (Monocyttarus) extinctus Zikán, 1935 (Vespidae - Polistinae). Boletim do Instituto de Ciências Biológicas e Geociências, Juiz de Fora 40: 17-23.

Rapôso-Filho, J. R. 1989. Comportamento de defesa e agregação das colônias de Mischocyttarus extinctus Zikán, 1935 (Vespidae Polistinae). Boletim do Instituto de Ciências Biológicas e Geociências, Juiz de Fora 42: 37-43.

Rapôso-Filho, J. R.; C. Calloni \& G. Delfino. 1994. Structural and ultrastructural features of the glands in the VI and VII gastral sternites of female Mischocyttarus (Kappa) atramentarius Zikán 1949 (Hymenoptera Vespidae). Ethology Ecology \& Evolution, Special issue 3: 47-52.

Rapôso-Filho, J. R. \& V. M. Rodrigues. 1984a. Vespídeos sociais: condição dos ovaríolos durante o ciclo de desenvolvimento das colônias de Mischocyttarus (Monocyttarus) extinctus Zikán, 1935 (Vespidae, Polistinae, Polybiini). Revista Brasileira de Entomologia 28: 295-300.

Rapôso-Filho, J. R. \& V. M. Rodrigues. 1984b. Habitat e local de nidificação de Mischocyttarus (Monocyttarus) extinctus Zikán, 1935 (Polistinae - Vespidae). Anais da Sociedade Entomológica do Brasil 13: 19-28

Rapôso-Filho, J. R. \& V. M. Rodrigues. 1986. O órgão de van der Vecht em Mischocyttarus extinctus Zikán (Polistinae, Vespidae) Naturalia, São Paulo, 11/12: 107-116.

Rapôso-Filho, J. R. \& V. M. Rodrigues. 1987. O comportamento de "mouthing"de Mischocyttarus (Monocyttarus) extinctus Zikán, 1935 (Vespidae - Polistinae). Boletim do Instituto de Ciências Biológicas e Geociências, Juiz de Fora 40: 11-16.

Rapôso-Filho, J. R. \& V. M. Rodrigues. 1988. Comportamento de corte da dominante pelas não-operárias de Mischocyttarus (Monocyttarus) extinctus Zikán, 1935 (Polistinae - Vespidae). Boletim do Instituto de Ciências Biológicas e Geociências, Juiz de Fora 41: 3946.

Raw, A. 1985. Two new species of Mischocyttarus (Vespidae, Hymenoptera) from Brazil. Revista Brasileira de Entomologia 29: 107-112. 
Raw, A. 1996. Mischocyttarus (Monocyttarus) mamirauae, a new species of social wasp (Hymenoptera, Vespidae) from flooded Amazon forest. Boletim do Museu Paraense Emílio Goeldi (nova série), Zoologia 12: 3-8.

Reid, J. A. 1942. On the classification of the larvae of the Vespidae. Transactions of the Royal Entomological Society, London 93: $285-331$.

Richards, O. W. 1940. Preliminary diagnoses of some new species of Mischocyttarus Saussure (Hymenopt., Vespidae). Annals and Magazine of Natural History 5: 176-183.

Richards, O. W. 1941. The classification of the genus Mischocyttarus Saussure (Hymenopt., Vespidae). Proceedings of the Royal Entomological Society, London (B) 10: 124-130.

Richards, O. W. 1945. A revision of the genus Mischocyttarus de Saussure (Hymen., Vespidae). Transactions of the Royal Entomological Society, London 95: 295-462.

Richards, O. W. 1971. The biology of the social wasps ( Hymenoptera, Vespidae). Biological Review (Cambridge) 46: 483-528.

Richards, O. W. 1973. The subgenera of Polistes Latreille (Hymenoptera, Vespidae). Revista Brasileira de Entomologia 17: $85-103$.

Richards, O. W. 1978. The social wasps of the Americas excluding the Vespinae. London, British Museum (Natural History), $580 \mathrm{p}$.

Saussure, H. F. de. 1853-1858. Études sur la familie des Vespides. 2. Monographie des guêpes sociales, ou de la tribu des Vespiens. Paris: Masson, and Geneva: J. Cherbuliez.

Silva, M. N. 1988. Análises morfométricas em adultos de Mischocyttarus (Kappa) atramentarius Zikán, 1949 (Hymenoptera - Vespidae). Boletim do Instituto de Ciências Biológicas e Geociências, Juiz de Fora 41: 29-38.

Silva, M. N. \& Oliveira, S. M. do C. 1989. Variação no tamanho do corpo e no desenvolvimento de Mischocyttarus atramentarius (Hymenoptera, Vespidae), durante o ciclo de desenvolvimento das colônias. Boletim do Instituto de Ciências Biológicas e Geociências, Juiz de Fora 42: 25-36.

Silva, M. N. \& V. M. Rodrigues. 1987. Observações sobre a proximidade de nidificação de duas vespas sociais neotropicais. Boletim do Instituto de Ciências Biológicas e Geociências, Juiz de Fora 40: $25-34$.

Silveira, O. T. 1998. Mischocyttarus (Mischocyttarus) aripuanaensis. A new social wasp from western-central Brazil, and redescription of Mischocyttarus lindigi Richards (Hym., Vespidae, Polistinae). Papéis Avulsos de Zoologia, S. Paulo 40: 359-367.

Silveira, O. T. 2002. Mischocyttarus acunai Alayo: A Caribbean member of the subgenus Mischocyttarus s. str. de Saussure (Hymenoptera: Vespidae; Polistinae). Natural History Bulletin of Ibaraki University 6: 7-10.

Silveira, O. T. 2004. The male of Mischocyttarus nomurae Richards, with a re-examination of the limits and contents of the $M$. cerberus species group (Hymenoptera, Vespidae, Polistinae, Mischocyttarini). Revista Brasileira de Entomologia 48: 335338 .

Silveira, O. T. 2006. Revision of the subgenus Kappa de Saussure of Mischocyttarus de Saussure (Hym.; Vespidae, Polistinae, Mischocyttarini). Zootaxa 1321: 1-108.

Starr, C. K. 1988. The nesting association of the social wasps Mischocyttarus immarginatus and Polybia spp. in Costa Rica. Biotropica 20: 171-173.

Strassmann, J. E.; D. C. Queller \& C. R. Solis. 1995. Genetic relatedness and population structure in the social wasp, Mischocyttarus mexicanus (Hymenoptera: Vespidae). Insectes Sociaux 42: 379383.

Wenzel, J. W. 1998. A generic key to the nest of hornets, yellowjackets, and paper wasps worldwide (Vespidae: Vespinae, Polistinae). American Museum Novitates 3224: 1-39.

Wenzel, J.W. 1991. Evolution of nest architecture, p. 480-519. In: Ross, K. G. \& Matthews, R. W. (eds.). The Social Biology of Wasps, Ithaca, Cornell University Press, 678p.

Wenzel, J. W. \& J. M. Carpenter. 1994. Comparing methods: adaptive traits and tests of adaptation, p. 79-101. In: Eggleton, P. \& VaneWright, R. I. (eds.). Phylogenetics and Ecology, London, Academic Press, $378 \mathrm{p}$.

Wilkinson M. 1995. A comparison of two methods of character construction. Cladistics 11: 297-308.

Windsor, D. M. 1972. Nesting association between two neotropical Polybiine wasps (Hymenoptera, Vespidae). Biotropica 4: 1-3.

Zikán, J. F. 1935. Die sozialen Wespen der Gattung Mischocyttarus Saussure, nebst Beschreibung 27 neuen Arten (Hym., Vespidae). Arquivos do Instituto de Biologia Vegetal, Rio de Janeiro 1: 143-203.

Zikán, J. F. 1949. O gênero Mischocyttarus Saussure (Hymenoptera, Vespidae), com a descrição de 82 espécies novas. Boletim do Parque Nacional do Itatiaia 1: 1-125. 